\title{
Moving Ahead with REDD Issues, Options and Implications
}

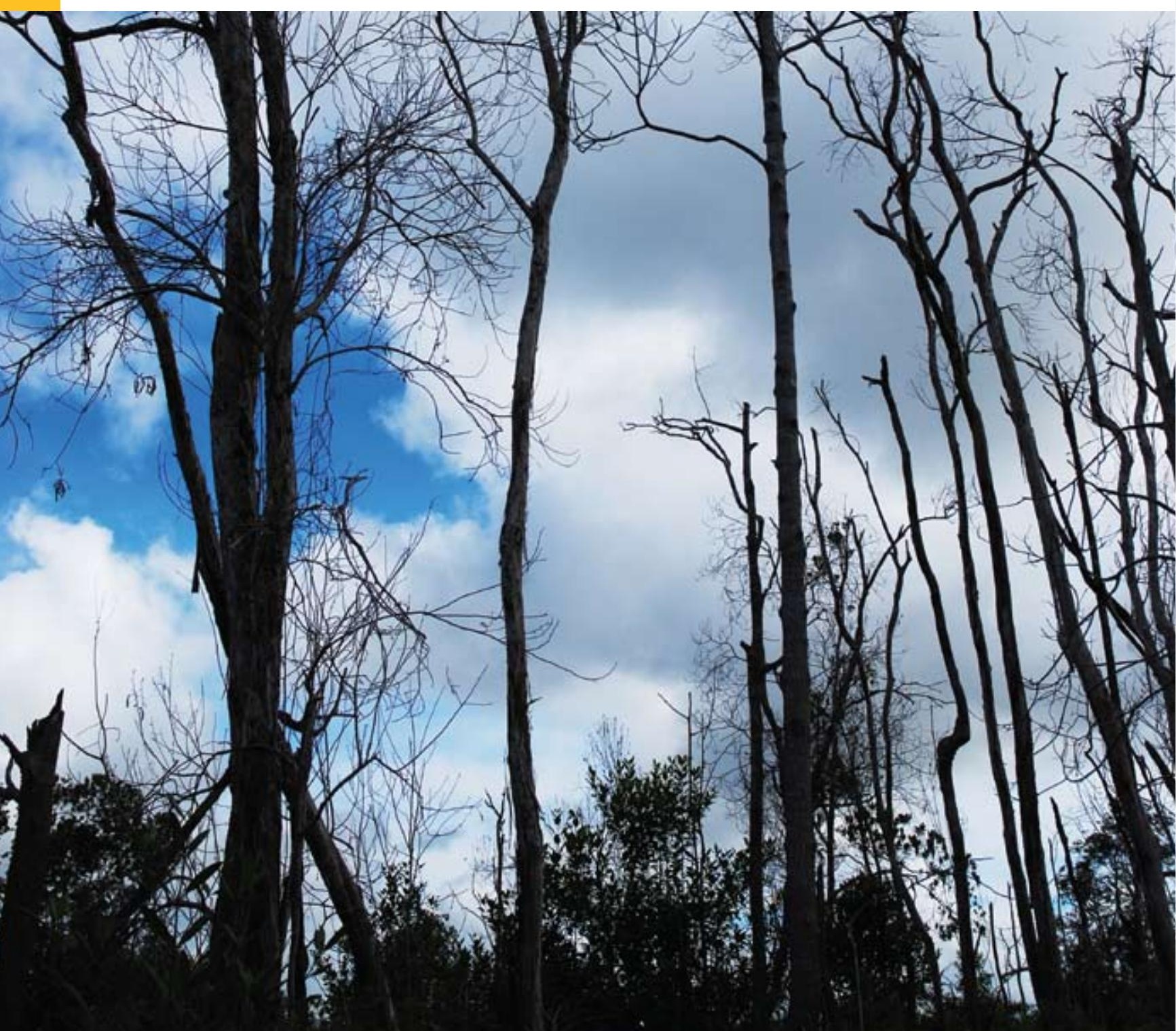





\section{Moving Ahead with REDD Issues, Options and Implications}

Edited by Arild Angelsen 


\section{Disclaimer}

Any views expressed in this book are those of the authors. They do not necessarily represent the views of the authors' institutions or the financial sponsors of this book.

Angelsen, A. (ed.) 2008 Moving ahead with REDD: Issues, options and implications.

CIFOR, Bogor, Indonesia.

Photo credits: Book cover, Chapter 3, 7 \& 8: Ryan Woo, Chapter 1 \& 4: Brian Belcher, Chapter 2: Herwasono Soedjito, Chapter 5: Christophe Kuhn, Chapter 6: Markku Kanninen, Chapter 9: Carol J.P. Colfer, Chapter 10: Agung Prasetyo, Chapter 11: Edmond Dounias.

Printed by SUBUR Printing, Indonesia

$156 \mathrm{p}$.

ISBN 978-979-1412-76-6

Published by Center for International Forestry Research

J. CIFOR, Situ Gede,

Bogor Barat 16115, Indonesia

Tel.: +62 (251) 8622-622; Fax: +62 (251) 8622-100

E-mail: cifor@cgiar.org

Web site: http://www.cifor.cgiar.org

\section{(C) by CIFOR}

All rights reserved.

Published in 2008

\section{Center for International Forestry Research (CIFOR)}

CIFOR advances human wellbeing, environmental conservation, and equity by conducting research to inform policies and practices that affect forests in developing countries. CIFOR is one of 15 centres within the Consultative Group on International Agricultural Research (CGIAR). CIFOR's headquarters are in Bogor, Indonesia. It also has offices in Asia, Africa and South America. CIFOR works in over 30 countries worldwide and has links with researchers in 50 international, regional and national organisations. 


\section{Contents}

Preface

iv

vi

vii

xi

1

1 What is this book about?

Arild Angelsen and Stibniati Atmadja

2 What are the key design issues for REDD and the criteria for assessing options?

Arild Angelsen and Sheila Wertz-Kanounnikoff

3 What are the costs and potentials of REDD?

Ruben Lubowski

4 What is the right scale for REDD?

Arild Angelsen, Charlotte Streck, Leo Peskett, Jessica Brown and Cecilia Luttrell

Michael Dutschke and Sheila Wertz-Kanounnikoff

With Leo Peskett, Cecilia Luttrell, Charlotte Streck and Jessica Brown

6 How do we set the reference levels for REDD payments?

Arild Angelsen

7 How do we deal with leakage?

Sven Wunder

8 How do we ensure permanence and assign liability?

Michael Dutschke

With Arild Angelsen

9 How do we monitor, report and verify carbon emissions from forests?

Sheila Wertz-Kanounnikoff and Louis V. Verchot

With Markku Kanninen and Daniel Murdiyarso

10 How do we measure and monitor forest degradation?

Daniel Murdiyarso, Margaret Skutsch, Manuel Guariguata,

Markku Kanninen, Cecilia Luttrell, Pita Verweij and Osvaldo Stella Martins

11 How do we achieve REDD co-benefits and avoid doing harm?

David Brown, Frances Seymour and Leo Peskett

Appendix: Overview of REDD proposals submitted to the UNFCCC

Philippe Guizol and Stibniati Atmadja

Abbreviations

Glossary

References 


\section{Preface}

Emissions from deforestation and forest degradation in developing countries constitute some 20 percent of the total global emission of greenhouse gases annually. These large emissions are not included today under the United Nations Framework Convention on Climate Change (UNFCCC) or its Kyoto Protocol.

If we are to be serious in our efforts to combat climate change and limit the rise in global temperature to no more than $2^{\circ} \mathrm{C}$, reducing emissions from deforestation and forest degradation (REDD) in developing countries must be included in the next global climate regime.

REDD has the potential to generate substantial benefits in addition to the reduction of greenhouse gas emissions. These include positive impacts on biodiversity and on sustainable development, including poverty reduction and strengthening indigenous peoples' rights. Thus, if designed properly, REDD may produce a triple dividend - gains for the climate, for biodiversity and for sustainable development.

At the Thirteenth Session of the Conference of Parties in Bali in December 2007, Norway launched its International Climate and Forest Initiative. Through this initiative, Norway is prepared to allocate up to NOK 3 billion a year to REDD efforts in developing countries over the next 5 years. The contributions from Norway and other donor countries, as well as multilateral agencies, must be seen as demonstrations of sincere interest and commitment to contribute towards reduced emissions from deforestation and forest degradation in developing countries.

It will, however, be possible to achieve large-scale and sustainable reductions in greenhouse gas emissions from deforestation and forest degradation in developing countries only if these emissions are included in a global post-2012 climate regime. 
While the underlying idea of REDD is simple, there are complex issues to be solved, such as measurement, scale, funding, permanence, liability, leakage and reference levels. Norway has supported the production of this book with the aim to facilitate progress of the UNFCCC negotiations on these complex issues by clarifying options associated with each issue - and especially their implications for effectiveness, efficiency and equity.

With strong political will from all parties, it is our hope and ambition that REDD can be included in the next climate agreement in a way that yields the triple dividend.

Erik Solheim

Minister of Environment and International Development

Norway 


\section{Acknowledgements}

This book has been produced in just two months thanks to the enthusiasm and hard work of more than three dozen people.

The authors worked long hours to write the text, and made several revisions in response to internal and external reviews. Most authors also peer-reviewed other chapters.

Four of the chapters $(3,4,5$ and 10) are based on papers and Infobriefs prepared under a joint CIFOR-IPAM-ODI project, coordinated by Cecilia Luttrell. Cecilia pushed the work forward, provided significant intellectual contributions and did a very thorough job of editing those chapters.

At the CIFOR headquarter in Bogor, Stibniati ('Nia') Atmadja coordinated the publication process, proofread and edited chapters, and provided vital inputs to various parts of the book, such as the overview of UNFCCC submissions and glossary.

A number of other people at CIFOR have also been involved. Manuel Guariguata arranged for the external review. Sandra McGuire put the weight of the communications department at CIFOR behind this endeavor. Gideon Suharyanto took the lead in ensuring the book meets CIFOR's printing standards. Rahadian Danil did most of the typesetting and graphics design, while Catur Wahyu helped improve many of the figures.

David Kaimowitz and Robert O'Sullivan, the external book reviewers, gave critical and invaluable comments and suggestions. In addition to the authors of the chapters, a number of other people reviewed or contributed to one or more chapters: Laura Bozzi, Andrea Cattaneo, Joz Cozijnsen, Karsten Dunger, Manuel Estrada, Annette Frieberg, Alana George, Ole Hofstad, Dimitri Kanounnikoff, Katia Karousakis, Patrick van Laake, Michael Obersteiner, Krystof Obidzinski, Lucio Pedroni, Herry Purnomo, Paulo Moutinho, Stephan Schwartzmann, Fred Stolle and Dan Zarin. All chapters were thoroughly edited by Sandra Child, Mark Havard, Guy Manners, Claire Miller, Henning Pape-Santos and Catharine Way. 
The International Climate and Forest Initiative of the Government of Norway sponsored production of the book. The joint CIFOR-IPAM-ODI project was funded by The David and Lucile Packard Foundation.

This book is the result of solid team work. To all the individuals and institutions that have contributed: terima kasih and tusen takk!

Bogor, Indonesia and Ås, Norway, 30 November 2008

Arild Angelsen

(Editor) 


\section{Summary}

Reducing emissions from deforestation and forest degradation (REDD) is based on a core idea: reward individuals, communities, projects and countries that reduce greenhouse gas (GHG) emissions from forests. REDD has the potential to deliver large cuts in emissions at a low cost within a short time frame and, at the same time, contribute to reducing poverty and sustainable development.

This sounds too good to be true. REDD is based on a simple and appealing idea, but turning the idea into action is much more complex. We must address many difficult questions before we can create mechanisms that fully exploit the potential of REDD: How can we measure reductions in emissions when data are poor or do not exist? How can we raise the billions of dollars needed to put a REDD mechanism in place? How can we make sure that any reductions in deforestation and degradation are real (additional), and that they do not lead to more trees being chopped down in other forest areas (leakage) or next year (permanence)? How can we make sure that the poor benefit?

This book discusses these questions. They are highly relevant to the design of the global REDD architecture in the post-2012 climate regime that is currently being negotiated under the United Nations Framework Convention for Climate Change (UNFCCC). Each chapter deals with a key issue, presents the options and assesses the implications according to the ' $3 \mathrm{E}$ ' criteria: carbon effectiveness, cost efficiency, and equity and co-benefits. While there are technical solutions to all the problems, there are sometimes tradeoffs between the 3Es. Moreover, there are few purely technical issues; most options have political implications, for example, on the distribution of REDD funds across countries.

REDD will require unprecedented levels of funding to achieve emissions reductions of, say, 50 percent. Public funding, including development aid, is needed for capacity building (readiness), demonstration activities, policy reforms and for activities in high-risk regions with weak governance. Tapping into carbon markets, however, has the potential to raise even larger amounts of funds. This funding might be generated by selling REDD credits directly in compliance markets, or from funds generated by auctioning of emission allowances or from a tax on carbon trade. 
Some fear the risk of 'market flooding' and 'crowding out' of other mitigation efforts if (cheap) REDD credits are made fungible (interchangeable) with other types of carbon credits. These fears may be overstated and there are options to minimise the risks. In particular, if REDD is included in a global agreement overall GHG emission targets could be more ambitious without raising overall costs. This means the UNFCCC negotiations must not separate decisions about overall targets from decisions on how to include REDD.

The impact of integrating REDD credits into the carbon market also depends on the supply of credits. This, in turn, is influenced by emissions crediting baselines (reference levels). Among the issues being debated in REDD, the argument about reference levels is among the most contentious. Reference levels have huge implications for both the effectiveness of REDD and equity across countries. Negotiators face a dilemma. They have to balance the risk of 'tropical hot air' and diluted incentives if baselines are too generous; and low participation and rejection by developing countries if baselines are set too tight.

For a REDD mechanism to be effective, emissions reductions must be additional, that is, emissions reference levels must not be set above the business-as-usual scenario. Further, the emission reductions must be permanent. Assigning liability in the case of non-permanence is necessary if REDD credits are to be made fungible (interchangeable) with carbon credits from other sectors.

While non-permanence is a form of temporal leakage, spatial leakage occurs if reducing deforestation and degradation in one geographical area leads to higher emissions in another. Domestic leakage can be monitored and possibly also reduced by redesigning interventions, neutralising activities, or moving up to a higher geographical scale of accounting and crediting.

There are three main approaches for the geographical scale of REDD accounting and international crediting: the subnational, the national, or a combination of the two in a nested approach. A national approach accounts for domestic leakage, and stimulates countries to make broad-based (and sometimes cheap) policy reforms that can lead to deeper and more permanent reductions in emissions. The subnational approaches, such as projects, are attractive to private investors because outputs are more tangible, and can work in countries that are not institutionally ready to implement a national approach. A nested approach allows countries to start with a subnational approach and to scale up to a national approach over time, or to simultaneously account and receive credits at both the subnational and national levels. The nested approach, therefore, is more flexible and allows more countries to take part in REDD.

The capacity to monitor, report and verify (MRV) emissions, vary considerably across countries. A global REDD scheme must be flexible enough to avoid discriminating against countries with low MRV capacity. The guidelines of 
the International Panel on Climate Change (IPCC) allow for a soft entry, for example, permitting countries to use global default values for carbon stocks per hectare in emission accounting. This kind of flexibility would allow poor countries with high levels of degradation to be included. But, the uncertainties inherent in these simpler approaches mean that credits would need to be 'discounted'. This creates a direct incentive for countries to upgrade their measuring and monitoring methods so that they can get full credits.

REDD has the potential to achieve significant co-benefits, including alleviating poverty, improving governance, and conserving biodiversity and providing other environmental services. While co-benefits are largely determined by national REDD strategies and the way countries implement them (which are beyond the scope of this book), the global REDD architecture should provide - and not foreclose on- opportunities for developing countries to implement REDD in ways that deliver co-benefits without doing harm. REDD financial flows and national implementation need to be harmonised with pre-existing international commitments and emerging norms, especially procedural safeguards, to minimise the risk of unintended negative consequences for vulnerable communities.

This book highlights the fact that countries differ widely in terms of their MRV infrastructure, institutional capacity to implement REDD policies and measures, drivers of deforestation and forest degradation, and so on. This heterogeneity needs to be reflected in the global REDD architecture. The mechanisms must be flexible enough to ensure broad country participation from the beginning. At the same time, they should also include incentives 'to move on', for example, to improve MRV and to graduate from a subnational (project) approach to a national approach. Flexibility is also needed for another reason: REDD is a large-scale experiment and we need to leave room for midcourse corrections as we learn what works and what does not. 


\section{List of Authors}

Arild Angelsen - Senior Associate, Center for International Forestry Research (CIFOR), Indonesia and Professor, Norwegian University of Life Sciences (UMB), Norway - arild.angelsen@umb.no

Stibniati Atmadja - Research Fellow, Center for International Forestry Research (CIFOR), Indonesia - s.atmadja@cgiar.org

David Brown - Research Fellow, Overseas Development Institute (ODI), UK -d.brown@odi.org.uk

Jessica Brown - Research Officer, Overseas Development Institute (ODI), UK-j.brown@odi.org.uk

Michael Dutschke - Managing Director, Biocarbon Consult, Germany michael@biocarbon.net

Manuel Guariguata - Principal Scientist, Center for International Forestry Research (CIFOR), Indonesia-m.guariguata@cgiar.org

Phillippe Guizol - Research Scientist, French Agricultural Research Centre for International Development (CIRAD), France and Center for International Forestry Research, Indonesia-p.guizol@cgiar.org

Markku Kanninen - Principal Scientist, Center for International Forestry Research (CIFOR), Indonesia - m.kanninen@cgiar.org

Ruben Lubowski - Senior Economist, Environmental Defense Fund, USA rlubowski@edf.org

Cecilia Luttrell - Associate Researcher, Center for International Forestry Research (CIFOR), Indonesia - c.luttrell@cgiar.org

Daniel Murdiyarso - Principal Scientist, Center for International Forestry Research (CIFOR), Indonesia - d.murdiyarso@cgiar.org

Leo Peskett - Research Fellow, Overseas Development Institute (ODI), UK - l.peskett@odi.org.uk

Frances Seymour - Director General, Center for International Forestry Research (CIFOR), Indonesia-f.seymour@cgiar.org

Margaret Skutsch - Senior Researcher, University of Twente, Netherlands m.skutsch@utwente.nl

Osvaldo Stella Martins - Programme coordinator, Instituto de Pesquisa Ambiental da Amazônia (IPAM) - osvaldostella@ipam.org.br 
Charlotte Streck - Director, Climate Focus, Netherlands c.streck@climatefocus.com

Louis Verchot - Principal Scientist, Center for International Forestry Research (CIFOR), Indonesia-l.verchot@cgiar.org

Pita Verweij - Assistant Professor, Utrecht University, Netherlands p.a.verweij@uu.nl

Sheila Wertz-Kanounnikoff - Associate Researcher, Center for International Forestry Research (CIFOR), Indonesia - s.wertz-kanounnikoff@cgiar.org

Sven Wunder - Principal Scientist, Center for International Forestry Research (CIFOR), Indonesia - s.wunder@cgiar.org 


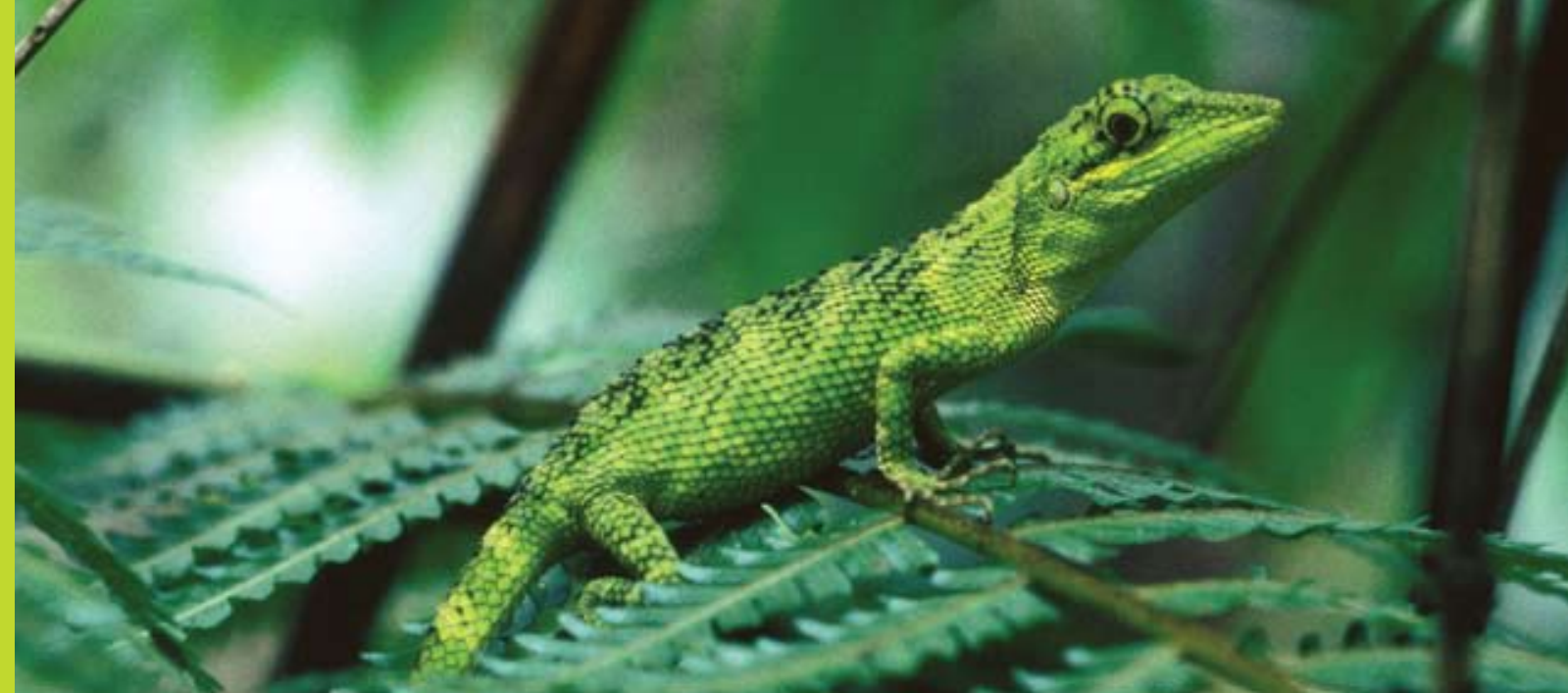

\title{
Chapter 1
}

\section{What is this book about?}

\author{
Arild Angelsen and Stibniati Atmadja
}

\subsection{REDD: Simple, yet complex}

Reducing emissions from deforestation and forest degradation in developing countries (REDD) has moved to centre stage in the international climate debate over the past three years. It is commonly seen as a significant, cheap, quick and win-win way to reduce greenhouse gas (GHG) emissions; significant because one-fifth of global GHG emissions come from deforestation and forest degradation (DD); cheap because much of the DD is only marginally profitable, so, reducing GHG emissions from forests would be cheaper than most other mitigation measures; quick because large reductions in GHG emissions can be achieved with 'stroke of the pen' reforms and other measures not dependent on technological innovations; and win-win because the potentially large financial transfers and better governance can benefit the poor in developing countries and provide other environmental gains on top of the climate-related benefits.

While the details of these claims can be contested and are discussed in several chapters of this book, most observers agree that REDD is a key mechanism in global efforts to limit climate change. We need to move ahead with REDD. 
In the international climate negotiations, REDD refers to a broad set of approaches and actions to reduce emissions from deforestation and forest degradation. At the core of REDD is, however, a scheme whereby the global community will create mechanisms to reward those who reduce emissions from DD. This will tap into the potential for 'significant, quick, cheap and win-win' GHG emission reductions from reducing deforestation and forest degradation.

REDD is, therefore, based around a simple idea: pay those that reduce DD. But, as with all simple ideas, turning it into action is much more complex. Alongside the enthusiasm, uneasiness is gradually growing concerning the feasibility and potentially negative implications of REDD. Many difficult questions must be addressed if we are to create an effective mechanism: How are emissions reductions to be monitored, reported and verified (MRV) if forest data are poor or do not exist? How should REDD be financed, given that a 50\% cut in emissions may cost USD 20-30 billion per year? Should projects or countries, or both, be rewarded? How can we ensure that any emissions reductions are permanent - that trees saved this year will not be felled next year? How do we avoid leakage - that trees saved within a country or project area do not lead to more trees being chopped down elsewhere? How can we ensure that any credited emission reductions are real, that is, additional to what would happen without REDD? How can we ensure that REDD payments are distributed in an equitable manner and benefit the poor? These and other questions need to be addressed if we are to move ahead with REDD and agree on how REDD is to be included in a post-2012 global climate regime.

\subsection{Moving ahead with REDD}

This book follows a simple recipe: we lay out the key problems, present the options on how to deal with them, and then assess the options based on the ' $3 E$ ' criteria: Effectiveness: can the mechanism bring significant emission reductions? Efficiency: are these reductions achieved at the minimum cost? and Equity: are benefits and costs distributed fairly among and within countries?

The working title of the book was 'REDD - Global Architecture in the New Climate Regime'. This indicates our intention, which is to examine the design options for including REDD in the post-2012 global climate agreement currently being discussed by the United Nations Framework Convention on Climate Change (UNFCCC). We discuss the design and implementation of national and local REDD schemes only to the extent that they are relevant to the global REDD architecture. This does not imply that national and local issues are less important in REDD; rather, that they are so comprehensive and complex that they warrant another book! 
A major objective of the book is to point out that, for all the important issues, there are technical options, although there are sometimes trade offs among the 3Es. But, it is not only the technical issues in REDD that are complex. Some REDD options may, for example, have strong implications for the distribution of benefits and costs across countries. The issue of baselines (reference levels) is a case in point. Baselines have a technical element, namely a realistic prediction of future DD in a business-as-usual scenario. But they also determine the level at which a country should start being credited for emissions reductions, based on the interpretation of principles such as 'common but differentiated responsibilities' and 'relevant national circumstances'. The reference levels will have a big impact on benefits and thus be a political issue.

News articles, reports and statements about REDD are published almost every day. Why write a new book on the topic? First, this book comprehensively covers all the major issues and options on the table in the UNFCCC negotiations. As far as we know, no other book dealing with these is currently available. Second, there has been a proliferation of advocates for particular REDD models, both among the UNFCCC parties (countries) as well as among environmental NGOs, research organisations and think tanks. Our modest aim is to complement such offerings and to provide, as far as possible, an objective assessment of the different options.

\subsection{What this book is about}

This book discusses the design options for REDD in a global climate regime. Each chapter looks at a question that UNFCCC negotiators and others involved in the global REDD debate must address.

\section{What are the key design issues for REDD and the criteria for assessing options? Chapter 2 points to three important design issues. First, how should REDD fit in the overall UNFCCC architecture? Should it be part of a broad post-2012 climate agreement or dealt with under a separate agreement? This, the authors argue, largely depends on another question, namely how REDD should be financed, and - as part of that question - how it should be integrated with carbon markets. If, for example, REDD funding comes from compliance markets (to offset commitments of Annex I countries), then it makes better sense to include REDD in a broad post-2012 agreement.}

Second, should REDD be included in an overall framework for the forest sector, and, if so, should forestry also be included in an overall accounting framework for agriculture, forestry and other land uses (AFOLU)? A key issue is whether afforestation and reforestation (A/R), currently part of the Clean Development Mechanism (CDM) under the Kyoto Protocol, should be merged with REDD in a comprehensive forest sector accounting framework. 
Third, what performance measures should be used? Should the policies and measures (PAMs) that reduce emissions be counted (the input approach) or should we measure the outcomes (the output approach)? If the latter is chosen, should incentives be linked to the absolute levels of forest carbon stocks or to the changes in these stocks (equating to emissions, either positive or negative)? The emissions-based approach is in line with the current focus and accounting architecture of the UNFCCC, and is also the main proposal in current REDD negotiations. The rest of the book, therefore, focuses on this approach.

What are the costs and potentials of REDD? Chapter 3 addresses three key questions in the REDD debate. How much will REDD cost? How will REDD affect the overall strategy for reducing GHG emissions? How will REDD affect the carbon price and efforts to reduce emissions in other sectors? The author argues that REDD offers an immediate opportunity to mitigate a significant source of emissions at a relatively low cost. The cost estimates vary, from USD 7 to 28 billion per year for halving deforestation, but even the high end estimates compare favourably with the cost of most other mitigation options. Because it is low cost and has the potential to quickly reduce emissions, exploiting the REDD potential would lead to a larger global emission reduction at the same overall cost. One study finds that including REDD could reduce global warming by $0.25^{\circ} \mathrm{C}$ at no extra cost.

If REDD carbon credits are made fungible (interchangeable) with other carbon GHG credits, some fear carbon markets will be flooded with cheap REDD credits, suppressing other mitigation activities and long-term development of clean energy technologies. While this is a legitimate concern, some reports, such as Eliasch (2008), suggest that this fear might be overstated. Moreover, there are a number of options that could minimise this risk, including tighter overall targets, managed fungibility and 'banking of credits'.

What is the right scale for REDD? Chapter 4 reviews the three main options for international REDD accounting and crediting: (i) at subnational (or project) level; (ii) at national level; or (iii) at both levels in a nested approach. In a nested approach, countries can start with a subnational approach and scale up to a national approach over time. They may also account and receive credits at both the subnational and national levels simultaneously.

In a national approach, governments can make broad-based (and sometimes cheap) policy reforms, ensure consistency in monitoring reporting, and verifying (MRV), and account for any domestic 'leakage'. This option would also encourage better integration with national development policies and result in stronger country ownership. This option is favoured by most nations. Accounting and crediting at the subnational scale, such as the project level, is more attractive to private investors. They may prefer the tangible nature and limited scope of forest projects, and their more direct relationship with 
emissions reductions. REDD projects can be undertaken even when the host country is not institutionally ready to implement REDD at the national level. The third option; the nested approach, is flexible and allows countries to combine different crediting mechanisms and to approach nationallevel implementation at different speeds. Nested approaches can, therefore, maximise the potential of both subnational and national approaches, although a challenge is to harmonise the two levels.

How do we match country needs with financing sources? Chapter 5 outlines the needs for REDD funding in three areas: (i) up front investments in REDD infrastructure, forest monitoring systems, capacity building and other preparatory and demonstration activities ('readiness' activities); (ii) ongoing costs of implementing national policies and measures (PAM); and (iii) compensation payments to forest owners for forgone profits (opportunity costs).

Official Development Assistance (ODA) and other forms of public funding could be a source of finance for countries with restricted access to REDD global mechanisms. Good examples are rewarding early action and giving credit for PAM. Market-linked mechanisms, such as including REDD credits in the carbon market, auctioning emission allowances, and/or fees and taxes on carbon transactions, are the most promising avenues for raising the overall volume of funding needed to exploit the REDD potential. But, financing shortfalls are likely in (i) the demonstration period for the international REDD mechanism prior to 2012 and (ii) in countries where forest governance is weak and, thus, where the investment environment is high risk. Whatever the scenario, we need to find ways to make up the shortfall in financing from both public and private sources. Above all, a future REDD mechanism should be open to flexible and creative financing approaches, so it can adapt to countries' changing needs and experiences.

How do we set the reference level for REDD payments? Chapter 6 distinguishes between three meanings of the word 'baseline' in the current debate. These are: (i) the historical baseline, that is, the rate of deforestation and degradation (DD) and the resulting GHG emissions over the past x years; (ii) the projected business-as-usual (BAU) scenario, that is, how would emissions from DD evolve without the REDD activity, and (iii) the crediting baseline, that is, the level at which REDD payments should start. A BAU baseline is the benchmark for assessing the impact of REDD measures that were implemented (and ensuring additionality), whereas the crediting baseline is the benchmark for rewarding the country (or project) if emissions are below that level. While BAU baselines can be seen as technical issues, setting crediting baselines is largely a political question.

Almost all submissions use historical deforestation as the point of departure, and most also recommend that 'national circumstances' and 'rewarding early 
action' be taken into account. These principles still have to be put into practice. A key dilemma facing negotiators is that, on the one hand, generous baselines, based on 'country-by-country' assessments that take national circumstances into account, may create 'tropical hot air', which undermines the environmental integrity (overall emissions reductions) and the credibility of REDD. On the other hand, too-tight crediting baselines may make an agreement unacceptable. In short, the balancing act is between the risk of 'tropical hot air' and the participation and political acceptance of REDD countries.

How do we deal with leakage? Chapter 7 discusses one of the key concerns in the REDD debate. How can we ensure that reduced deforestation and degradation (DD) in one geographical area does not lead to more DD and higher emissions in another area? This chapter analyses the leakage of three forest-climate interactions: afforestation/reforestation, set-aside conservation areas and sustainable forest management.

There are a number of ways to deal with leakage or 'displaced emissions'. These include: (i) monitoring what is happening outside the project boundaries; (ii) moving to a higher scale of accounting and crediting, which is indeed one of the main arguments for a national approach vis-à-vis a subnational approach; (iii) discounting credits based on estimates of the extent of the leakage; (iv) redesigning interventions to minimise leakage; and (v) neutralising leakage with complementary activities, such as 'alternative livelihoods' components.

Leakage can therefore be accounted for and incentives can be structured to reduce leakage. At the same time, leakage is a natural part of an economy's ability to adapt. It cannot be entirely eradicated and should not be a deal breaker. In terms of equity and development, leakage may actually indicate a healthy economy, for example if, in response to REDD-induced barriers, production factors migrate to new opportunities and keep welfare losses at a minimum. Recognising trade-offs between carbon mitigation and broader development goals may thus lead us to deliberately accept some leakage and to reprioritise mitigation actions.

How do we ensure permanence and assign liability? Chapter 8 discusses another major concern in the REDD debate. How can we make sure that a forest area saved today will not be destroyed tomorrow? Who should be held liable if that happens? How can REDD contracts and financial mechanisms be designed to ensure permanence? Once liability for terrestrial carbon stocks has been assumed in an area or sector, non-permanence may still be a threat, but will have to be compensated for elsewhere. This may be the case in the future if developing countries assume emissions targets. Before this happens, we need to find interim solutions. 
One aspect of ensuring permanence in projects or countries is managing risks of re-emission. Another aspect also needs to be addressed, however, if REDD mechanisms are to be credited and used for compliance in voluntary or formal (compliance) carbon markets. In this case, some system of commercial liability must be in place. This chapter provides a toolbox of the different liability mechanisms needed for achieving fungibility of carbon credits from land use and other sectors. The most attractive include: (i) project credit buffers (temporary banking of credits); (ii) pooling risk among several projects; (iii) commercial insurance; and (iv) sharing liability in the form of forest compliance partnerships (FCP) between Annex I and non-Annex I countries.

\section{How can we monitor, report, and verify (MRV) carbon emissions from} forests? Chapter 9 reviews forest monitoring technologies and the trade offs between the different methods. There are two main methods for monitoring: (i) the stock-difference approach, which measures forest carbon stocks at different points in time, and (ii) the gain-loss approach, which estimates the net balance of additions and removals from the carbon pool.

There is a trade off between the cost and the accuracy of the methods. In some countries, the need for a high level of precision requires the use of fine-resolution imagery (e.g. to detect forest degradation or small-scale deforestation), imagery repeated over time (e.g. to overcome cloud cover limitations) or imagery that requires significant expertise to process (e.g. analysing radar images), all of which come at a cost. Similarly, ground measurements, crucial to verify and measure carbon stocks, are time consuming and relatively expensive at a large scale, such as a national inventory.

Because the capacity of countries to do MRV is highly variable, a global REDD scheme must be flexible enough to avoid discriminating against countries with poor MRV capacity. A phased approach is recommended to allow for capacity building, to let countries gain experience, and to eventually integrate them into a performance-based payment mechanism in a future climate regime. Incentives should be put in place that encourage more accuracy and efficiency, and provide support for capacity building. To overcome national capacity and cost constraints, the chapter also explores the option of centralised monitoring by an international institution.

How do we measure and monitor forest degradation? Chapter 10 deals with the most difficult of the two Ds when it comes to measurement, but which is too important as a source of GHG emissions to leave out. Forest degradation can be defined as a reduction in carbon per hectare of forest (carbon density). When data are limited, the International Panel on Climate Change (IPCC) suggests that degradation accounting can start at relatively simple levels, monitoring changes in the areas of different forest types but using global default values of carbon densities. Accuracy can then be gradually increased as more national 
and subnational data become available. The uncertainties inherent in simpler approaches mean that credits would need to be 'discounted'. This would be a direct incentive for countries to upgrade their measuring and monitoring methods.

Overcoming the challenges posed by carbon accounting in forest degradation by using the IPCC stock-difference and gain-loss methods, and appropriate tiers (levels of precision), means that forest degradation could be realistically included in a REDD agreement. This would make REDD more effective because it would account for a wider range of forest greenhouse gas emissions. The international equity of the REDD mechanism would also improve because a wider range of countries, many of them in Africa, would be encouraged to participate. It is, therefore, important that decisions on the MRV framework for degradation allow for a diversity of circumstances.

How do we achieve REDD co-benefits and avoid doing harm? Chapter 11 discusses one of the reasons why REDD has claimed substantial attention in international climate negotiations. REDD has the potential to alleviate poverty, protect human rights, improve governance, conserve biodiversity, and provide other environmental services (i.e. co-benefits) as well as reduce GHG emissions. However, REDD also has the potential to generate unintended negative consequences for the poor and powerless if implemented without appropriate safeguards.

This chapter links each co-benefit with specific design features at the global and national levels so that the co-benefits can be achieved without doing harm. The authors suggest that (i) integrating REDD into mainstream economic development strategies is important to ensure REDD financing will benefit the poor; (ii) performance-based payments, data transparency, financial accountability and international scrutiny could exert a positive influence on human rights and governance; and (iii) biodiversity benefits can be enhanced by geographically targeting vulnerable areas, although outcomes also depend on external factors, such as the drivers of deforestation, existing land use strategies and policies that encourage, or prohibit certain types of activities.

The challenge for the international community is to ensure that the global architecture put in place by the UNFCCC provides - and does not foreclose on - opportunities for developing countries to implement REDD in ways that deliver co-benefits without doing harm. Benefits are likely to be greatest and risks minimised if REDD financial flows and national-level implementation are harmonised with other pre-existing international commitments and emerging norms - particularly those related to procedural rights - as well as national development strategies. 
Several chapters point to the very diverse circumstances of different countries in terms of MRV infrastructure, institutional capacity to implement REDD, drivers of deforestation and forest degradation, and so on. This diversity is reflected in national REDD strategies currently being developed in a number of countries. But, the global REDD architecture also needs to reflect this heterogeneity. There is no 'one size fits all'. The mechanisms must be flexible enough to ensure broad participation from the beginning. At the same time, they should also include incentives 'to move on', for example, to improve MRV and to graduate from a subnational (project) to a national level approach.

Flexibility is also needed for another reason; we cannot know for sure how mechanisms will work in practice. Although this book attempts to make some qualified assessments on the implications of various designs, REDD is a largescale experiment. And, 'international negotiation processes are often largescale exercises in learning, through which at least some parties modify their perceptions of the problem and alternative policy options and perhaps see their incentives change as well' (Underdal 2002: 5). Our aim is to contribute to this learning process. 



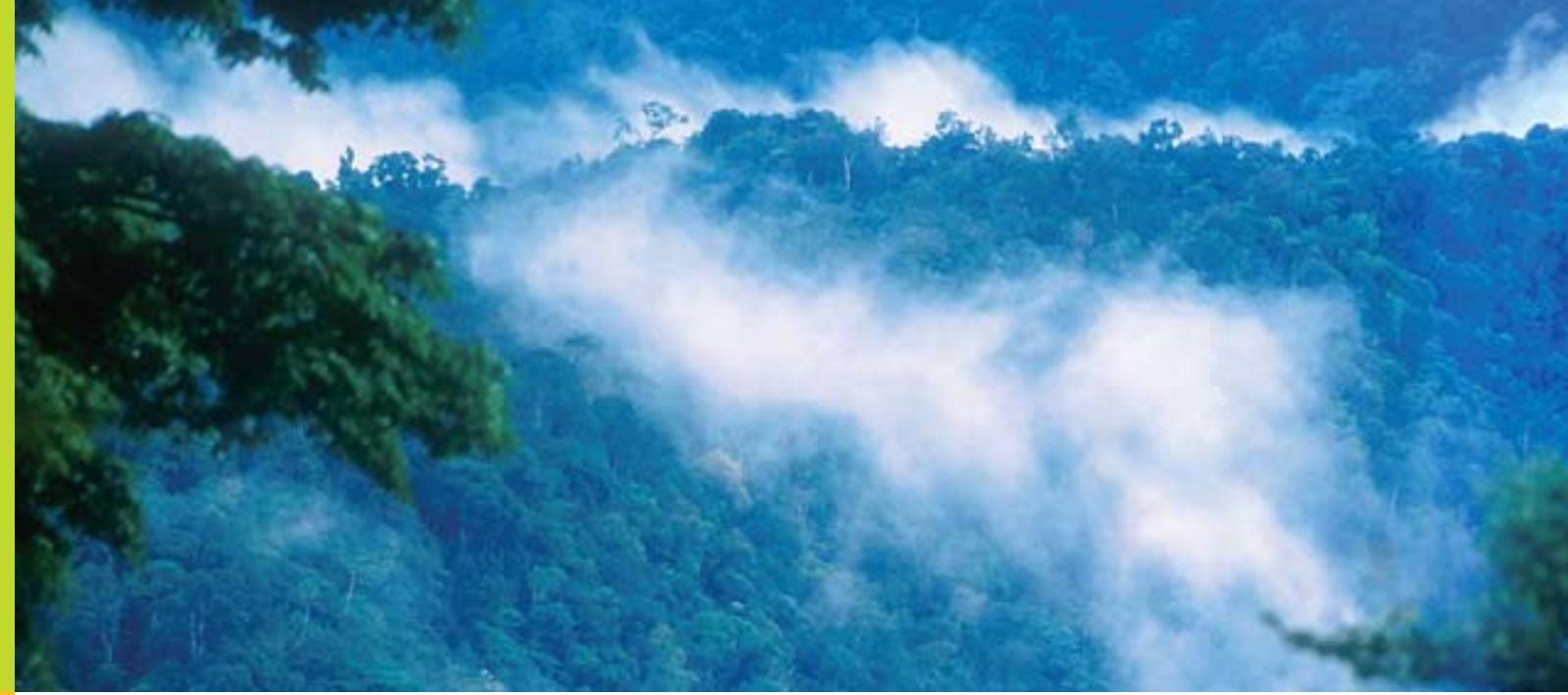

\section{Bhapter 2}

\section{What are the key design issues for REDD and the criteria for assessing options?}

Arild Angelsen and Sheila Wertz-Kanounnikoff

\subsection{What is REDD?}

Reducing Emissions from Deforestation and Forest Degradation in developing countries, or REDD for short, is among the recent additions to the climate vocabulary. Taken literally, REDD is an objective rather than a clearly delimited set of actions or activities. United Nations Framework Convention on Climate Change (UNFCCC) documents refer to REDD as a broad set of approaches and actions that will reduce emissions from deforestation and forest degradation. ${ }^{1}$

In discussions, however, REDD primarily refers to: (i) developing mechanisms to make payments to developing countries for reducing emissions from deforestation and forest degradation (compared with a reference level); and (ii) readiness activities which prepare countries to participate in the REDD

\footnotetext{
1 Note that the abbreviation 'REDD' is used inconsistently in the debate - including UNFCCC documents - as regards the explicit inclusion of 'forest degradation' in the title. The Thirteenth Conference of the Parties (COP 13) in Bali in 2007, for example, refers to it as 'reducing emissions from deforestation in developing countries' (Decision 2/CP.13), whereas the recent submission of views on the Bali Action Plan names REDD as 'reducing emissions from deforestation and forest degradation in developing countries' (FCCC/AWGLCA/2008/18). Yet all explanations share the focus on reducing forest emissions in developing countries.
} 
mechanism. A core issue in REDD is, therefore, to create a multi-level (international and national) 'payments for environmental services (PES)' scheme. This multi-level scheme is illustrated in Figure 2.1.

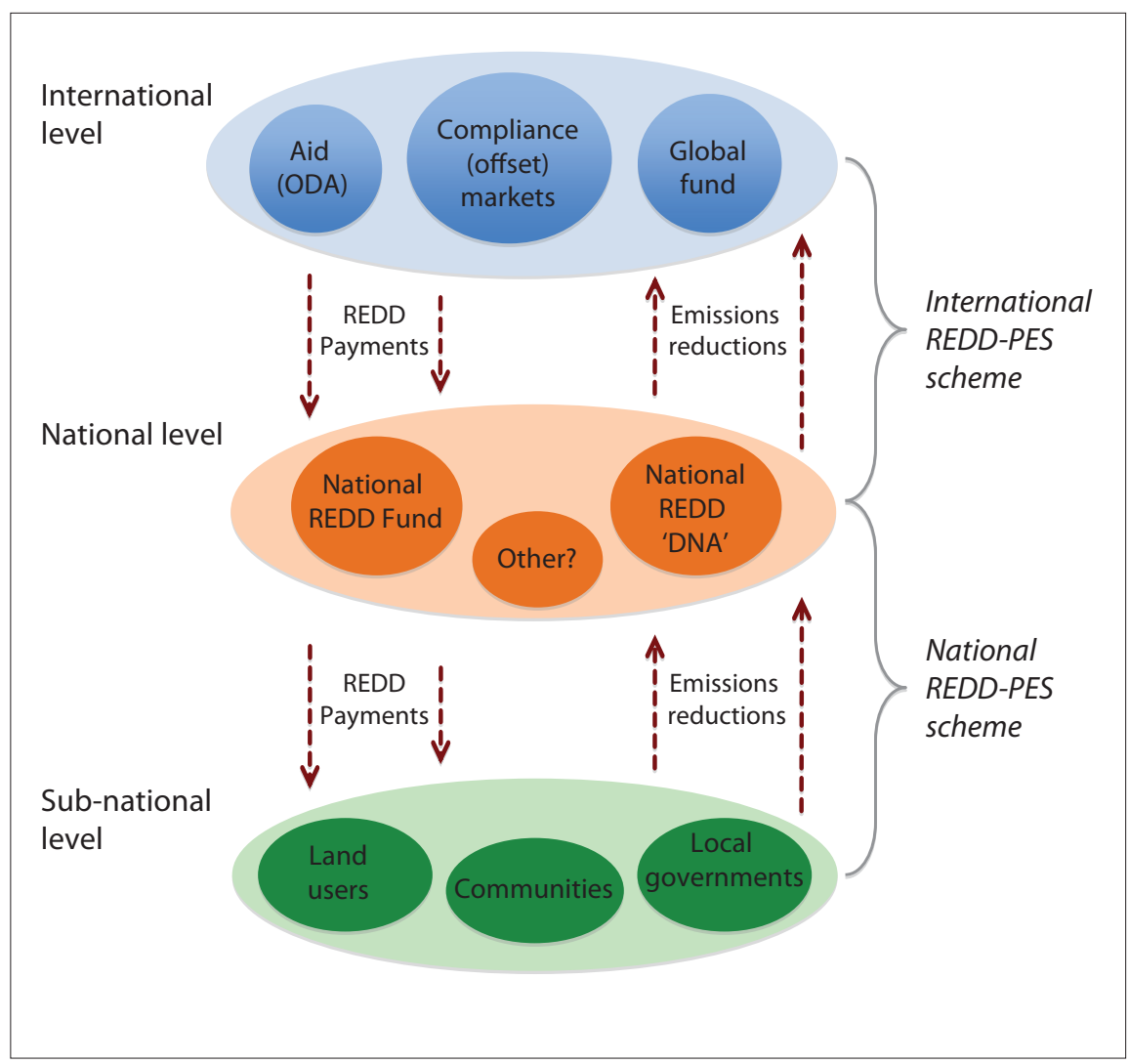

Figure 2.1. Conceptual model of a multi-level REDD 'payments for environmental services' (PES) scheme

At the international level service buyers will make payments (e.g. generated by voluntary or compliance markets) to the service providers (governments or subnational entities in developing countries) for an environmental service (reduced emissions from deforestation and degradation), or measures likely to deliver this service (e.g. tenure reforms, law enforcement). At the country level, national governments or other intermediaries (the service buyers) will pay subnational governments or local land owners (the service providers) to reduce emissions, or take other measures likely to reduce emissions (e.g. reduced impact logging).

Direct payments from international to subnational level are only possible where these transactions are approved by a national government agency - for example, a Designated National Authority (DNA) - as is the case under the current Clean Development Mechanism (CDM) and Joint Implementation 
(JI) under the Kyoto Protocol. However, the current REDD debate largely considers this subnational approach as only an intermediary step towards a national REDD model (Chapter 4).

Importantly, national REDD strategies would - in addition to PES - also include a broad set of policies such as tenure reforms, more effective management of protected forest areas and policies which reduce the demand for forest products and forest land. Indeed, one of the advantages of a national approach is that these broad policies can be put in place and credited to the extent that they result in reduced emissions.

This book focuses on the international level - the design options for a global REDD agreement under the UNFCCC. This chapter discusses some of the overall issues related to design options that are not covered in the other chapters. Three such issues are: (i) where to place REDD within the UNFCCC architecture; (ii) the scope of REDD; and (iii) performance measurement. Finally, we introduce a set of criteria - the triple E criteria (3Es) - to assess design options: carbon Effectiveness, cost Efficiency, and Equity and the co-benefit implications. These criteria are used throughout the subsequent chapters.

\subsection{REDD in the UNFCCC architecture}

One of the critical issues in the REDD debate is whether REDD should: (i) be part of a broader post-2012 regime (cf. submissions by the Coalition for Rainforest Nations, September 2007 and Mexico August 2008); or (ii) be dealt with in a separate agreement (cf. Brazil, February 2007 and Center for Clean Air Policy (CCAP), August 2007). This 'one basket' vs. 'two baskets' perspective may, to some observers, seem like a technical issue, but it relates to several of the fundamental questions in the REDD debate. The most important issue is how REDD should be financed. If REDD funding is (in part) to come from compliance markets, that is if Annex I countries can purchase REDD credits (offsets) as part of their own commitments, then it makes better sense to include REDD in the broader post-2012 regime. If REDD finance is to be fund-based a separate REDD agreement is likely to work better. Hence, the positions in this debate essentially reflect diverging views on REDD financing.

Related to question of financing is the debate about REDD being additional to reductions in other sectors. On this issue, interestingly, both sides are putting forward the same arguments. In general, those arguing in favour of a separate REDD agreement believe that it would ensure additionality. A separate REDD agreement would avoid cheap REDD credits 'flooding' the market and would not displace mitigation efforts in other sectors (see Chapters 3, 4 and 6). Following this line of argument, the best way to ensure additionality would be 
to keep the REDD separate from other commitments to reduce greenhouse gas (GHG) emissions.

Those who argue for including REDD in a broader post-2012 regime table two major arguments. First, REDD needs to be directly linked to the compliance market (i.e. selling REDD credits as offsets). Second, by integrating a low-cost mitigation opportunity (read: REDD) into the broader agreement, the overall GHG emission target can be set higher at no extra overall cost (Chapter 3). This would work best if REDD and the overall GHG targets are negotiated simultaneously. Those favouring this approach can refer to the Clean Development Mechanism (CDM) experience. The mechanics of the CDM were decided in Marrakesh in 2001 (COP 7) after overall targets for reducing GHG emissions had been set in Kyoto in 1997 (COP 3). In consequence, one reason for excluding avoided deforestation from the CDM was that it would not yield any additional reductions in emissions.

The issues of targets and commitments of developing countries are also central to the REDD integration debate. Some foresee a future comprehensive cap and trade (CAT) system that includes all countries and sectors (e.g. Eliasch 2008). Others are sceptical to the idea that developing countries should adopt binding targets, at least in the short term, and fear that including REDD in a comprehensive climate agreement might be a first step towards an all-inclusive cap and trade system. The proposal that developing countries also need to make cuts, but not commit to binding targets until developed countries have led the way by lowering their carbon emissions (Stern 2008), seems a promising avenue for global collective action to mitigate climate change.

The question of how REDD would fit in the UNFCCC framework is important as it relates to many of the fundamental REDD issues. It will affect the level of involvement and commitment of the parties (both on the supply and demand side) and how REDD should be financed. The REDD architecture should follow from an agreement on these issues.

\subsection{Scope of REDD and creditable mitigation activities}

The climate debate is about reducing the concentration of greenhouse gases (GHG) in the atmosphere. Including all sinks and sources can, however, become a daunting task. Instead, the climate negotiations can be seen as a stepwise effort, where mitigation is being brought up for discussion bit by bit in more and more sectors and activities. One of the key questions regarding REDD concerns the scope of creditable mitigation activities, and REDD needs to be viewed in relation to two broad accounting framework options: (i) the 
option to include REDD in an overall framework for the forest sector; and (ii) the option to include forestry in an overall framework of agriculture, forestry and other land uses (AFOLU). We discuss each of these in turn.

The total forest carbon stock at any time is determined by two factors: the total forest area, and the carbon per hectare of forest (carbon density). This means changes can be measured by two factors: area and carbon density. Further, one can differentiate between activities that reduce negative change, and those that enhance positive change. This yields four conceptually different ways of boosting forest carbon stocks, as outlined in Table 2.1. These are deforestation, afforestation/reforestation (A/R), degradation, and restoration/rehabilitation.

Table 2.1. Possible scope of creditable activities in a REDD/forestry mechanism. ${ }^{2}$

\begin{tabular}{lll}
\hline Changes in: & Reduced negative change & Enhanced positive change \\
\hline $\begin{array}{l}\text { Forest area } \\
\text { (hectare) }\end{array}$ & Avoided deforestation & $\begin{array}{l}\text { Afforestation and } \\
\text { reforestation }(\mathrm{A} / \mathrm{R})\end{array}$ \\
$\begin{array}{l}\text { Carbon density } \\
\text { (carbon per } \\
\text { hectare) }\end{array}$ & Avoided degradation & $\begin{array}{l}\text { Forest restoration and } \\
\text { rehabilitation (carbon stock } \\
\text { enhancement) }\end{array}$ \\
\hline
\end{tabular}

The debate on the scope of creditable activities in REDD has evolved significantly over the last three years. Initially, the focus was on 'reducing negative changes', at first only from deforestation (COP-11 in 2005 in Montreal) then also from forest degradation (COP-13 in 2007 in Bali). In Bali, the Parties also agreed to explore options for 'enhancement of forest carbon stocks', that is, to possibly also reward the 'enhanced positive changes' (Table 2.1) through forest restoration/rehabilitation. ${ }^{3}$

Enhancing the carbon stock can be viewed as the positive complement of forest degradation - the latter reducing, the former increasing carbon densities. Similarly, A/R can be seen as the positive complement of deforestation. In both cases, the central element is not only to stop negative changes (deforestation, forest degradation), but to go further and reward additional positive changes (A/R, carbon stock enhancement).

2 Note that even in a system that rewards changes in forest area, one needs to know the carbon densities to calculate the overall carbon benefits. The densities might be assumed to be constant over time, or they can be monitored and accounted for to determine the overall changes in forest carbon (emissions), as is done in $\mathrm{CDM} \mathrm{A} / \mathrm{R}$ and some projects in the voluntary market (see Chapter 10).

3 Par. 11 of Decision 2/CP.13 reads: 'Notes the further consideration, under decision 1/CP.13, of policy approaches and positive incentives on issues relating to reducing emissions from deforestation and forest degradation in developing countries; and the role of conservation, sustainable management of forests and enhancement of forest carbon stocks in developing countries' 
There is a strong logical argument for including REDD in a coherent forestry accounting system that comprises not only reduced negative changes, but also enhanced positive changes. Measures taken to stop negative changes can lead to a restoration of the forest area, that is, higher carbon densities. Why should such positive increases not be rewarded? A similar logic or argument can be applied to area increases. Put simply, a $\mathrm{CO}_{2}$ molecule removed from the atmosphere and stored in a tree is just as good as one not emitted.

One challenge associated with such a comprehensive forestry accounting scheme is that $A / R$ is already part of CDM under the Kyoto Protocol. This could be an argument for excluding A/R from the REDD scheme. But, two strong counter arguments can be tabled. CDM A/R has, for various reasons, been a failure so far; if no major revision is undertaken, excluding $A / R$ from a new REDD agreement means that there will be no effective mechanism for taking care of positive changes in forest area. Further, excluding A/R from the REDD means risking fragmentation of the overall forestry architecture (see below).

Another issue related to where REDD fits in the UNFCCC architecture concerns to what extent forestry should be part of comprehensive agriculture, forestry, and other land uses (AFOLU) terrestrial carbon accounting systems. There are arguments in favour of a comprehensive AFOLU approach (Trines et al. 2006, Terrestrial Carbon Group 2008). Such an approach would treat all parties, and different carbon pools, sectors, and activities, consistently. New issues such as bioenergy could also be tackled within a comprehensive framework. A separate REDD agreement risks fragmenting the framework into separate systems for different land use categories. However, the work towards an integrated AFOLU framework is complicated. A promising avenue might be to address REDD as one building block that can be easily connected to a more comprehensive AFOLU framework in the future.

\subsection{Input, emission and stock-based approaches}

A third key issue in the overall design of REDD relates to the basis for crediting. Should payments be made based on the inputs needed to achieve a specific outcome, or on the actual outcome? These two approaches are referred to as input-based and output-based approaches.

In input-based schemes, payments are conditional on the inputs which are assumed to produce a desired outcome, but where the outcome cannot be measured directly. Such schemes are also referred to as 'policies and measures' (PAM). Examples of PAMs for REDD include reforming land tenure and enforcing forest law. They also include the adoption of land use practices likely to secure a desired outcome, for example, reduced impact logging, e.g. how to. 
In output-based schemes, payments are directly conditional on the outcome. Two types of output-based measures are relevant to the REDD debate: emissions-based and stock-based. In an emissions-based (or flow-based) approach only the net changes in carbon stocks for specific periods are used to calculate credits (see Chapter 9). In a stock-based approach, payments are based on the total carbon stock in a forest during a specific period, that is, the absolute levels, and not the changes (emissions).

From effectiveness and efficiency perspectives, output-based schemes are preferable to input-based approaches as they directly connect payments with the service delivered. However, for output-based approaches the outcome must be measurable - a requirement that is not always feasible. In some situations governance and institutions are not yet sufficiently developed to enable outputbased approaches. In other situations, current methodologies might hinder output-based approaches, such as in the case of forest degradation (see Chapter 10).

An emission-based approach was applied in the Kyoto Protocol, making its application to REDD a natural step. Indeed, the focus on emission is embedded in the REDD acronym. Nevertheless, advocates of a stock-based approach argue that it will likely ensure greater carbon effectiveness (Woods Hole Research Center (WHRC) and Amazon Institute for Environmental Research (IPAM) 2008, Terrestrial Carbon Group 2008) and greater willingness-to-pay in the private sector (Centre for International Sustainable Development Law (CISDL) and Global Public Policy Institute (GPPI) 2007). The proponents also refer to the methodological challenges associated with emissions-based approaches (notably reference levels and leakage control, and equity (to account for previous country efforts in forest conservation).

Although a stock-based approach might avoid some of the tricky issues of an emission-based approach, the emission-based approach has advantages in terms of effectiveness. The emerging global carbon markets trade in emission reductions. Preserving stock cannot in itself generate emission credits, which eliminates the opportunity to tap directly into compliance markets to fund REDD activities. ${ }^{4}$

A general principle of an effective mechanism is to target, as directly as possible, the problem at hand. The emission-based approach does this better than the stock-based or input-based approaches. A major risk of the stockbased approach is that large payments could be made to forest areas that are not under threat, thus 'diluting' the funds available for forest under threat and yielding low additionality.

4 Indirect links can, be created, for example, by auctioning GHG emission quotas or taxes in carbon markets to finance stock based approaches (see Chapter 5). 
The emission-based approach is in line with the current focus and accounting architecture of the UNFCCC, and is also the main proposal on the table in the REDD negotiations. The rest of the book therefore deals with the emissionbased approach.

\subsection{The 3E criteria for assessing options}

A large number of design proposals have been put forward for REDD. How can we evaluate them?

A typical REDD proposal seeks to reduce GHG at a minimum cost, while also contributing to sustainable development. Proposals can be evaluated against this objective on three sets of criteria, the '3E criteria' (Stern 2008): Is the mechanism achieving its GHG emission targets (effectiveness)? Is this target achieved at the minimum cost (efficiency)? What are the distributional implications and co-benefits (equity and co-benefits)?

\subsubsection{Effectiveness}

Effectiveness refers to the magnitude of the emission reductions achieved, that is, the 'carbon effectiveness'. Effectiveness depends on a number of factors, including political feasibility and the degree of commitment from countries to participate and implement REDD mechanisms, but -most importantlyon the design of the REDD model. For emissions to be reduced as much as possible, the REDD model would need both depth (significant reductions) and breadth (cover all significant sources and sinks), and the flexibility and robustness to cover diverse local conditions.

Emission reductions are not observed directly, but are defined as the difference between the emissions with and without REDD. It requires: (i) the measurement of actual emissions with REDD must be accurate and verifiable; and (ii) include a realistic assumption of what would happen without REDD (additionality). Finally, a REDD activity may have undesirable side effects in space (displaced emissions or leakage), in time (permanence), and/or on other mitigation efforts. These side effects need to be taken into account when assessing the overall effectiveness. Components of the Effectiveness criteria are listed in Table 2.2. 
Table 2.2. Components of the Effectiveness criteria

\begin{tabular}{|c|c|}
\hline \multicolumn{2}{|c|}{ Effectiveness criteria } \\
\hline $\begin{array}{l}\text { Depth and } \\
\text { additionality }\end{array}$ & $\begin{array}{l}\text { Reduction in absolute or relative emission compared with a } \\
\text { business-as-usual (BAU) scenario. Additionality is a more specific } \\
\text { criterion that requires reductions to be additional to what would } \\
\text { occur in the absence of REDD (BAU). }\end{array}$ \\
\hline Breadth/scope & $\begin{array}{l}\text { Coverage of different sectors and type of forest users, type of } \\
\text { forest and type of mitigation measures included. }\end{array}$ \\
\hline $\begin{array}{l}\text { Flexibility and } \\
\text { robustness }\end{array}$ & $\begin{array}{l}\text { Ability to adapt to meet both diverse local conditions and } \\
\text { unknown future changes at all scales. Potential trade-offs } \\
\text { between flexibility and robustness need to be considered. }\end{array}$ \\
\hline Verifiability & $\begin{array}{l}\text { Verifiability depends on (i) the technology used to make accurate } \\
\text { and complete measurements; and (ii) the capacity to carry out } \\
\text { such measurements. }\end{array}$ \\
\hline $\begin{array}{l}\text { Displacement } \\
\text { of emissions } \\
\text { (leakage) }\end{array}$ & $\begin{array}{l}\text { Leakage can occur within or across countries, and also among } \\
\text { land use activities (e.g. between deforestation and degradation } \\
\text { activities if only one D is included). Generally, the larger the scale } \\
\text { and the broader the scope of REDD, the lower the risk of leakage. }\end{array}$ \\
\hline $\begin{array}{l}\text { Permanence and } \\
\text { liability }\end{array}$ & $\begin{array}{l}\text { Permanence relates to ensuring long-term reductions, i.e. } \\
\text { avoiding emissions reductions that are simply postponed for } \\
\text { a short period of time. Liability measures can take effect if } \\
\text { permanence has not been maintained. }\end{array}$ \\
\hline $\begin{array}{l}\text { Effect on other } \\
\text { mitigation } \\
\text { measures }\end{array}$ & $\begin{array}{l}\text { A real risk is that REDD efforts will come at the expense of other } \\
\text { climate mitigation measures. Such 'crowding out' effects are hard } \\
\text { to measure. }\end{array}$ \\
\hline
\end{tabular}

\subsubsection{Efficiency}

Efficiency refers to whether the given emission reduction is achieved at a minimum cost. Various costs must be considered when developing a REDD scheme. Costs can be categorised into start-up costs (or 'upfront capacity building costs', see Eliasch 2008) and ongoing emission reduction costs. The latter can be further sub-divided into running costs (or forest protection costs, see Eliasch 2008) and opportunity costs (see Chapter 5). In addition to the landowners' opportunity costs, their transaction costs for participating in the scheme must be taken into account - a sometimes neglected aspect with profound implications. Table 2.3 summarises the efficiency criteria. 
Table 2.3. Efficiency criteria

\begin{tabular}{|c|c|}
\hline $\begin{array}{l}\text { Start-up (upfront } \\
\text { capacity-building) costs }\end{array}$ & $\begin{array}{l}\text { Costs of setting up a REDD scheme, including } \\
\text { establishing technical infrastructure and governance } \\
\text { structures, and, most importantly, training and capacit) } \\
\text { building. }\end{array}$ \\
\hline
\end{tabular}

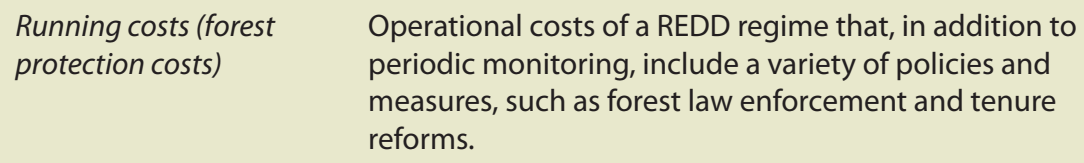

Landowners'

opportunity costs

Opportunity costs are the foregone economic benefits from the best alternative (non-forest) land uses, e.g., the minimum amount a landowner must be paid to be willing to stop deforestation and forest degradation/ DD (compensation payment). This will be a key cost component of a national PES system.

Landowners' transaction costs

To participate in the REDD scheme, the landowner is likely to incur additional costs (e.g. put up fences, get certified), which need to be factored into the compensation payments.

\subsubsection{Equity and co-benefits}

Most REDD proposals include non-climate objectives related to the distribution of benefits and costs, livelihoods/poverty reduction, protection of rights, and/or biodiversity (Chapter 11). The equity considerations have several dimensions, including fair distribution of benefits between and within countries and the effects of REDD activities on local and indigenous communities. Criteria for assessing co-benefits include economic development and poverty reduction, biodiversity, rights and forest governance (Table 2.4).

Table 2.4. Equity and co-benefits criteria

\section{Equity criteria}

Fair distribution among countries
One dimension relates to the poverty profile, i.e. (i) poor countries' abilities to participate in a REDD scheme (e.g. monitoring, reporting and verifying - MRV) and governance requirements); and (ii) preferential treatment of the poorest countries (e.g. in setting reference levels).

Another dimension of fairness relates to'not penalising early action' and 'not rewarding bad policies'. And, if basing reference levels on past deforestation, one should not penalise 'lack of development'. 
Table 2.4. (continued)

\begin{tabular}{ll}
\hline Equity criteria (continued) \\
\hline $\begin{array}{l}\text { Fair distribution } \\
\text { within countries }\end{array}$ & $\begin{array}{l}\text { This refers to intra-national fairness, i.e. the distribution } \\
\text { of costs and benefits across administrative levels (local vs. } \\
\text { national government) and across land use actors. }\end{array}$ \\
$\begin{array}{l}\text { Effects on local } \\
\text { and indigenous } \\
\text { communities }\end{array}$ & $\begin{array}{l}\text { The Bali Action Plan acknowledges the role of local and } \\
\text { indigenous communities in REDD activities. The practical } \\
\text { implications are that traditional rights will be recognised } \\
\text { and that indigenous communities will be included in the }\end{array}$ \\
\hline REDD decision-making process. \\
\hline $\begin{array}{l}\text { Economic } \\
\text { development and } \\
\text { poverty reduction }\end{array}$ & $\begin{array}{l}\text { REDD may enable or constrain economic development } \\
\text { at the national and subnational levels, and affect those } \\
\text { economically dependent on forests as well as national } \\
\text { economies as a whole. }\end{array}$ \\
\hline $\begin{array}{l}\text { Biodiversity } \\
\text { Carbon and biodiversity aims are largely compatible, but } \\
\text { there could be trade-offs, for example, in the geographical } \\
\text { targeting of funds (biodiversity and carbon hotspots may } \\
\text { not overlap). }\end{array}$ \\
\hline $\begin{array}{l}\text { REDD has the potential to improve forest governance and } \\
\text { governance }\end{array}$ & $\begin{array}{l}\text { rights, e.g. through more transparent forest information } \\
\text { systems. But, it also entails risks such as when the potentially } \\
\text { large sums of money generated by REDD triggers } \\
\text { corruption, mismanagement and elite capture. }\end{array}$ \\
\hline
\end{tabular}

\subsection{Concluding remarks}

Moving ahead with REDD and developing the global REDD architecture will require important decisions on the design. There is an urgent need for the UNFCCC to provide direction on some of the key issues. To make an informed choice, the trade-offs and implications of the various options must be carefully assessed. In essence, for REDD to become an internationally accepted mitigation mechanism, it will have to comply with at least three criteria. It will need to secure (i) actual emission reductions (be effective) at (ii) minimum cost (be efficient), while (iii) reducing undesired social and ecological tradeoffs (be equitable and provide co-benefits). 



\subsection{What will REDD cost?}

\subsubsection{Types of REDD costs}

Estimated costs of REDD vary with the data and modelling approach used and the types of costs considered. Studies report costs in terms of supplying or buying REDD, or both. Most estimates focus on the 'opportunity costs' of avoiding deforestation from a landowner's perspective (i.e. foregone economic benefits from alternative land uses), without the costs of developing institutional capacities and actually implementing and transacting a REDD programme.

Some economic models have estimated 'supply curves' ('marginal cost curves') that indicate a cost spectrum for incremental reductions in forest emissions (Figure 3.1). The cost curves slope upwards, showing that for small emissions reductions, costs can be kept low by, for example, protecting just the lowestcost lands; with greater reductions, the added incremental or 'marginal' costs rise as protection must extend to higher-cost lands and protection activities.. For example, estimates of total opportunity costs more than double in moving from $94 \%$ to $100 \%$ protection of the Brazilian Amazon forest, because of the high agriculture potential of just 6\% of the lands (Nepstad et al. 2007).

The costs of implementing REDD policies comprise upfront costs of 'capacity building'; ongoing 'administrative costs' of monitoring, enforcement and other activities needed to run a REDD programme; and 'transaction costs' involved in successfully connecting buyers and sellers. Countries will differ in their ability to reduce tropical forest emissions, and implementation costs will vary with national capacities and strategies. One-time needs for capacity building and policy reform for REDD in 40 countries were recently totalled at USD 4 billion (Eliasch 2008). In addition, the costs of generating valid REDD credits will crucially depend on the baseline-setting rules for how REDD efforts shall be compensated (see Chapter 6).

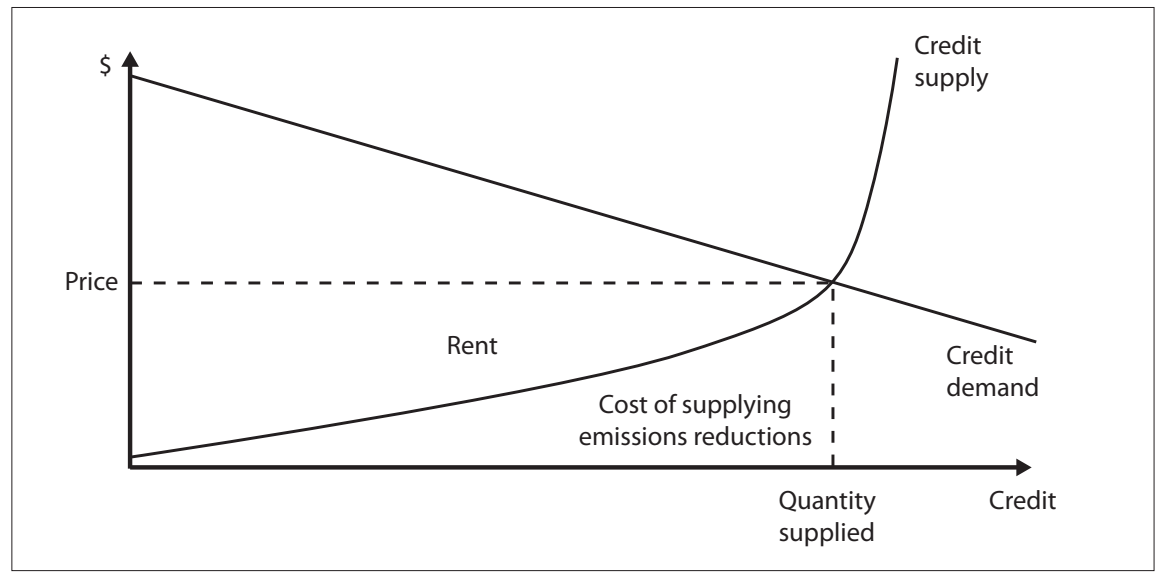

Figure 3.1. Supply and demand for REDD 'credits' 


\subsubsection{Modelling approaches}

Most estimates of REDD costs come from 'bottom-up' or 'engineering' studies based on detailed information on particular activities in particular locations, at fixed prices. In contrast, 'top-down' models are more aggregate and take into account commodity market interactions - both demand and supply. Topdown models have generally yielded higher estimates for the costs of largescale REDD, partly because they account for market feedbacks (see Table 3.1). Feedbacks occur as reductions in deforestation lower timber harvests and land conversion to agriculture. Consequent lower growth in supply of soybeans, cattle, and timber will raise their prices, thereby raising the incentives to deforest, as long as the unsatisfied demand does not abate completely. Such feedbacks will raise the costs of REDD and increase the risk of 'leakage', by providing incentives to shift deforestation elsewhere.

Table 3.1. Halving global deforestation: comparison between bottom-up and top-down models

\begin{tabular}{|c|c|c|}
\hline & $\begin{array}{l}\text { Bottom-up } \\
\text { Analysis of eight tropical } \\
\text { countries (Grieg-Gran in Eliasch } \\
\text { 2008) }\end{array}$ & $\begin{array}{l}\text { Top-down } \\
\text { Review of three global land use } \\
\text { models (Kindermann et al. 2008) }\end{array}$ \\
\hline $\begin{array}{l}\text { Cost of } \\
\text { halving } \\
\text { deforestation }\end{array}$ & USD 7 billion/year & USD 17.2-28 billion/year \\
\hline Time frame & $\begin{array}{l}\text { Immediate; and annual } \\
\text { reductions assured over } 30 \text { years }\end{array}$ & By 2050 \\
\hline $\begin{array}{l}\text { Costs } \\
\text { included }\end{array}$ & $\begin{array}{l}\text { Opportunity costs of protecting } \\
\text { forests (e.g. the costs of } \\
\text { supplying emissions reductions } \\
\text { in Figure } 3.1 \text { ); estimated } \\
\text { administration costs of USD } \\
233-500 \text { million/year for REDD; } \\
\text { and estimated USD } 50 \text { million } \\
\text { one-time cost for national forest } \\
\text { inventories in } 25 \text { countries } \\
\text { plus USD 7-17 million/year to } \\
\text { administer them }\end{array}$ & $\begin{array}{l}\text { Opportunity cost curves are } \\
\text { estimated. Total costs above } \\
\text { include opportunity costs of } \\
\text { supplying emissions reductions } \\
\text { plus the 'rents' (profits) earned } \\
\text { by REDD providers in selling } \\
\text { reductions at a single market } \\
\text { price (Figure 3.1). This is the } \\
\text { expenditure for a buyer in a } \\
\text { competitive market; the seller's } \\
\text { 'rents' are a redistribution of } \\
\text { resources, not a cost to society as } \\
\text { a whole. However, the rents affect } \\
\text { the cost effectiveness or ability of } \\
\text { a REDD programme to maximise } \\
\text { reductions for a limited budget. }\end{array}$ \\
\hline Comments & Commodity prices fixed & $\begin{array}{l}\text { Market effects incorporated (e.g. } \\
\text { price rises as supply falls), which } \\
\text { tends to raise costs }\end{array}$ \\
\hline
\end{tabular}


Differences in the modelled 'baseline' scenario of what deforestation would be without REDD policies also affect the estimated costs of REDD. Greater forecasted deforestation under the 'business as usual' (BAU) scenario would bring higher emissions to be potentially reduced, but may also mean greater modelled pressures on forests and thus higher costs of forest protection. Other differences in data and assumptions contribute to varying estimates of REDD costs (Table 3.2).

Table 3.2. Effects of including different modelling features on the estimated costs of REDD

\begin{tabular}{|c|c|}
\hline Select features included in the model & Effect on costs \\
\hline $\begin{array}{l}\text { Price feedbacks: lower supplies of timber, crops, etc. raise prices } \\
\text { and thus opportunity costs of forest protection. }\end{array}$ & + \\
\hline $\begin{array}{l}\text { Number of deforestation drivers modelled: accounting for more } \\
\text { drivers, such as timber and agriculture, will raise opportunity } \\
\text { costs of forest protection. Accounting for new future drivers, such } \\
\text { as biofuels, rather than extrapolating from past drivers, can also } \\
\text { increase estimated costs. }\end{array}$ & + \\
\hline Implementation and transaction costs, investment risks. & + \\
\hline $\begin{array}{l}\text { Land conversion benefits as opposed to costs: one-time benefits } \\
\text { from timber harvests upon forest clearance will raise costs of forest } \\
\text { protection. }\end{array}$ & + \\
\hline $\begin{array}{l}\text { Greater assumed parameter for the 'elasticity of transformation', } \\
\text { the convertibility of forest land to other uses, raises costs in some } \\
\text { models. }\end{array}$ & + \\
\hline $\begin{array}{l}\text { Carbon density/releases: greater emissions avoided per hectare } \\
\text { protected will lower cost per ton. }\end{array}$ & - \\
\hline $\begin{array}{l}\text { Timber benefits from protected forests (e.g. sustainable forest } \\
\text { management). }\end{array}$ & - \\
\hline $\begin{array}{l}\text { Scope of the REDD model (forestry activities, sectors, countries, } \\
\text { gases): greater scope implies less leakage and more opportunity } \\
\text { for low-cost global reductions. }\end{array}$ & - \\
\hline $\begin{array}{l}\text { Scope of incentives: more complete coverage lowers leakage and } \\
\text { thus costs. }\end{array}$ & - \\
\hline $\begin{array}{l}\text { Targeting of incentives: targeting payments at emissions } \\
\text { reductions lowers transfers to non-emitters and thus costs (to } \\
\text { buyers), but avoiding 'leakage' and ensuring equity must also be } \\
\text { considered. }\end{array}$ & - \\
\hline
\end{tabular}




\subsection{How will REDD affect the overall strategy for reducing emissions?}

Consideration of deforestation and other land-based options for reducing emissions within climate models is a relatively new field. Nevertheless, results from the Energy Modeling Forum 21 (Rose et al. 2007) and related efforts suggest that reducing deforestation, in addition to planting trees (afforestation and reforestation, A/R), changes in forest management, and other land-based options to mitigate GHGs, may provide important cost savings to reach climate stabilisation goals over the next century (Table 3.3, Fischer et al. 2007).

These cost savings may enable greater global emissions reductions than could be achieved without REDD for the same overall cost. Estimated savings of USD 2 trillion through global forestry mitigation could finance a 10\% stricter target or $0.25^{\circ} \mathrm{C}$ less of warming over the century depending on the modelled scenario (see Table 3.3). The potential gains from REDD depend on the target GHG concentrations in the atmosphere and the menu of available options for reducing emissions. More alternatives bring more potential sources of cheap reductions and reduce the reliance on any single option for meeting a particular emissions target at least cost. Another critical assumption affecting the estimated role of REDD across models is the expected development of future biofuel technologies (Table 3.3). In particular, biomass production for electricity generation combined with carbon capture and sequestration could, in theory, be a powerful competitor for land if it became a feasible means to generate energy with negative carbon emissions (e.g. Obersteiner et al. 2001).

Most studies of REDD focus on the economic potential, assuming that institutional frameworks and capacities are readily available to immediately implement REDD worldwide. However, not all countries will choose to join an international climate agreement or be able to effectively reduce deforestation emissions in the near term. These institutional and political barriers lower the realistic scale of reductions and their effective global impact. Inconsistent incentives for REDD and other GHG reductions across countries would create the potential for international emissions 'leakage' or 'displacement', with reductions in one country potentially being offset by increases elsewhere. For example, Gan and McCarl (2007) estimate international leakage as high as $42-95 \%$ in the forestry products industry. 
Table 3.3. Estimated potential of REDD to lower costs and buy additional emissions reductions: comparison of models

\begin{tabular}{|c|c|}
\hline Model and type & Results \\
\hline $\begin{array}{l}\text { WITCH coupled with } \\
\text { GTM (integrated } \\
\text { assessment analysis; } \\
\text { Tavoni et al. 2007) }\end{array}$ & $\begin{array}{l}\text { Including emissions reductions from deforestation, } \mathrm{A} / \mathrm{R} \text { and } \\
\text { changes in forest management enables an atmospheric } \\
\text { target of } 550 \mathrm{CO}_{2} \text { e parts per million by volume (ppmv) for } \\
\text { the same total cost as a } 600 \text { ppmv target without forestry } \\
\text { mitigation. Global forestry mitigation saves about USD } 2 \\
\text { trillion; this buys the climate an estimated additional } 0.25^{\circ} \mathrm{C} \\
\text { less warming by the end of the century at no added cost } \\
\text { (compared with energy sector only reductions). }\end{array}$ \\
\hline $\begin{array}{l}\text { GLOCAF coupled } \\
\text { with GCOMAP } \\
\text { and IIASA cluster } \\
\text { model (integrated } \\
\text { assessment analysis; } \\
\text { Eliasch 2008) }\end{array}$ & $\begin{array}{l}\text { The costs of reducing global emissions to } 50 \% \text { of } 1990 \text { levels } \\
\text { by } 2050 \text { ( } 475 \mathrm{CO}_{2} \text { e stabilisation) may be lowered by } 25-50 \% \\
\text { in } 2030 \text { and } 20-40 \% \text { in } 2050 \text { when deforestation reductions } \\
\text { and A/R are included. The cost savings of almost USD } 2 \\
\text { trillion could finance a } 10 \% \text { lower global emissions target. }\end{array}$ \\
\hline $\begin{array}{l}\text { MESSAGE } \\
\text { (integrated } \\
\text { assessment analysis; } \\
\text { e.g. Rao and Riahi } \\
\text { 2006; Riahi et al. } \\
\text { 2006) }\end{array}$ & $\begin{array}{l}\text { Includes a broad set of land-based options: avoided } \\
\text { deforestation, A/R, agricultural mitigation, and biofuels } \\
\text { for both liquid fuels and energy with carbon capture and } \\
\text { sequestration. The biofuel options compete heavily with } \\
\text { forests; forestry and biofuel options contribute } 1-2 \% \text { and } \\
6-24 \% \text {, respectively, over the next } 50 \text { years, and } 4-8 \% \text { and } \\
14-29 \% \text { over the next century when stabilising at about } 650 \\
\mathrm{CO}_{2} \text { e ppmv. Substantial conversion of primary forests to } \\
\text { managed plantation forests is predicted. }\end{array}$ \\
\hline $\begin{array}{l}\text { GRAPE (integrated } \\
\text { assessment analysis; } \\
\text { Kurosawa 2006) }\end{array}$ & $\begin{array}{l}\text { Includes avoided deforestation, } A / R \text {, agricultural mitigation, } \\
\text { and biofuels for liquid fuels (but not for energy). It estimates } \\
\text { a large role for forestry activities: } 55 \% \text { and } 15 \% \text { of the } \\
\text { abatement over the next } 50 \text { and } 100 \text { years, respectively. }\end{array}$ \\
\hline $\begin{array}{l}\text { GTEM ('general } \\
\text { equilibrium' model; } \\
\text { Jakeman and Fisher } \\
\text { 2006) }\end{array}$ & $\begin{array}{l}\text { Includes avoided deforestation, } \mathrm{A} / \mathrm{R} \text { and agricultural } \\
\text { mitigation; excludes biofuels. For } 650 \mathrm{CO}_{2} \text { e concentrations } \\
\text { target, estimated contribution of forestry is } 11 \% \text { of total } \\
\text { abatement over the next } 50 \text { years, with all land-based } \\
\text { mitigation options saving USD 1.6- } 7.6 \text { trillion depending on } \\
\text { the inclusion of non- } \mathrm{CO}_{2} \text { mitigation options. }\end{array}$ \\
\hline
\end{tabular}

\subsection{How will REDD affect the carbon price and efforts to reduce emissions in other sectors?}

The potential cost advantages of REDD may detract from abatement in other sectors, if REDD credits were made fully interchangeable with other GHG credits. A perceived risk is that REDD may 'flood' the carbon market, dampening the price signal to develop and deploy clean energy technologies. 
The effect of REDD on carbon prices and technology incentives depends on several factors:

- How much emissions from avoided deforestation can actually be achieved and credited in practice (the supply of REDD), which depends on the total costs of REDD, the countries that participate and the crediting conditions.

- The demand for REDD, based on the overall emissions reduction target and the availability and costs of other mitigation alternatives. Under stricter targets, there will be greater demand for REDD and more expensive reductions from other sectors.

- The options for applying ('banking') early actions to reduce emissions against future obligations, thus potentially raising current demand for REDD.

- Rules on the 'fungibility' of REDD credits. Restricting the use of REDD and other mitigation options would tend to raise the carbon price (and the total costs).

Tavoni et al. (2007) estimate that global implementation of REDD plus $\mathrm{A} / \mathrm{R}$ and changes in forest management would delay deployment of some technologies and reduce investment in energy research and development by about $10 \%$, for a fixed emissions reduction target. Anger and Sathaye (2006) find a $40 \%$ carbon price reduction from introducing REDD into a market that also allows unlimited credits for developing country mitigation through the clean development mechanism. Other studies find more muted impacts, depending on the policy scenario.

According to Eliasch (2008), introducing REDD credits along with modest quantitative limitations on REDD has a negligible estimated effect on the European Union's carbon price, even if countries can satisfy 50-85\% shares of their abatement through international credits, depending on the stringency of the European Union target. The precise proportional impact of REDD on the price depends on the assumptions determining the shape of the cost curves, including the costs of the potential alternatives.

Sufficiently ambitious and credible long-term targets anticipated by market participants also provide incentives for saving up credits for use under tighter future targets. Taking into account such 'banking,' Piris-Cabezas and Keohane (2008) estimate a global REDD programme would lower the global carbon price by $14 \%$, while using all forestry mitigation options would reduce the price by $31 \%$, for a fixed emissions reductions target. Doubling the estimated supply of REDD credits has a relatively small effect on the modelled price, as additional credits are 'banked' and used gradually over time. If REDD helps build a store of relatively low-cost emissions reductions, this 'bank' can also dampen price volatility by providing a buffer against unexpected price spikes in the future. 


\subsection{Conclusion}

The latest science suggests that only a global programme that begins almost immediately and achieves large reductions in GHGs by mid-century can preserve options to avoid dangerous interference with the climate system. Despite different assumptions, a range of economic models indicates that REDD can make a significant contribution to cost-effectively stabilising GHG concentrations at this scale and speed.

The cost and timing of REDD are critically important. Estimated cost savings from REDD could buy greater and faster global emissions cuts than can be achieved for the same global expenditure without REDD. Stabilising GHG concentrations at safe levels requires ambitious efforts to reduce emissions quickly from tropical forests as well as other sectors. Most estimates of REDD policy costs focus on 'opportunity costs' without considering capacity building and transaction costs, which may amount to significant additional requirements. However, the long-term estimated costs savings from global forestry in most models provide significant scope for covering these additional expenses.

The economic impact of REDD depends on the overall climate targets and policy architecture, the design and implementation of REDD and its fungibility with the rest of the GHG market. The potential risk of REDD supply 'flooding' the carbon market can be contained by policy designs ranging from strict and long-term targets with 'banking', to modest limits on the use of REDD and other types of credits.

Early emissions reductions also have particular value as a global insurance policy for maintaining climatic options in light of scientific uncertainty (Fisher et al. 2007). As tropical forests are disappearing, REDD is also a costeffective opportunity for reducing emissions that is available for a limited time only. The time-limited and irreversible nature of REDD - once deforestation occurs, it cannot be avoided in the future - adds further value to protecting tropical forests now rather than foreclosing future options for lowering global emissions. 
arrangements between national and subnational levels may haze the distinction between scales. The level of implementation is of secondary importance: implementation at the national level may include both nationally-implemented projects and a national REDD strategy that credits projects implemented by others. Similarly, a subnational project approach to implementation can be backed-up by good national policies that make achieving project objectives easier.

\subsection{Three options for the scale of REDD}

\subsubsection{Subnational approach}

Figure 4.1 illustrates the difference between the three options. The subnational approach proposes that REDD activities would be implemented in a defined geographical area, or as projects by individuals, communities, nongovernmental organisations (NGOs), private companies or national or local governments. As with all three approaches, crediting REDD activities would require internationally agreed rules for monitoring, reporting and verification (MRV), a system for crediting (payment), and institutional arrangements at both the national level (e.g. a designated national authority or similar entity that approves all projects) and the international level (e.g. a supervisory body and a centralised project and credit registry).

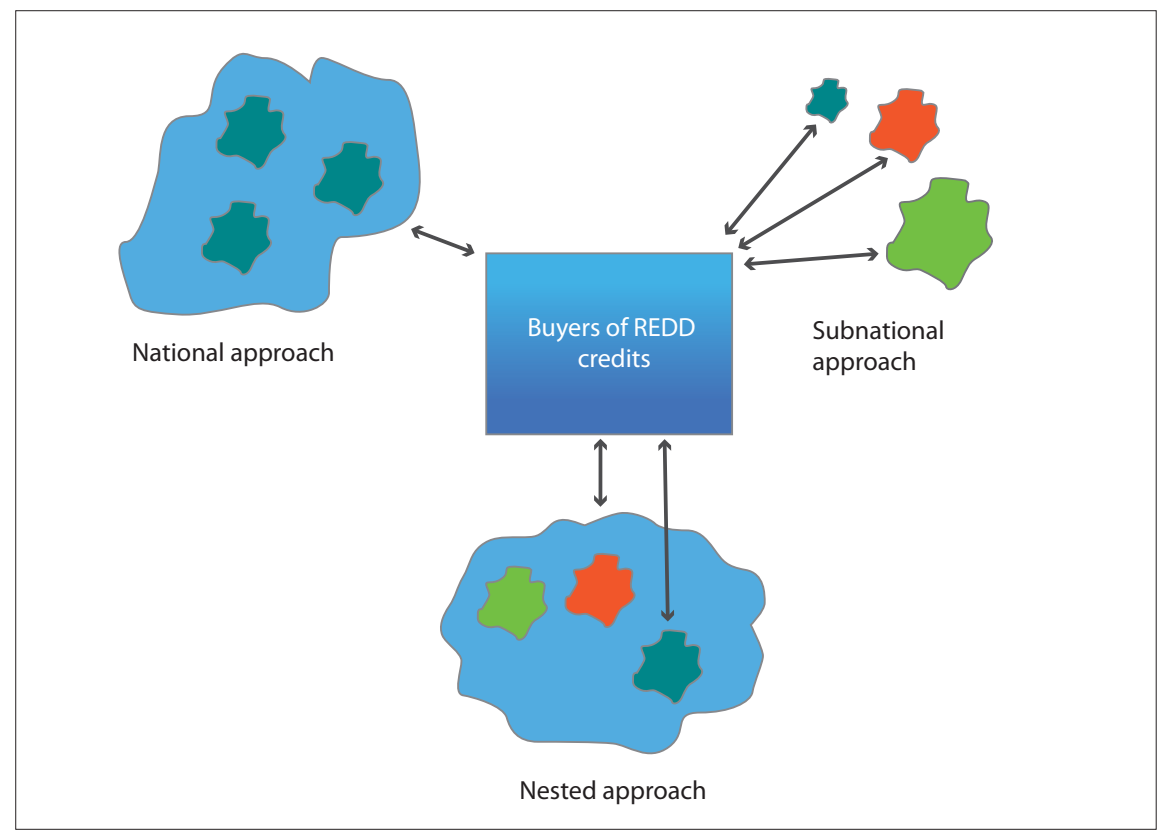

Figure 4.1. The three approaches to REDD accounting and and crediting Note: Arrows indicate money from the international buyers and information from the (sub)national entities. 
The modalities and procedures developed for the Clean Development Mechanism (CDM) under the Kyoto Protocol could serve as a model for the institutional set-up. The CDM allows developed (Annex I) countries to offset their greenhouse gas emissions by supporting projects in developing countries that reduce emissions. In the forestry sector, only afforestation and reforestation (A/R) projects are currently eligible and, so far, only one project has been approved. The CDM has proved more successful in other sectors, particularly in energy. CDM had a primary market value of USD 7.4 billion in 2007 (Hamilton et al. 2008). Progress of A/R CDM projects is slow because the complex rules, methodologies and registration costs make transaction costs very high. Other obstacles are the lack of transferability of the temporary credits assigned to projects and the exclusion of temporary credits from the EU Emission Trading System (ETS). The ETS is by far the largest carbon market, with a volume of USD50 billion in 2007 , or $78 \%$ of the global carbon trade (Hamilton et al. 2008).

Another example of a subnational approach is the voluntary carbon market in projects for preventing deforestation. The transactions in the voluntary carbon market reached USD330 million in 2007 (forestry-related projects comprising $18 \%$ of market share), which was less than $5 \%$ of the CDM primary market. Eighty per cent of the transactions in the voluntary carbon market involved private sector buyers (Hamilton et al. 2008).

Given the relative success of CDM in other sectors, its established institutional structure and the difficulties some countries may have in taking a national approach to REDD, some Parties to the UNFCCC argue that a project-based mechanism should be included in the global REDD framework, e.g. the recent submission to UNFCCC by Paraguay on behalf of Argentina, Panama, Peru, Paraguay and Peru (see Appendix). The post-2012 negotiations under the Kyoto Protocol (Article 3.9) also include discussions on REDD in CDM. However, the negotiations should recognise that the limited success of $A / R$ projects suggests that a project-based REDD approach cannot simply replicate the CDM model.

\subsubsection{National approach}

Most country submissions to UNFCCC advocate a national approach. This reflects their previous experiences with leakage and transaction costs in project approaches. The national approach also addresses sovereignty issues. It acknowledges that combating deforestation entails broad policy changes and thus has the potential to achieve larger-scale and more permanent reductions than subnational or nested approaches. 
Governments taking a national approach would establish a national system for MRV and would be rewarded for emission reductions measured from an established reference level (discussed in Chapter 6). Reductions would be rewarded by allocation of tradable carbon credits, financial transfers from a global fund or other mechanisms. In the national approach, no direct credits would be issued internationally for activities that reduce emissions at the subnational level.

In order to access international incentives, each participating country, depending on its circumstances, would be responsible for implementing policies and measures to reduce emissions from deforestation and forest degradation over its entire territory. Policies and measures might include a system to provide credits (payment for environmental services, or PES) to local communities. A major advantage of the national approach is that governments can put in place a broad set of policies and actions to reduce deforestation and forest degradation.

\subsubsection{Nested approach}

Given the diverse national circumstances, a number of UNFCCC submissions suggest integrating subnational activities into a national accounting framework through a 'nested' approach (first presented coherently by Pedroni et al. 2007). Taking this approach, countries could start REDD activities at any level. Those that decide to start at the subnational level could scale up to a national approach as they strengthen their capacity and improve governance. Transition to a national approach would be mandatory, either within an agreed time frame or when an agreed percentage of forest area is covered by REDD projects, whichever comes first.

Although the transition to a national approach would be obligatory, it would still be possible to credit individual project activities. The nested approach therefore has two unique features: Firstly, the capacity to scale up from a subnational to a national approach over time. Secondly, countries have the option to account for and receive international credits at subnational and national levels simultaneously (see Figure 4.1). Also, different countries could use different crediting mechanisms at the same time.

In a nested approach, where accounting and crediting takes place at both subnational and national levels, procedures for MRV and setting reference levels would need to be harmonised. An arrangement for sharing credits between the two levels could be modelled on the Kyoto Protocol Joint Implementation (JI) mechanism. At the end of each accounting period, the country would have to deduct all credits issued and committed at subnational level from national credits for country-wide emission reductions (see Box 4.1). 
Should the national level fail to deliver carbon benefits, independently validated and verified subnational activities would still be credited.

\section{Box 4.1. How a nested approach might work}

A project generates 1000 tonnes of carbon dioxide emission reductions during the accounting period. The country's overall reduction (carbon credits) is 5000 tonnes during the period. The 1000 tonnes already credited to the project have to be deducted from the national balance. To allow for project-level leakage, monitoring, reporting and verification (MRV) costs, and the risk of non-permanence (higher emissions in the future), the government may retain a certain share of the carbon credits assigned to the project. Thus, the government and the project might make a deal that the project keeps $70 \%$ of the credits while the government keeps $30 \%$. In this scenario, the project would keep 700 credits and the government 4300 credits.

Even under an exclusively national approach, a country could also allocate some of the national credits to projects. This would reduce deforestation and degradation, and compensate districts, communities and farmers for the cost of forest conservation. In other words, a country could establish a national system for Payments for Environmental Services (PES) that extends the global REDD system to the local level. In a nested approach this would be considered part of the international agreement, whereas it would not be in an exclusively national model.

\subsection{Assessment of the three approaches}

The merits of the three approaches can be assessed in relation to the ' $3 \mathrm{E}$ ' framework, elaborated in Chapter 2: Is the mechanism achieving its greenhouse gas emission targets (carbon effectiveness)? Are these targets achieved at the minimum cost (cost efficiency)? What are the distributional implications and co-benefits (equity and co-benefits)? This section assesses each criterion, and is summarized in Table 4.1.

\subsubsection{Effectiveness}

In terms of carbon effectiveness and emission reduction goals, the differences between the three approaches can be assessed in three main dimensions: (i) ability to deal with leakage and additionality; (ii) overall level of participation, which will influence overall emissions reductions achieved; and (iii) broad policy reforms, which will influence the depth, cost and permanence of reductions. 
Table 4.1. Pros and cons of subnational, national and nested approaches

\begin{tabular}{|c|c|c|c|}
\hline \multirow[b]{2}{*}{ REDD model } & \multicolumn{3}{|c|}{ Criteria } \\
\hline & Effectiveness & Efficiency & $\begin{array}{l}\text { Equity and co- } \\
\text { benefits }\end{array}$ \\
\hline $\begin{array}{l}\text { Subnational } \\
\text { approach }\end{array}$ & $\begin{array}{l}\text { + Broad short-term } \\
\text { participation } \\
+ \text { Attractive to private } \\
\text { funders } \\
\text { - Domestic leakage a } \\
\text { problem } \\
\text { - Does not trigger } \\
\text { the required policy } \\
\text { changes } \\
\text { - Weak involvement of } \\
\text { host countries }\end{array}$ & $\begin{array}{l} \pm \text { MRV costs lower } \\
\text { overall but higher } \\
\text { per } \mathrm{CO}_{2} \text { equivalent } \\
+ \text { Differentiated } \\
\text { incentive payment } \\
\text { possible: lowers } \\
\text { costs }\end{array}$ & $\begin{array}{l}\text { + Easier participation } \\
\text { by poor countries } \\
\text { and those with } \\
\text { weak governance } \\
\text { + Can target poor } \\
\text { domestic groups } \\
\text { and create more } \\
\text { opportunities } \\
\text { for community } \\
\text { participation }\end{array}$ \\
\hline $\begin{array}{l}\text { National } \\
\text { approach }\end{array}$ & $\begin{array}{l}\text { + Broader set of } \\
\text { policies pursued } \\
+ \text { Captures domestic } \\
\text { leakage } \\
+ \text { Stronger host } \\
\text { country ownership } \\
\text { - Unsolved issues } \\
\text { of reference levels } \\
\text { (additionality) }\end{array}$ & $\begin{array}{l}\text { + Lower MRV and } \\
\text { transaction costs } \\
\text { per } \mathrm{CO}_{2} \text { equivalent } \\
+ \text { Low-cost (non- } \\
\text { PES) policies } \\
\text { available } \\
\text { - Potential for policy } \\
\text { and governance } \\
\text { failure }\end{array}$ & $\begin{array}{l}\text { + Potentially larger } \\
\text { overall transfers } \\
+ \text { Better alignment } \\
\text { with national } \\
\text { development } \\
\text { strategies } \\
\text { - Favours middle- } \\
\text { income countries } \\
\text { - Risk of high level } \\
\text { and elite capture } \\
\text { ('nationalisation' of } \\
\text { carbon rights) }\end{array}$ \\
\hline $\begin{array}{l}\text { Nested } \\
\text { approach }\end{array}$ & $\begin{array}{l}\text { + Combines strengths } \\
\text { of other two } \\
\text { approaches } \\
+ \text { Flexibility based } \\
\text { on national } \\
\text { circumstances } \\
+ \text { Potential for larger } \\
\text { overall transfers } \\
\text { - Unsolved issues } \\
\text { of reference levels } \\
\text { (additionality) }\end{array}$ & $\begin{array}{l}\text { + Differentiated } \\
\text { compensation } \\
\text { pay and low-cost } \\
\text { broad policies } \\
\text { - High MRV } \\
\text { costs (requires } \\
\text { disaggregated } \\
\text { national data) } \\
\text { - Challenges in } \\
\text { harmonising } \\
\text { national and } \\
\text { subnational }\end{array}$ & $\begin{array}{l}\text { + Increased country } \\
\text { participation and } \\
\text { larger transfers to } \\
\text { poor countries } \\
+ \text { Possible to target } \\
\text { poor groups }\end{array}$ \\
\hline
\end{tabular}

National approaches must set credible national reference levels (credit baselines) and address questions of permanence and liability (discussed in Chapter 8). International negotiations have not yet resolved all the issues associated with doing this. There is a real risk that, because so many criteria for setting baselines are being discussed (e.g. national circumstances), baselines may be 
inflated, which will generate 'tropical hot air' (no additionality) (see Chapter 6). This would undermine the effectiveness and also the long-term credibility of national systems.

The geographical scope of national and nested approaches is potentially much larger than the scope of subnational approaches, thus addressing the problems of domestic leakage in accounting and thereby achieving greater effectiveness (M-Co Consulting, 2008; see also Chapter 7).

Currently, most developing countries cannot take a national approach because their MRV infrastructure is inadequate. This raises the problem of international leakage. The flexibility of the nested approach should permit most countries to participate sooner, either taking a (temporary) project approach or a national approach, or by pursuing both simultaneously. The choice will depend on their capacity for MRV, whether or not they have institutions in place to handle REDD funds and the nature of their national REDD strategy. The flexibility of the nested approach and the scope for broad participation should result in lower emissions compared to the other approaches.

Private investors may be reluctant to buy emission reductions from countries. They may prefer to invest in 'tangible' forest projects, which are directly associated with emissions reductions and other benefits, such as conserving biodiversity and reducing poverty. Because they have limited or no control over host country risks private investors are also less likely to invest upfront in emission reductions at the national level than directly in forest projects. This could exacerbate the problems of limited country participation.

Reforms such as changes to land tenure and improving governance could be key elements of a national REDD strategy. However, it would be difficult to trace the effects of such reforms to particular geographical areas. Also, these kinds of reforms would generally not fall within the scope of a subnational or project-based approach. Thus, national approaches are likely to encourage broader and more strategic policies compared to subnational approaches, and lead to deeper and longer-term emissions cuts.

\subsubsection{Efficiency}

The cost efficiency of the three approaches to REDD is likely to be affected by: (i) the costs of monitoring, reporting and verification (MRV); (ii) the costs of implementing policies; and (iii) opportunity cost payments.

A national MRV infrastructure has significant economies of scale. This means that the national approach is likely to be more efficient than nested and subnational approaches in terms of cost per unit of carbon dioxide emission 
reduction or area covered. For example, an exclusively national approach would not necessarily require disaggregating data to regional or district levels, reducing the number of sample plots that need to be monitored. The nested approach costs more than the national approach because monitoring and accounting must be at both national and subnational levels (disaggregating national level data is costly).

A second element affecting efficiency is the cost of implementing REDD policy. Implementing a system to credit subnational units (a national PES system) incurs costs such as the cost of registering projects with central institutions, the costs of validation and verification, and the costs of administering contracts. Economies of scale favour nationwide implementation. However, while a national system may have the potential to generate greater emissions reductions at lower cost, bureaucracy and corruption could make a national system inefficient. A subnational approach may have higher overall transaction costs per unit of emission reduction, but may be run more efficiently. Subnational approaches would typically take the form of small projects managed by private entities that have experience in carbon market mechanisms and that prioritise cost efficiency.

National approaches may include broad policy reforms. Many of these will be cheaper to implement than payment for environmental services (PES) schemes. In some cases reforms might even generate savings, such as by removing subsidies that stimulate deforestation and degradation.

The opportunity costs of forest conservation (typically the profits from agriculture and timber harvesting that could be generated from the land) vary greatly among those who hold rights to use forests. If rights holders could be compensated according to the specific opportunity costs they incur, overall costs would be substantially lower. In a study from Brazil, Börner and Wunder (2008) estimate that perfectly differentiated payments save $45-75 \%$ compared to uniform compensation.

Introducing differentiated payments might be more realistic in a subnational approach than in a national system where the transaction costs of doing so would be higher. However, introducing differentiated payments does raise equity issues as some of the poorest rights holders also have the lowest opportunity costs. The difficulties experienced in excluding non-additional activities (leading to inefficient payments) can be seen in the national PES system in Costa Rica (Karousakis 2007). 


\subsubsection{Equity}

Equity is an issue that needs to be addressed between countries (international) and within countries (intra-national). The latter is to a large extent determined by national REDD strategies and policies. Although an international REDD agreement is likely to be 'implementation neutral', in the sense that it will not specify which national policies are to be implemented, the global REDD regime will have implications for domestic distribution of benefits and costs.

At the international level, a regime allowing only national approaches to REDD could exclude most of the low-income countries on grounds that they have inadequate infrastructure for MRV and poor governance. Thus, the international flow of money could be skewed towards a few middle-income countries, such as Brazil. However, subnational approaches might not necessarily be better in this regard, as illustrated by the CDM experience. In 2007, 73\% of all CDM credits sold were 'made in China' (Hamilton et al. 2008). This points to the need - irrespective of the approach chosen - to strengthen national capacity and institutions and, more generally, to improve governance and accountability to ensure participation of the poorest countries.

In terms of intra-national equity, a centralised national approach could limit the participation of rural communities in the design and implementation of REDD. This could result in inequitable sharing of benefits and the 'nationalisation' of carbon rights. Large new financial flows may increase the risk of corruption and be captured by the state, preventing the benefits from reaching the poor. Governments also have decidedly mixed track records in promoting inclusive decision-making processes (Foti et al. 2008) and may have little incentive to ensure broad local participation in REDD. If processes in national approaches are inequitable, they may result in inequitable outcomes. On the other hand, a national approach may align with national development strategies and bring long-term development benefits.

Smaller scale subnational and nested approaches may be more flexible than larger scale national approaches in responding to needs in specific contexts. Evidence from some carbon-credit forestry projects suggests that they can strengthen local capacities, participatory decision making and communitybased resource management (Corbera 2005). However, private investors and conservation NGOs have a mixed track record when it comes to factoring community concerns into their projects. Carbon markets are driven primarily by global climate protection objectives, rather than local socio-economic objectives. Both subnational and national approaches are likely to face challenges in this area, but the drivers shaping the level of participation, along with the actors and processes involved, will be different. 


\subsection{Summary and concluding remarks}

Three approaches to the geographical level or scale of REDD accounting and incentive mechanisms are under discussion: direct support to projects (subnational level), direct support to countries (national level), or a hybrid ('nested') approach combining the two.

A subnational or project approach allows for early involvement and wide participation, and is attractive to private investors. However, this approach may suffer from leakage (increased emissions outside project boundaries) and cannot address the broader forces driving deforestation and forest degradation.

A national approach allows pursuit of a broad set of policies, addresses domestic leakage and creates country ownership. In the short to medium term, however, this approach is not feasible for many countries. It is also susceptible to governance failures, and may be less likely to mobilise private investment or involve local government.

A nested approach is the most flexible. It allows countries to start subnational activities and gradually move to a national approach. The nested approach allows both approaches to coexist in a system where REDD credits are generated by both projects and government, thus maximising the potential of both subnational and national approaches. However, a challenge in a nested approach is to harmonise the two levels. 


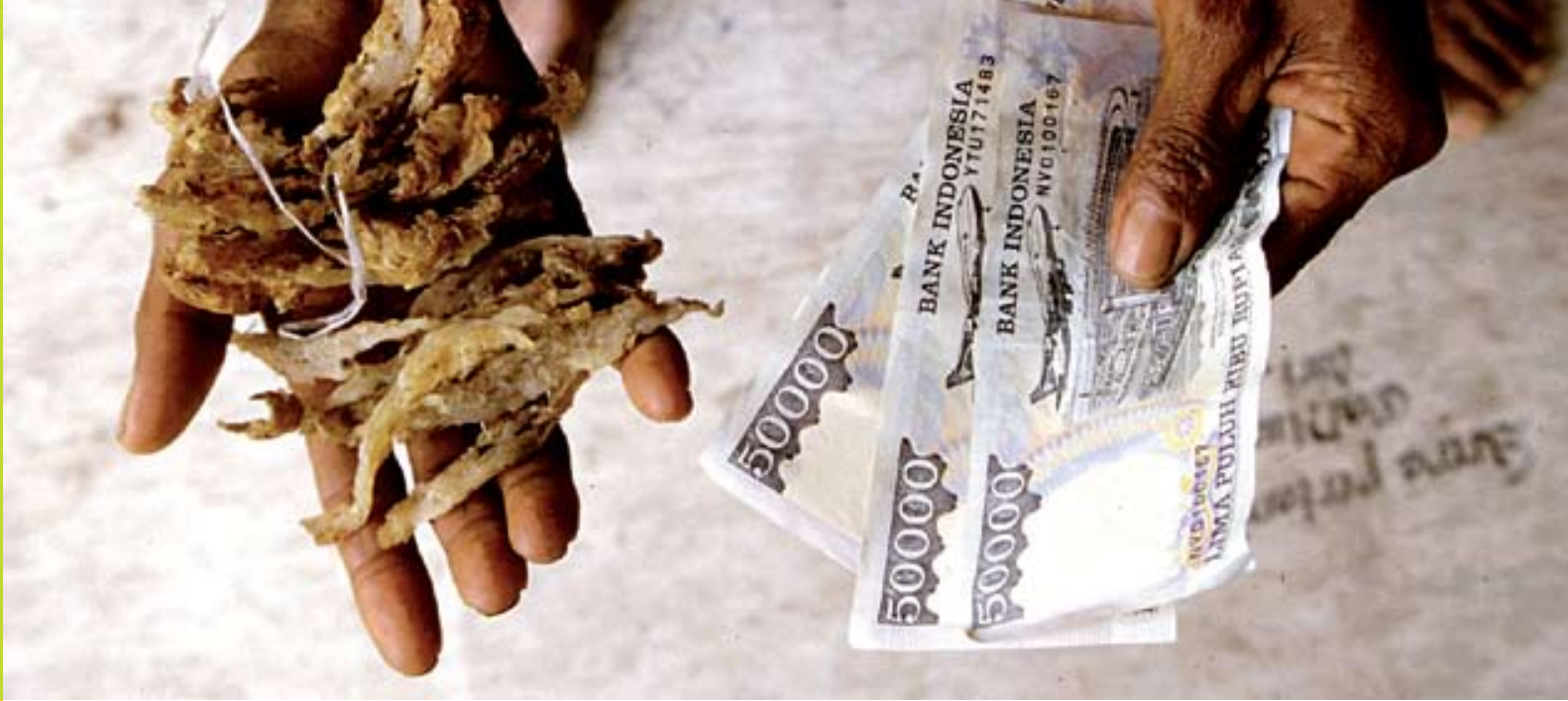

\section{Chapter 5}

\section{How do we match country needs with financing sources?}

Michael Dutschke and Sheila Wertz-Kanounnikoff

With Leo Peskett, Cecilia Luttrell, Charlotte Streck and Jessica Brown

\subsection{The challenge: Effective mechanisms to respond to diverse circumstances}

Reducing emissions from deforestation and forest degradation (REDD) is potentially a low-cost option for mitigating climate change, if acted upon today (Stern 2006). If forest carbon credits are included in global emissions trading, the estimated cost of halving net global carbon dioxide emissions from forests by 2030 is USD 17-33 billion annually (Eliasch 2008). The Thirteenth Conference of the Parties (COP 13) to the United Nations Framework Convention on Climate Change (UNFCCC) in 2007 laid the foundations for including REDD in developing countries in the post-2012 climate protection regime. Developed countries are encouraged to help find ways of financing these REDD activities in developing countries.

Developing countries differ in their capacity to reduce forest emissions. This is due to differing national circumstances as regards the drivers of deforestation and forest degradation, as well as different degrees of institutional capacity to monitor, influence and regulate these drivers. 
Multiple sources of REDD finance are already available, or likely to become available. The amount and composition depends on the design of the REDD mechanism and will change over time. Currently, most REDD financing is earmarked for capacity building, or 'readiness' activities. Although the nature of the REDD mechanism is still under discussion, and the outcome will affect the financing needs and financial flows, we present a preliminary exploration of the potential financing streams for different country contexts and identify possible gaps in financing.

\subsection{What are the financing needs?}

Regardless of the final design of the REDD mechanism (Eliasch 2008, see Table 5.1) there are two basic needs for financing:

- Financing upfront capacity-building (readiness): Countries need to fulfil minimum readiness requirements, such as putting in place infrastructure for monitoring emissions reduction, clarifying land tenure and strengthening institutional capacities for law enforcement. One study estimates the costs of capacity building for 40 forest nations over a five-year period to be as much as USD 4 billion (Hoare et al. 2008). The amount and type of these costs will vary significantly between countries.

- Financing on-going emission reduction costs: Costs are in two categories: forest protection costs and opportunity costs. The first refers to the costs of implementing the policies and measures (PAMs) inside and outside the forest sector that are needed to reduce forest emissions. Examples include forest monitoring, reforming tenure, law enforcement, taxation of forestland, restrictions on road building and agricultural zoning. Opportunity costs, the second category, arise from foregone profits from deforestation or the costs of adopting more sustainable forest use. These costs vary from place to place and time to time. Opportunity costs are higher where markets are accessible and where expanding forest protection (e.g. REDD) intensifies agriculture. Nevertheless, low opportunity costs do not necessarily imply that REDD activities will be low cost. REDD activities often take place in areas where there are the greatest challenges in forest policy, administration and monitoring (Eliasch 2008). 
Table 5.1. Summary of REDD financing needs

\begin{tabular}{|c|c|c|c|}
\hline & \multirow{2}{*}{$\begin{array}{c}\text { Upfront capacity building } \\
\text { Readiness costs }\end{array}$} & \multicolumn{2}{|c|}{ Ongoing emissions reduction } \\
\hline & & $\begin{array}{l}\text { Forest protection } \\
\text { costs }\end{array}$ & $\begin{array}{l}\text { Opportunity } \\
\text { costs }\end{array}$ \\
\hline Objectives & $\begin{array}{l}\text { Upfront investments } \\
\text { in REDD infrastructure } \\
\text { (monitoring systems, } \\
\text { forest and carbon density } \\
\text { data), and stakeholder } \\
\text { participation }\end{array}$ & $\begin{array}{l}\text { Cover the cost } \\
\text { of implementing } \\
\text { policies and } \\
\text { measures (PAMs) } \\
\text { that enable and } \\
\text { promote REDD } \\
\text { investments }\end{array}$ & $\begin{array}{l}\text { Compensate for } \\
\text { forgone profits } \\
\text { from reducing } \\
\text { forest emissions }\end{array}$ \\
\hline Components & $\begin{array}{l}\text { - Upfront financing } \\
\text { - Little direct effect on land } \\
\text { use emissions } \\
\text { - Upfront transaction costs }\end{array}$ & $\begin{array}{l}\text { - Upfront financing } \\
\text { - Costs and } \\
\text { benefits depend } \\
\text { on policy } \\
\text { - Recurrent } \\
\text { transaction costs }\end{array}$ & $\begin{array}{l}\text { - Continuous } \\
\text { financing } \\
\text { - Costs vary } \\
\text { across space } \\
\text { and time }\end{array}$ \\
\hline Examples & $\begin{array}{l}\text { - Set up monitoring system } \\
\text { (USD 0.5-2 million, in } \\
\text { India and Brazil) } \\
\text { - Set up forest inventories } \\
\text { (USD } 50 \text { million for } 25 \\
\text { nations) } \\
\text { - Capacity-building (USD } 4 \\
\text { billion for } 40 \text { nations over }^{\mathrm{b}} \text { years) } \\
\text { - Land tenure reform } \\
\text { (size-dependent, USD\$ }^{\mathrm{a}} \\
4-20 \text { million over } 5 \text { years } \\
\text { for one country based on } \\
\text { estimates from Rwanda, } \\
\text { Ghana and Solomon } \\
\text { Islands) }\end{array}$ & $\begin{array}{l}\text { - Recurrent costs of } \\
\text { forest inventories } \\
\text { (USD 7-17 million } \\
\text { per year for } 25 \\
\text { countries) } \\
\text { - Monitoring legal } \\
\text { compliance }\end{array}$ & $\begin{array}{l}\text { - Opportunity } \\
\text { costs of } \\
\text { halving } \\
\text { deforestation } \\
\text { (USD } 7 \text { billion } \\
\text { annually } \\
\text { over } 30 \text { years } \\
\text { for eight } \\
\text { countries)c }\end{array}$ \\
\hline
\end{tabular}

${ }^{\mathrm{a}}$ Hoare et al. 2008; ${ }^{\mathrm{b}}$ Eliasch 2008; ${ }^{\mathrm{C}}$ Grieg-Gran 2008

\subsection{The forest context affects financing needs}

Pressures on forests vary across countries and regions, and over time. Human pressure on forests is shaped by, among other things, market access, the nature of forest use and security of tenure. Chomitz et al. (2006) have provided a stylised three-part typology of tropical forests: core areas beyond the agricultural frontier, forest edges and disputed areas, and forest-agricultural mosaic lands (Table 5.2). In essence, these forest types correspond to the three stages of the forest transition curve (Figure 5.1). 
Table 5.2. Three stylised forest types.

\begin{tabular}{|c|c|c|c|}
\hline & $\begin{array}{l}\text { Forest cores } \\
\text { beyond the } \\
\text { agricultural } \\
\text { frontier ( } 49 \% \text { of } \\
\text { tropical forests) }\end{array}$ & $\begin{array}{l}\text { Forest edges and } \\
\text { disputed areas } \\
\text { ( 37\% of tropical } \\
\text { forests) }\end{array}$ & $\begin{array}{l}\text { Mosaic lands ( 14\% } \\
\text { of tropical forests) }\end{array}$ \\
\hline Features & $\begin{array}{l}\text { - Remote from } \\
\text { markets; low } \\
\text { deforestation } \\
\text { - Low population, } \\
\text { but high } \\
\text { proportion of } \\
\text { indigenous and } \\
\text { poor }\end{array}$ & $\begin{array}{l}\text { - Rapid agricultural } \\
\text { expansion and high } \\
\text { deforestation } \\
\text { - Rapidly increasing } \\
\text { land values } \\
\text { (frontiers) } \\
\text { - Forest use conflicts } \\
\text { (disputed areas) }\end{array}$ & $\begin{array}{l}\text { - Depleted, } \\
\text { fragmented forests; } \\
\text { slower deforestation, } \\
\text { but higher } \\
\text { degradation } \\
\text { - High land values } \\
\text { and high population } \\
\text { densities with a } \\
\text { substantial portion } \\
\text { of forest dwellers }\end{array}$ \\
\hline $\begin{array}{l}\text { Policy } \\
\text { needs }\end{array}$ & $\begin{array}{l}\text { - Protecting } \\
\text { indigenous rights } \\
\text { - Averting } \\
\text { disorderly frontier } \\
\text { expansion } \\
\text { by equitably } \\
\text { assigning rights } \\
\text { - Regulated } \\
\text { infrastructure } \\
\text { expansion }\end{array}$ & $\begin{array}{l}\text { - Policing and law } \\
\text { enforcement, e.g. } \\
\text { to prevent resource } \\
\text { grabs } \\
\text { - Equitable } \\
\text { settlement of } \\
\text { claims } \\
\text { - Control of road } \\
\text { expansion }\end{array}$ & $\begin{array}{l}\text { - Enforcement of } \\
\text { property rights over } \\
\text { natural resources } \\
\text { - Developing markets } \\
\text { for environmental } \\
\text { services } \\
\text { - Reforming } \\
\text { regulations to } \\
\text { encourage forestry }\end{array}$ \\
\hline
\end{tabular}

Source: Chomitz et al. 2006

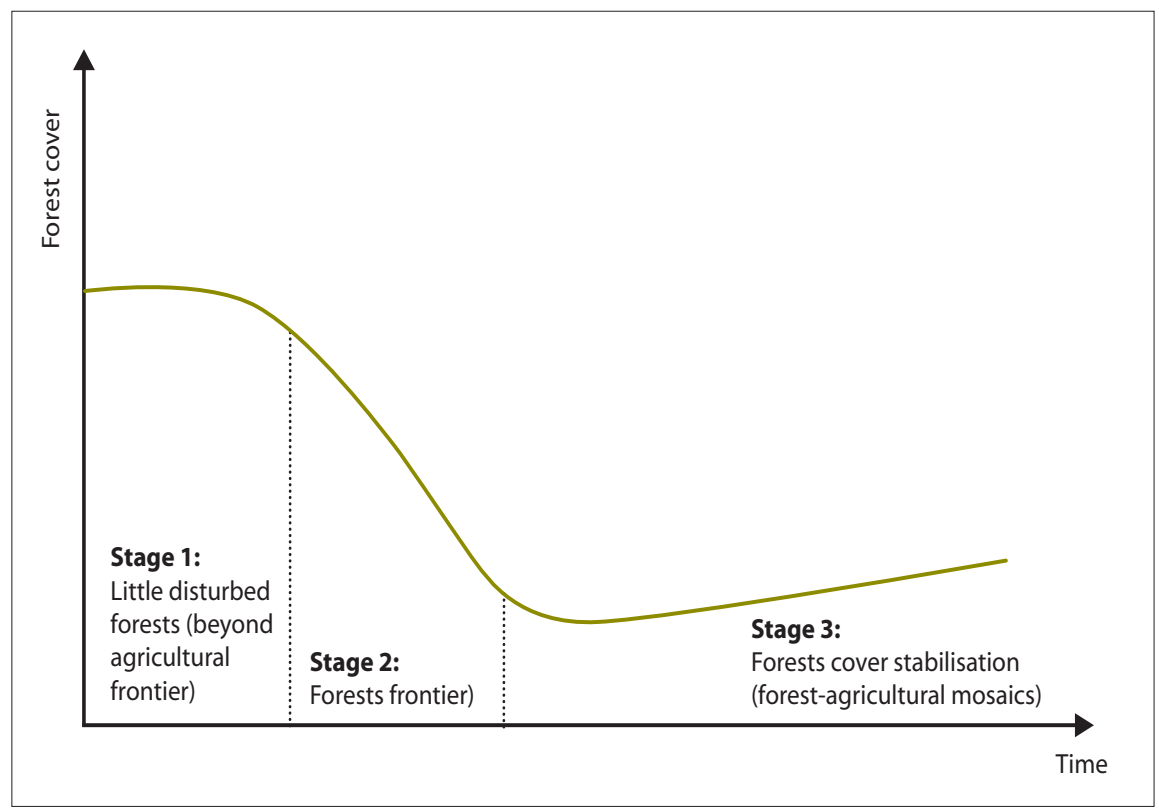

Figure 5.1. The forest transition curve 
It is estimated that forest frontiers, where deforestation is concentrated, are currently distributed almost evenly across all regions (Figure 5.2). Different policies may be needed to address the governance challenges, and associated deforestation and degradation, in different forest types. For example, policies that will be important for improving forest management in forest mosaic lands - where degradation is concentrated - may include enforcing property rights and creating new markets for environmental services (Table 5.2).

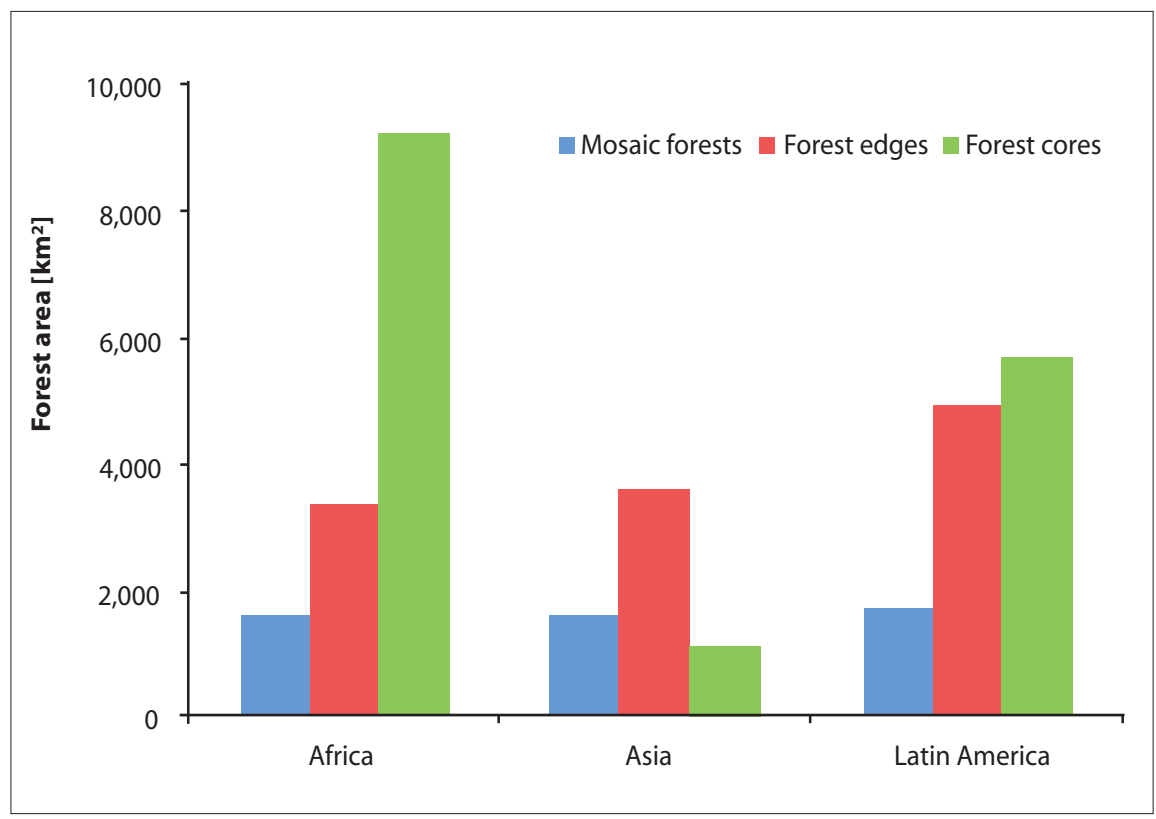

Figure 5.2. Approximate regional distribution of forest types Note: Rough proxies were used because it is impossible to map the stylised forest types. For the mosaic lands, only data on the forest portion was used.

Source: Chomitz et al. (2006) using global land cover data from 2000 (ECJRC 2003)

\subsection{Matching needs and finance}

Existing and potential sources of finance for REDD activities are both public and private (Table 5.3). Different sources suit different needs (Table 5.4). For example, the Organisation for Economic Co-operation and Development (OECD) does not classify public spending to acquire carbon credits as overseas development assistance (ODA). This is because these credits would count as ODA reflows (i.e. would have to be subtracted from ODA flows in the year they occur) (Dutschke and Michaelowa 2006). Activities that generate carbon credits will, therefore, have to be financed from the private sector and sales of REDD credits to Annex I governments for offsetting their national greenhouse gas (GHG) emissions. 
Table 5.3. Potential sources of finance for REDD

\begin{tabular}{|c|c|}
\hline \multicolumn{2}{|r|}{ Public finance } \\
\hline Type & Description \\
\hline $\begin{array}{l}\text { Traditional } \\
\text { ODA for } \\
\text { forestry }\end{array}$ & $\begin{array}{l}\text { - Increasing; has risen } 47.6 \% \text { since } 2000 \text { and totalled almost USD } 2 \\
\text { billion in 2005-07 (World Bank 2008) } \\
\text { - Provides grants, concessional loans, short-term financing for } \\
\text { specific projects and long-term programme financing or budget } \\
\text { support } \\
\text { - Also interested in co-benefits related to reducing poverty, } \\
\text { conserving biodiversity and improving governance }\end{array}$ \\
\hline $\begin{array}{l}\text { New ODA } \\
\text { for REDD }\end{array}$ & $\begin{array}{l}\text { - Recent emergence of new REDD-related financing mechanisms } \\
\text { that draw all or part of their revenues from international public } \\
\text { finance sources } \\
\text { - Includes finance aimed at 'pump priming' the private sector, such } \\
\text { as the World Bank's Forest Carbon Partnership Fund, and sources } \\
\text { aimed at building public-sector capacity, such as the Congo Basin } \\
\text { Fund }\end{array}$ \\
\hline Domestic & $\begin{array}{l}\text { - Limited domestic public financing for forestry from taxes and } \\
\text { royalties. } \\
\text { - Typically used for subsidies and other incentives } \\
\text { - Sponsors environmental services in forests }\end{array}$ \\
\hline \multicolumn{2}{|c|}{$\begin{array}{l}\text { Private sector and carbon market finance } \\
\text { (includes Annex I government purchases of REDD credits as offsets in carbon markets }\end{array}$} \\
\hline $\begin{array}{l}\text { Existing } \\
\text { carbon } \\
\text { market }\end{array}$ & $\begin{array}{l}\text { - Two components: voluntary and compliant (current compliance } \\
\text { market excludes REDD) } \\
\text { - Compliance market restricted to afforestation/reforestation } \\
\text { under the Clean Development Mechanism, which may or may not } \\
\text { become part of a future REDD mechanism } \\
\text { - Voluntary market dominates in forestry, making up } 18 \% \text { of all } \\
\text { projects globally in } 2007 \text { (Hamilton et al. 2007) }\end{array}$ \\
\hline $\begin{array}{l}\text { Future } \\
\text { carbon } \\
\text { markets }\end{array}$ & $\begin{array}{l}\text { Three main avenues under discussion: } \\
\text { i) integrating REDD into a global compliance carbon market; } \\
\text { ii) allocating auction proceeds; } \\
\text { iii) allocating revenues from other fees, fines and taxes } \\
\text { - Regional and domestic markets may also consider using REDD } \\
\text { crediting for compliance: e.g. the European Union emissions } \\
\text { trading scheme }\end{array}$ \\
\hline $\begin{array}{l}\text { Foreign } \\
\text { direct } \\
\text { investment }\end{array}$ & $\begin{array}{l}\text { - May constitute an important source, but investment is } \\
\text { concentrated in low-risk countries with profitable forest industries } \\
\text { - Flows to forest sector have increased by } 29 \% \text { from USD } 400 \text { million } \\
\text { in 2000-02 to USD } 516 \text { million in 2005-07 (World Bank 2008) }\end{array}$ \\
\hline Domestic & $\begin{array}{l}\text { Public-private partnerships or microcredit schemes. These are } \\
\text { unlikely to be significant, especially in least developed countries, } \\
\text { due to low level of resources, lack of expertise and difficulty in } \\
\text { raising finance from risk-averse domestic banks }\end{array}$ \\
\hline Non-profit & $\begin{array}{l}\text { - Represents growing proportion of international private finance } \\
\text { - Typically small, narrowly targeted grants; may not have wide REDD } \\
\text { applicability } \\
\text { - Non-profits are interested in REDD and may be less risk-averse } \\
\text { than profit-making enterprises }\end{array}$ \\
\hline
\end{tabular}


Public and private finance suit different forest types (Table 5.4). Public finance is extremely relevant for forests 'beyond the agricultural frontier' and in forest frontiers that have comparatively weak land tenure systems and governance structures. Private-sector finance could play a greater role in forest mosaic lands that have comparatively strong land tenure systems and good governance. However, forests in mosaic lands currently constitute the smallest share of tropical forests.

Table 5.4. Matching financial sources to forest types

\begin{tabular}{llll}
\hline & $\begin{array}{l}\text { Forests beyond } \\
\text { agricultural frontiers }\end{array}$ & Forest frontiers & $\begin{array}{l}\text { Forest mosaic } \\
\text { lands }\end{array}$ \\
\hline Public finance & $\begin{array}{l}\text { Significant need for } \\
\text { international and } \\
\text { domestic sources }\end{array}$ & $\begin{array}{l}\text { Important for } \\
\text { enabling REDD } \\
\text { investments }\end{array}$ & $\begin{array}{l}\text { Need depends } \\
\text { on governance } \\
\text { context }\end{array}$ \\
Private finance & $\begin{array}{l}\text { Less likely, as clear } \\
\text { land tenure required } \\
\text { for REDD-payments }\end{array}$ & $\begin{array}{l}\text { Likely, if enabling } \\
\text { environment for } \\
\text { REDD investments is } \\
\text { secured }\end{array}$ & $\begin{array}{l}\text { Highly likely, } \\
\text { if enabling } \\
\text { environment } \\
\text { for REDD } \\
\text { investments is } \\
\text { secured }\end{array}$ \\
\hline
\end{tabular}

\subsection{Public finance}

Upfront public finance is needed to create policy environments that enable the delivery of effective REDD outcomes, especially in weak governance contexts. ODA finance will be crucial to cover capacity building costs. Few developing countries have shown the ability or political will to finance this aspect of REDD. Even if REDD were integrated into the global carbon market, an additional USD 11-19 billion each year would need to be found from other sources - most likely ODA - to halve emissions by 2020 (Eliasch 2008).

Increasing donor interest in REDD has boosted the amount of ODA available for carbon forestry. Programmatic or budget support helps strengthen government institutions and increases ownership of REDD systems. Where carbon returns are guaranteed, financing can be provided through loans. Support for capacity building can be channelled through technical assistance ODA.

But ODA is arguably a short-term solution; the recent increase in forestryrelated ODA to almost USD 2 billion (2005-07) represents only a tiny fraction of the USD 11-19 billion recommended in the Eliasch review. Thus, ODA must be deployed strategically to stimulate and complement private investment. This means supporting basic readiness requirements and enabling 
investments. Investments to leverage private investments are particularly important in high-risk countries where little private-sector finance is available. However, ODA financing for forestry has a tendency to gravitate towards safer environments, such as South and Southeast Asia and the Americas, rather than to Africa (World Bank 2008).

The likely dependence of REDD on ODA, especially for creating new international funds to support REDD, raises some concerns about how such efforts should be structured. These include:

- Lack of harmonisation among initiatives, which may create added burdens for resource-stretched governments

- Lack of alignment with government systems and the low absorptive capacity of governments to use the funds efficiently

- Risk of diverting ODA from other areas, such as health and education

These harmonisation and alignment concerns mirror the concerns across the aid sector that led to the Paris Declaration on Aid Effectiveness (OECD 2005).

\subsection{Carbon market finance}

Carbon finance can mobilise more and longer-term funding than ODA, especially when greenhouse gas offset markets offer the incentive to trade carbon credits. Carbon investments are more likely in countries with strong governance structures and well-defined tenure systems. National verification systems, or certification schemes, may also attract investment. The level of private financing depends on several factors, including:

- Long-term GHG emissions reduction commitments

- Carbon credits from sub-national approaches in the REDD scheme

- Early action to generate REDD credits that can be banked towards compliance with post-2012 targets

The voluntary carbon market is a useful testing ground for different approaches to REDD, but is unlikely to generate sufficient financing for large REDD initiatives. Emerging financial mechanisms, such as Forest Backed Bonds (tradable financial instruments backed by forest-related assets), could also be new sources of capital (Petley 2007). 
International carbon markets are an attractive source of funds for REDD because they could potentially mobilize significant amounts of financing in the long run. The main options currently being discussed in the REDD debate are: (i) integrating REDD into a global carbon market; (ii) allocating auction proceeds to a REDD fund; and (iii) allocating revenues from other fees, fines and taxes to a REDD fund.

\subsubsection{Integrating REDD into global carbon markets}

The largest potential for REDD finance is in carbon market mechanisms that convert emissions reductions from REDD initiatives into carbon credits that industries and countries can use to comply with emissions commitments.

The amount generated by tradable credits for REDD depends on several factors. These include the depth of Annex I emission budgets, fungibility of REDD credits in the carbon markets and other details of the REDD architecture. Fungibility refers to the type and degree of integration of REDD into existing carbon markets. There are fears that full fungibility will flood carbon markets with REDD credits, assuming that these credits will be cheaper than credits from other mitigation activities. This is not necessarily the case (see Chapter 3 of this book). On the one hand an oversupply of cheap carbon credits could reduce carbon prices and remove incentives for further REDD activities. On the other hand, the acceptance of REDD credits as a compliance tool creates demand for further REDD activities. One study shows that REDD credits, even when unrestricted market access is assumed, would be highly unlikely to swamp the carbon market. Allowing all forest credits into the market is only likely to bring carbon prices in 2020 down from USD 35 to USD 24 (Piris Cabezas and Keohane 2008). The Eliasch (2008) review also concludes that the fear that markets will be flooded seems exaggerated. Carbon traders, several Latin American countries and Indonesia support full fungibility (see Table 5.5).

A number of proposals address the risk of flooding the market and thereby endangering environmental integrity (Table 5.5). These include adopting deeper targets, controlling fungibility of REDD credits in a 'dual market' (Ogonowski et al. 2007) and creating a new trading unit specific for REDD (Hare and Macey 2007). 
Table 5.5. Proposals for fungibility of REDD credits in carbon markets

\begin{tabular}{|c|c|c|}
\hline Proposal & Description & Type \\
\hline $\begin{array}{l}\text { Full fungibility } \\
\text { (country } \\
\text { proposals incl. } \\
\text { Belize, Chile, } \\
\text { Indonesia et al.) }\end{array}$ & $\begin{array}{l}\text { REDD credits are sold as offsets to } \\
\text { Annex } 1 \text { countries. Demand for } \\
\text { REDD arises from because REDD } \\
\text { credits are comparatively cheap. } \\
\text { Capping the amount of credits } \\
\text { allowed in systems is possible }\end{array}$ & $\begin{array}{l}\text { Fully fungible REDD } \\
\text { coupled with deeper } \\
\text { emissions reduction } \\
\text { targets by Annex B } \\
\text { countries, resulting in } \\
\text { higher demand for credits }\end{array}$ \\
\hline $\begin{array}{l}\text { Dual markets } \\
\text { (Center for Clean } \\
\text { Air Policy - CCAP) }\end{array}$ & $\begin{array}{l}\text { Creates a separate REDD trading } \\
\text { scheme; demand generated by } \\
\text { transferring a share of Annex I } \\
\text { commitments to the new market } \\
\text { (amount depends on overall } \\
\text { Annex I targets) }\end{array}$ & $\begin{array}{l}\text { Separate, but linked } \\
\text { market - transfers some } \\
\text { commitments from } \\
\text { current market to REDD } \\
\text { market. Fungibility may } \\
\text { increase as REDD market } \\
\text { matures }\end{array}$ \\
\hline $\begin{array}{l}\text { Tropical } \\
\text { Deforestation } \\
\text { Emission } \\
\text { Reduction } \\
\text { Mechanism } \\
\text { (TDERM) } \\
\text { (Greenpeace) }\end{array}$ & $\begin{array}{l}\text { Introduction of a new trading } \\
\text { 'unit' (Tropical Deforestation } \\
\text { Emission Reduction Unit/ } \\
\text { TDERU). TDERUs will be used by } \\
\text { Annex } 1 \text { countries to fulfil part } \\
\text { of their reduction targets. For } \\
\text { predictability of revenue flows, } \\
\text { levels of TDERU purchases would } \\
\text { be set. A maximum would also be } \\
\text { set to prevent large-scale offsets }\end{array}$ & $\begin{array}{l}\text { Separate, but linked } \\
\text { market - transfers some } \\
\text { commitments from } \\
\text { current market to REDD } \\
\text { market }\end{array}$ \\
\hline
\end{tabular}

\subsubsection{Allocation of auction proceeds to a REDD fund}

Another way to raise funds is to auction allowances from emission-trading schemes, and allocate some of the proceeds to a global REDD fund. The WarnerLieberman Bill (US), and EU Climate and Energy Package, foresee diverting some of the proceeds from auctioning allowances to support REDD.

The European Commission is considering earmarking 5\% of auction proceeds from the European Union Emissions Trading Scheme after 2012 for global efforts to combat deforestation. This would generate an estimated USD 2.0-2.7 billion a year by 2020 (EC 2008). Germany recently pledged to invest all the money it raises from auctioning EU allowances into domestic and international climate activities and policy interventions. These auctions raise significant resources. In Germany alone, proceeds of auctions reach more than EUR 1 billion annually. Auctioning allowances for international aviation and marine emissions could raise an estimated USD 40 billion (Eliasch 2008). An auction of all industrialised countries' emissions could raise at least EUR 100 billion annually (Dutschke 2008). But, it is uncertain what proportion of the proceeds of these auctions would be channelled to REDD, as there will be competing claims from other sectors and mechanisms, such as technology transfer and adaptation. 
Some UNFCCC proposals (CAN-International, Norway) promote the auction of emissions allowances at the international level (i.e. assigned amount units (AAU) of the Kyoto protocol system) as an additional way to leverage funds for REDD. ${ }^{1}$ By decoupling REDD from the overall reduction targets these proposals reduce the risk of flooding the market. A critical question, however, is how to ensure that these auction proceeds will effectively be earmarked for REDD purposes.

\subsubsection{Allocation of revenues from other fees, fines and taxes}

A third proposal is to allocate taxes and levies to a REDD funding mechanism. These could be linked to carbon markets or come from other markets. Current options include:

- Imposing a fee on the transfer of assigned amount units (AAUs) for Parties to the Kyoto Protocol or other activities/sectors;

- Paying fines from non-compliant countries into a compliance fund.

Levying a fee on a Clean Development Mechanism (CDM) or other carbon project at the international level is comparable to the $2 \%$ levied on CDM transactions to support the UNFCCC Adaptation Fund. Such a system could also be applied at the national level. China, for example, established a system of tiered taxation of CDM projects to redirect finance from large industrial CDM projects towards initiatives that have more impact on sustainable development (Muller 2007). Other options include a levy on international air travel, which could generate revenues of USD 10-15 billion, or a tax on wholesale currency transactions (Tobin tax), which could raise about the same amount (Eliasch 2008).

These mechanisms could raise substantial amounts of funding, but have their drawbacks from efficiency, effectiveness or equity perspectives - notably as regards allocating revenues equitably among countries and sectors. Taxes and fees affect the supply and demand of emissions reductions activities. On the demand side, imposing fees on Annex I countries to purchase AAUs, for example, may divert budget allocations away from other areas.

Additionally, some of these proposals could be politically difficult. For example, fines for non-compliance would go much further than the 'soft' enforcement mechanisms of the Kyoto Protocol Compliance Committee. They would be unique as multilateral environmental agreements traditionally have weak compliance systems.

1 While emission allowances in the EU carbon market are already auctioned in part, allocation of AAUs to the countries under the Kyoto Protocol is free of charge. According to CAN-International, selling AAUs at a price of USD 30-40 a piece would raise USD 3.75 billion for every $1 \%$ of AAUs sold. Selling a fraction of AAUs, e.g. 20-30 \%, would result in a total of USD 75-112.5 billion a year which would then be available for adaptation, REDD and technology transfer (Scholz and Schmidt 2008). 


\subsection{Addressing the financing gaps}

Exploiting the full potential of REDD requires funding at unprecedented levels and is among the main challenges in REDD. Financing shortfalls are likely in: (i) the demonstration period for the international REDD mechanism prior to 2012; and (ii) in countries where forest governance is weak and, thus, where the investment environment is high risk - as is the case in most tropical forestlands.

ODA could support countries with restricted access to the REDD market. This would improve international equity. By designing appropriate mechanisms, financing gaps may also be addressed. Good examples of appropriate mechanisms are rewarding early action (which will be crucial for attracting early and highrisk private investment), and giving credit for REDD policies and measures (PAMs). These kinds of measures could reduce any perverse incentives that may encourage countries to step up deforestation before 2012. Market-linked mechanisms, such as including REDD credits in the carbon market, auctioning emission allowances and/or fees and taxes on carbon transactions, are the most promising avenues for addressing financing shortfalls.

Whatever the scenario, we need to find ways to make up the shortfall in financing from both public and private sources. Above all, a future REDD mechanism should be open to flexible and creative financing approaches, so it can adapt to countries' changing needs and experiences. 


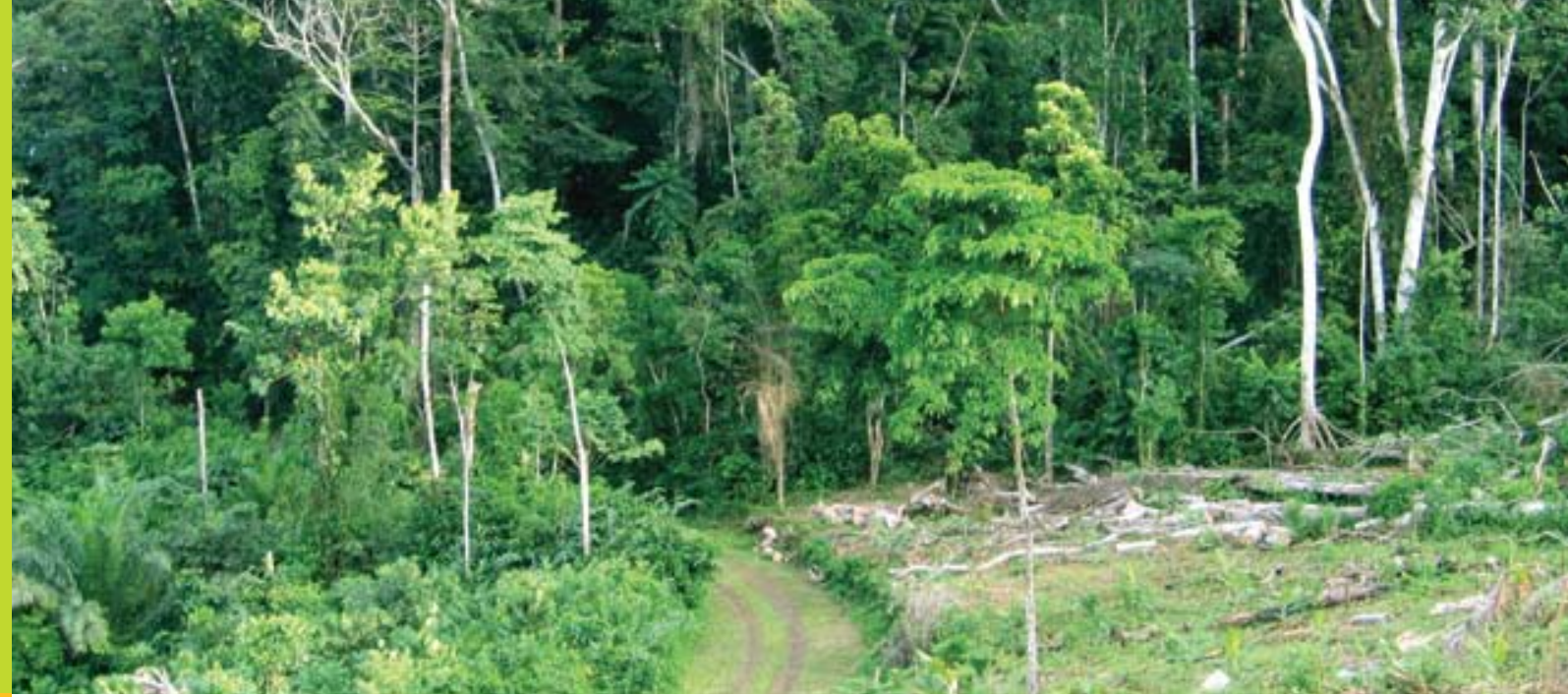

\section{Chapter 6}

\section{How do we set the reference levels for REDD payments?}

Arild Angelsen

\subsection{The issue}

Among the most critical elements of a new global 'reducing emissions from deforestation and forest degradation' (REDD) regime is how to set national baselines or reference lines/levels. ${ }^{1}$ Reference levels have profound implications for the environmental effectiveness, cost efficiency, and distribution of REDD funds among countries. Yet, there is no agreed-upon 'formula' for how to set them. Most REDD submissions to the United Nations Framework Convention on Climate Change (UNFCCC) suggest using historical deforestation, but many countries do not have reliable data on that. Similarly, there is strong support for including 'national circumstances', but the practical implications of that are yet to be worked out. Some might, due to the problems involved, 'throw up their hands in despair at the idea of working out baselines' (Pearce 2007: 2). But there is no escape; the unavoidable question is when (and how) to start crediting emission reductions.

\footnotetext{
1 In some instances 'baseline' is used to refer to the clean development mechanism (CDM), while 'reference line/level' refers to REDD, a distinction not used in this chapter. Rather we apply the distinction between Business as Usual (BAU) and crediting baselines outlined here, and use 'baseline' in both, while the term 'reference line/level' is used in the meaning of crediting baseline.
} 
The debate is also obfuscated by terminology, as the terms 'baseline' and 'reference line/level' refer to at least three different things. These are illustrated in Figure 6.1. First, baseline can refer to the historical baseline, that is, the rate of deforestation and degradation (DD) and the resulting $\mathrm{CO}_{2}$ e emissions over the past $\mathrm{x}$ years. Second, baseline can refer to the projected business as usual (BAU) scenario: how would emissions from DD evolve without the REDD activity? Third, baseline can refer to the crediting baseline (i.e. like an emissions quota). A BAU baseline is the benchmark for judging the impact of the REDD measures implemented (and ensuring additionality), while the crediting baseline is the benchmark for rewarding the country (or project) if emissions are below that level or not giving any reward or possibly invoking debits if emissions are higher (see Chapter 8 on liability).

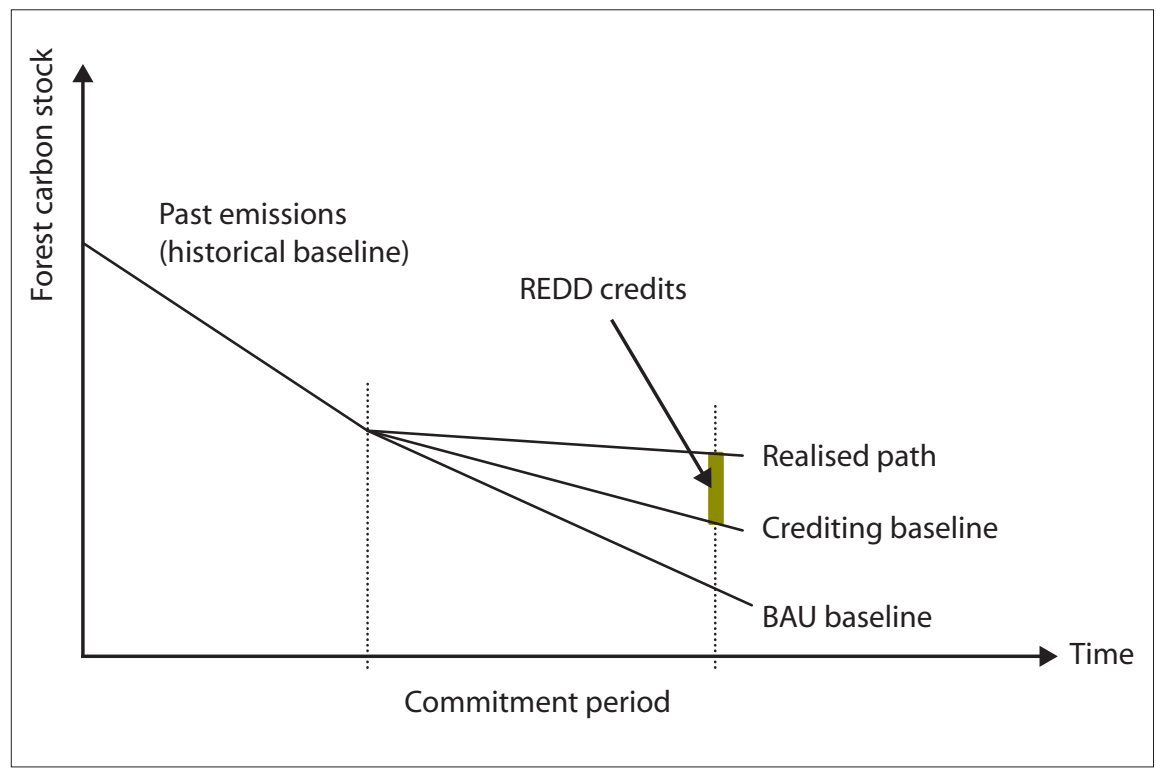

Figure 6.1. BAU and crediting baselines

This chapter therefore makes a distinction between historical baseline, $B A U$ baseline, and crediting baseline. Although a distinction between BAU and crediting baselines is not made explicitly in submissions, it is useful to assess the arguments from two different angles: (i) Are they good predictors of future deforestation and degradation (BAU)? This could, in principle, be answered by scientists based on current knowledge on causes of DD; and (ii) Are these acceptable reasons for setting the crediting baseline? The latter is largely a political question, going well beyond the technical issues. 


\subsection{The business as usual (BAU) scenario}

\subsubsection{Historical national deforestation}

The BAU scenario tries to answer the counterfactual and hypothetical question: what would deforestation be without REDD? Almost all submissions by the Parties, as well as the Bali Action Plan (COP 13), suggest that baselines should include historical national deforestation. The reference period is typically set to the average deforestation rate of the last 10 years, and updated every 3 years, as suggested in an early proposal by Santilli et al. (2005). The exact reference period may differ and some flexibility will be needed, for example, based on the availability of national forest inventories. But the choice of historical reference period can have dramatic impacts on the BAU scenario, and countries might strategically opt for reference periods that maximise REDD transfers.

How good is past deforestation to predict the future one? First, due to poor time series data for most developing countries, we do not know as much as we would like to know. Second, what we know suggests that past deforestation is not a precise predictor of future deforestation (New Zealand submission, April 2008). Unlike emissions from fossil fuels, which are closely linked to one variable (gross domestic product, or GDP), deforestation is 'multicausal' and can be highly variable from year to year. It can also show systematic trends over longer periods (5-10 years) which depart from past deforestation. Annual fluctuations are of less concern and can be addressed by, for example, using running averages (e.g. last three years) or mechanisms to address nonpermanence and liability (see Chapter 8).

The more serious issue is when historical deforestation systematically underor overestimates the rate of deforestation in a BAU scenario. The forest area (change) may follow a pattern suggested by the forest transition (FT) theory (Mather 1992; Angelsen 2007): initially, the country is characterised by a high percentage of land under forest cover and a low rate of deforestation. Then deforestation accelerates, slows down, forest cover stabilises and eventually starts recovering. This pattern is illustrated in Figure 6.2. Some countries at early stages in this transition, such as Papua New Guinea and the Democratic Republic of Congo, can be expected to have high forest area values and low, but accelerating, deforestation rates. Others in the middle of the transition, such as parts of Indonesia and Brazil, will have high rates, but these are expected to slow down as forest is getting scarcer. Finally, countries late in the forest transition, such as China and India (and a number of high-income countries), have increasing forest areas. 


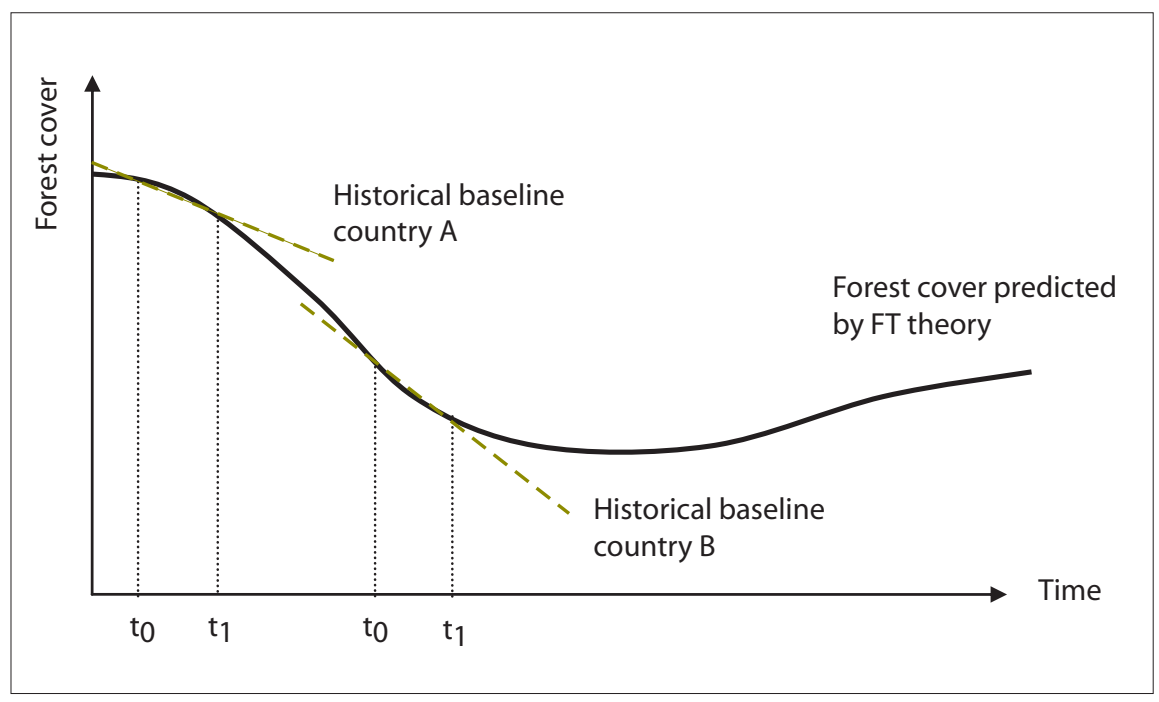

Figure 6.2. The forest transition and historical baselines

FT is not a 'law of nature', and the exact pattern is influenced by national context, global economic forces and government policies. Yet, it depicts a broad trend. Figure 6.2 illustrates the problem of setting baselines based on historical deforestation only. An extrapolation of historical rates underestimates future BAU deforestation for counties at the early stages in the transition, while it overestimates BAU deforestation for countries at the later stages. ${ }^{2}$

\subsubsection{National circumstances}

The second element of baseline-setting suggested in the Bali Action Plan (and several submissions) is to take 'national circumstances' into account. There is still a need to identify which factors constitute legitimate national circumstances (cf. Canada submission, March 2008). One prominent proposal in the debate (e.g. by Coalition for Rainforest Nations) is to include a development adjustment factor (DAF). A practical application of this might be that countries with low levels of GDP per capita will get more generous baselines, which may be justified by several arguments: (i) the poorest countries are presumably at an earlier stage in FT, and therefore deforestation (and degradation) is likely to accelerate rather than slow down in a BAU scenario; (ii) the capacity to implement REDD may be inversely related to GDP per capita, and larger transfers are needed; (iii) based on the UNFCCC principle of 'common but differentiated responsibilities' the REDD requirements should be lower for the poorest countries; and (iv) REDD should contribute to a transfer of resources to the very poorest countries (co-benefits).

2 Note that the forest transition describes changes in forest area, while we are interested in changes in forest carbon stocks. At early stages carbon-rich forests tend to be lost, while the increase at later stages tends to have lower carbon densities (tons carbon per hectare). 
An extension of the proposal to include national circumstances is to use more elaborate models to predict deforestation based on country-specific factors. The literature on cross-country deforestation regression models has included a number of variables, and some of these are potential candidates for inclusion in a formula for setting baselines (Angelsen and Kaimowitz 1999). These factors include population density and growth, forest area, economic growth, commodity prices, governance variables, and location (tropical and regional).

One problem with the modelling approach is that it is based on predicted values of, for example, population and economics growth and commodity prices. An extension of this approach, suggested by Motel et al. (2008) is to estimate the impact of government policies ex-post, that is, at the end of the crediting period when that information is available. Countries then get rewarded for good policies and efforts ('Compensated Successful Effort').

The modelling approach raises several issues. First, for most countries the time series data needed are poor or nonexistent. Second, deforestation modelling history suggests that cross-country models are not robust, i.e. no clear answer can be expected. Third, it is questionable whether a 'black box' baseline figure will be acceptable to the parties.

\subsubsection{Historical global deforestation}

Another option, originally put forwards in the Joint Research Centre proposal of Achard et al. (2005), is to use historical global deforestation rates to set individual country baselines. They suggested that countries with a rate of deforestation lower than half the global average use that as a national baseline, while countries with a higher deforestation rates use a national historical baseline. Different scenarios can also be generated by differing the weights put on historical global deforestation and national deforestation (cf. Strassburg et al. 2008).

The inclusion of global deforestation in setting national baselines is based on two critical assumptions. First, it is assumed that differences in rates of deforestation reflect differences in policies, and countries should not be rewarded (punished) for bad (good) policies by getting higher (lower) baselines. Indeed, a central element in many submissions is to 'reward early action'. While policies are important, for most countries experiencing low deforestation this is primarily a result of other factors, for example, stage in FT driven by economic development and forest scarcity, rather than deliberate conservation policies (Rudel et al. 2005).

Second, the proposal assumes some global convergence in deforestation rates, and that 'over the long run all developing countries would deforest at the average global rate' (Eliasch 2008: 136). This is equally problematic and lacks 
empirical evidence to support it. On the contrary, the evidence tends to favour the theory of FT (Rudel et al. 2005; Chomitz et al. 2006), in which case there is no global convergence, but rather distinct phases of forest cover change and slowly increasing forest cover characterising the last stage.

\subsection{Crediting baselines}

The BAU baseline is the benchmark to assess the impact of REDD policies and measures, while the crediting baseline is the benchmark to reward the country (or project) with REDD credits or other forms of payment. One might, of course, decide to set the crediting baseline equal to the BAU baseline, which is indeed the implicit assumption commonly made. But the distinction between the two is conceptually important, although by doing so one steps into one of the most contentious issues in climate negotiations: to what extent should developing countries bring an own, uncredited REDD contribution to a future climate agreement?

There are three major reasons for not equating the BAU baseline and the crediting baseline. First, an overall aim of the UNFCCC process is to limit global greenhouse gas (GHG) emissions compared with a BAU scenario. The emissions reduction responsibility assigned to different countries (and reflected in their crediting baselines) must, unavoidably, add up to the global target. Second, there is a genuine fear that including REDD credits into the compliance (offset) market will flood that market, i.e. lower the carbon price and crowd out other mitigation activities (see Chapters 3 and 5 for a further discussion). Setting the crediting baseline tighter than the BAU baseline will reduce the number of credits brought to market. Third, some of the reductions might be achieved through policies and measures (PAM) and non-market approaches funded by ODA.

Some policy reports such as the Eliasch Review (2008) suggest a soft entry for REDD into a climate agreement, based on no-lose and limited liability, and then gradually increasing commitments. This is also reflected in a Greenpeace submission (March 2008), which suggests increasing responsibility of REDD countries to reduce emissions as their economic circumstances and the global climate regime evolve.

\subsubsection{No-lose systems}

One option to ensure REDD country participation is to initially develop crediting baselines around a 'no-lose' system, similar to the 'sectoral no-lose targets' proposed by Ward et al. (2008) and others. The no-lose assumption is underlying much of the current REDD negotiations (although rarely explicitly stated using that term). 
What does 'no-lose' mean in practical terms? Obviously, a crediting line set equal to the BAU scenario, and with no liability ('baseline and credit') would be 'loss proof' for REDD countries. But this is just a sufficient and not a necessary condition. REDD countries may still have net benefits from participating in systems with crediting lines that are tighter than the BAU scenario, as explained in Box 6.1. The reason is as follows: REDD countries have an incentive to reduce deforestation up to the point where the marginal cost of reductions (i.e. the national supply curve of REDD) is equal to the international compensation, for example, the market price for REDD credits.

\section{Box 6.1. 'No-lose' crediting baselines}

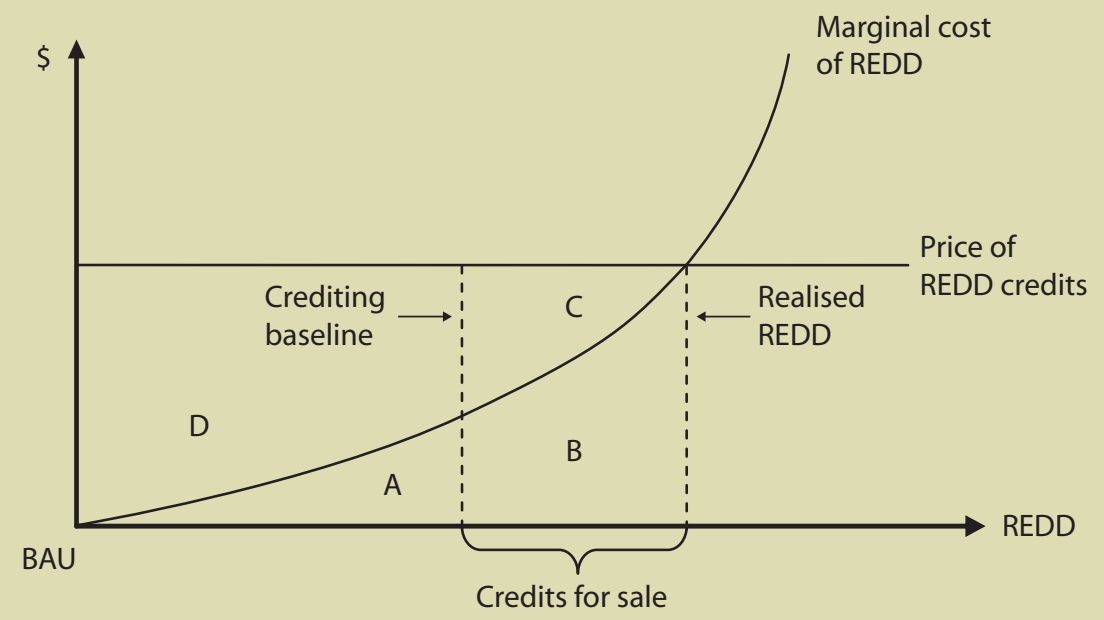

The marginal costs of reducing deforestation and degradation starts at zero in the BAU scenario, and they increase as reductions become more costly (e.g. increasingly profitable agricultural land uses are being excluded). Given an international price for REDD credits, the country will reduce emissions up to the point where the marginal costs equal that price (realised REDD). The total cost of these reductions is equal to the area $A+B$. A crediting baseline is given, and the country receives revenue from selling REDD credits for reductions beyond the crediting baseline, i.e. equal to the area $B+C$. Thus, the country's net gain equals $C-A$. If the crediting baseline is set equal to $\mathrm{BAU}$, the country will gain the area $\mathrm{C}+\mathrm{D}$, which can be termed the $R E D D$ rent.

A key question is how large the crediting baseline must be in order for the country to have a positive net gain. If the marginal cost curve is linear, the answer is that the crediting baseline must be more than one half realised REDD. But empirical studies show that the marginal cost curve for REDD is convex, as illustrated in the figure. Thus the crediting baseline can be set further to the right, i.e. it can be less than one half realised REDD, and the country still benefits. 
But for the initial and cheapest emission reductions that price is higher than the costs, which generates what may be termed a $R E D D$ rent (area $\mathrm{C}+\mathrm{D}$ in the figure). Because of this rent, a country can get a positive net benefit even if some of the initial reductions are not paid for, that is, the crediting line can be tighter than the BAU line. Thus 'no-lose' crediting baselines can imply some uncredited emissions reduction.

\subsection{2 'Common but differentiated responsibilities'}

The Bali Action Plan includes the principle of 'common but differentiated responsibilities', a long-standing UNFCCC principle also included in some REDD submissions (e.g. Papua New Guinea, August 2008). As noted before, the proposal of a DAF, where crediting baselines are set more favourably for the poorest countries, can be seen as a practical application of this principle to 'allow for certain amounts of deforestation to occur for the purpose of a country's socio-economic development' (Alvardo and Wertz-Kanounnikoff, 2007: 15).

The practical implications of this principle remain to be worked out. One possible inference of this principle is that every country has a responsibility, i.e. should bring some uncredited efforts to the negotiation table, while rich countries should bring more to the table. The exact implications will be the subject of intense late-night negotiations, and are not discussed further.

\subsubsection{Further refinements}

Given the uncertainty of setting baselines, one practical approach suggested by Schlamadinger et al. (2005) is to use a corridor approach with an increasing percentage of the reductions being credited. For example, a reduction in deforestation and degradation from $0.8 \%$ to $0.7 \%$ per year (or the equivalent in GHG emissions) gives carbon credits worth only $20 \%$ of the estimated emissions reductions, while reductions from $0.7 \%$ to $0.6 \%$ give credits equivalent to $40 \%$ of the estimated reductions, and so on.

Deforestation and degradation that occurs as a result of natural processes and events, e.g. hurricanes, should also be kept outside the crediting. This would be in line with the definition of deforestation as the direct, human-induced conversion of land from forest to non-forest (UNFCCC Decision 11/CP7). At the same time, an agreement should provide incentives for better managing 'seminatural' risks such as fire. 


\subsection{Assessment based on the 3E criteria}

The 3E criteria for assessing various proposals of REDD models include their carbon effectiveness, cost efficiency and equity and co-benefits (see Chapters 2 and 11). The effectiveness and efficiency arguments are mainly the same, thus these are collapsed in Table 6.1.

Table 6.1. Assessment of proposals based on effectiveness/efficiency and equity

\begin{tabular}{lll}
\hline & Effectiveness/efficiency & $\begin{array}{l}\text { Equity (international } \\
\text { distribution) }\end{array}$ \\
\hline $\begin{array}{l}\text { Historical national } \\
\text { deforestation }\end{array}$ & $\begin{array}{l}\text { Low-deforestation (and } \\
\text { forest-rich) countries may } \\
\text { opt out of an agreement }\end{array}$ & $\begin{array}{l}\text { Poor and forest-rich } \\
\text { countries to lose, others to } \\
\text { gain }\end{array}$ \\
$\begin{array}{l}\text { Historical global } \\
\text { deforestation }\end{array}$ & $\begin{array}{l}\text { Risk of hot air from low- } \\
\text { deforesting countries }\end{array}$ & $\begin{array}{l}\text { High-deforesting countries } \\
\text { to lose, low-deforestation } \\
\text { countries to gain }\end{array}$ \\
\hline $\begin{array}{l}\text { National circumstances } \\
\text { (country-specific factors) }\end{array}$ & $\begin{array}{l}\text { May improve effectiveness } \\
\text { if done well }\end{array}$ & $\begin{array}{l}\text { Depends on which factors } \\
\text { are considered }\end{array}$ \\
& $\begin{array}{l}\text { Risk of lower overall } \\
\text { reductions }\end{array}$ & $\begin{array}{l}\text { Some (poor?) countries } \\
\text { unable to negotiate } \\
\text { favourable baselines }\end{array}$ \\
\hline $\begin{array}{l}\text { Development adjustment } \\
\text { factor (higher crediting } \\
\text { lines for poor countries) }\end{array}$ & $\begin{array}{l}\text { More attractive for poor } \\
\text { country participation }\end{array}$ & Benefits poorest countries \\
\hline
\end{tabular}

The baselines have implications for effectiveness in a number of ways. If they are set too tight, a country may consider the net benefits too small and too uncertain to participate. For example, if countries at the early stages in FT (low deforestation and forest rich) are not given a crediting baseline above historical rates of emission, the incentive to participate will be smaller. More generally, giving out more generous baselines may be needed to buy broader participation, but also increases the risk of giving out 'tropical hot air' (below).

Another way in which crediting lines have effectiveness implications is through the impact on the global market of carbon credits (assuming REDD credits are allowed to enter that market). Many environmental nongovernmental organisations (e.g. Leach, 2008) point to the risk of 'market flooding' by supposedly cheap REDD credits. This is indeed a possible scenario, but the means for avoiding that are also readily available: (i) reduce supply of REDD credits by tightening baselines; (ii) increase demand by simultaneously introducing REDD credit and imposing tighter global targets for GHG emissions reductions (mainly demand from Annex I countries); and (iii) introduce managed (limited but gradually increasing) fungibility, e.g. a gradually expanding cap on REDD credits put on the market (Chapter 5). 
The second option is indeed a major argument for including REDD in a new climate agreement: by introducing a low-cost mitigation option, global targets can become more ambitious.

A related fear is for 'tropical hot air', that is, REDD credits that do not reflect any additional efforts being put on the market. One should note that 'hot air' is not created by inclusion of low-cost emissions reductions as such, but only to the extent that crediting baselines for emissions are inflated and set above the BAU baselines (no additionality). The risk is real that a large number of criteria for setting baselines (e.g. various national circumstances) may result in such inflated baselines, undermining the effectiveness of the system as well as its long-term credibility.

Similarly, using global deforestation rates to set national baselines entails a high risk of creating 'hot air' from low-deforesting countries. Many are likely to receive crediting baselines above their emissions in a BAU scenario, while REDD buyers expect to pay for real reductions.

The distributional implication of different criteria for setting baselines is large. Simple back-of-the-envelope calculations suggest that the difference for some of the largest tropical forests countries may be several billions of US dollars per year, which is also shown in scenarios for various methods of baseline setting (e.g. Strassburg et al. 2008).

Allocating baselines based solely on historical national rates of deforestation may make income-poor and forest-rich countries (at the early stage in FT) lose out. Using global historical rates may make high-deforesting countries (in the intermediate stage in that transition) lose out. Including a DAF would benefit the poorest countries and make the REDD mechanism more pro-poor.

\subsection{Conclusion}

Baselines are critical elements of a new REDD regime, for both overall effectiveness and international distribution and equity. There are clear conflicts of interest among (groups of) countries, and (partly for that reason) the question is politically sensitive. Almost all submissions use historical deforestation as the point of departure, and most also suggest that 'national circumstances' and 'rewarding early action' be taken into account. These principles remain to be operationalised. One step forwards in the debate is to better distinguish between the two types of baselines discussed in this chapter: (i) the prediction of deforestation and degradation in a BAU scenario; and (ii) the crediting baseline, which will be based on the BAU plus a set of political considerations, as well as the country's strength at the negotiation table. 
A key dilemma facing negotiators is that generous baselines, based on 'country-by-country' assessments to take national circumstances into account, may create 'hot air', which undermines the environmental integrity (overall reductions in GHG emissions) and the credibility of REDD. On the other hand, tight crediting baselines may make an agreement unacceptable for REDD countries. In short, the balancing act is between the risk of 'tropical hot air' and participation of REDD countries. 



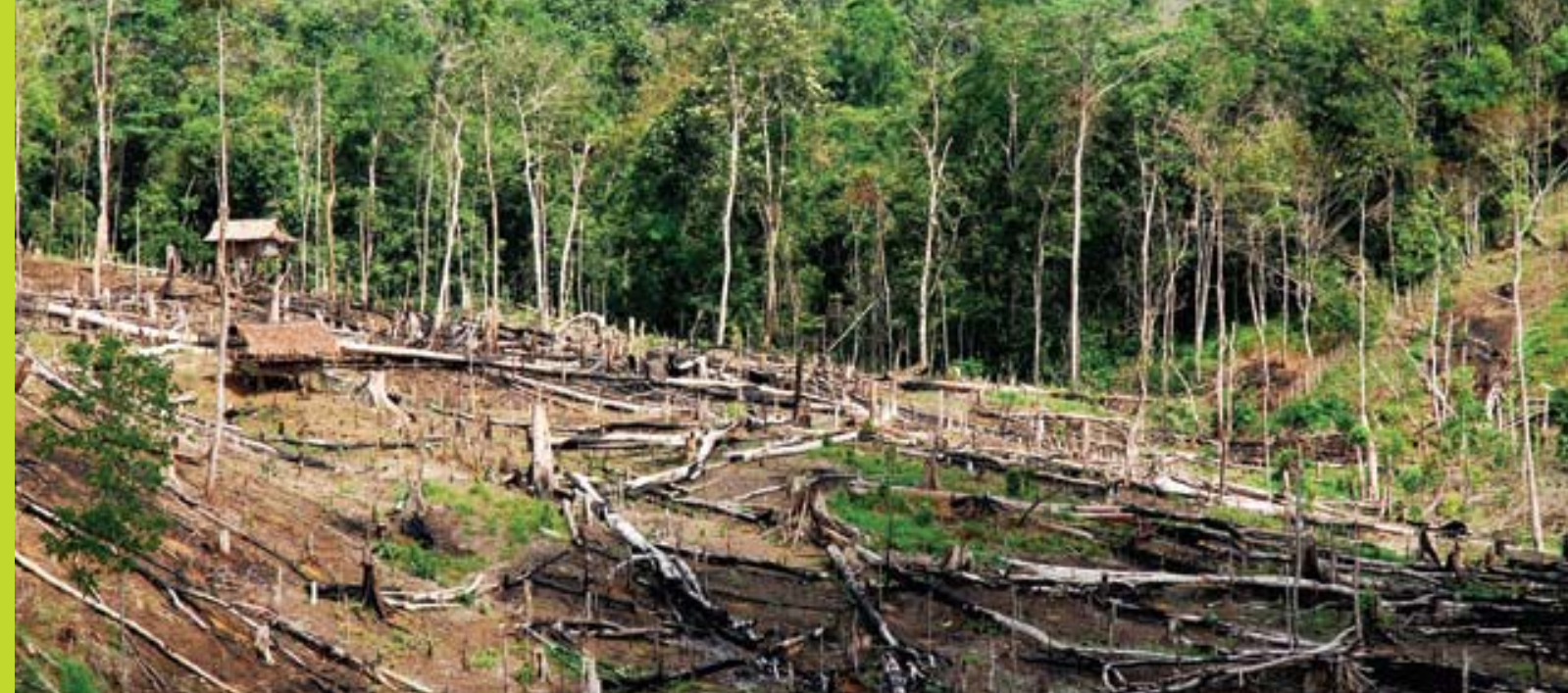

\section{Chapter' 7}

\section{How do we deal with leakage?}

Sven Wunder

\subsection{Introduction}

Imagine you live on a mountain lakeside. Recently, glacier melting from global warming has repeatedly caused severe flooding of your lands. You therefore decide to build a dike to protect the lowest-lying, most flood-prone lands. But since the lake is small, doing so will further raise the lake's water level and lead to flooding of previously unaffected areas. If your overall objective was to protect lakeside land from flooding, the projected gains from the dike project need 'leakage' deduction, i.e. quantification of losses from shifting some flooding pressures elsewhere in space.

In principle, carbon leakage is a similar off-site effect. While the 37 developed countries in Kyoto Protocol's Annex I countries have agreed to cap their industrial emissions, increasing imports from non Annex I countries may cause emission 'leaks'. Greenhouse gas (GHG) net emission reductions in one area are affected by project-attributable emissions outside of targeted mitigation areas. Leakage can occur whenever the spatial scale of intervention is inferior to the full scale of the targeted problem. Carbon mitigation is a global goal, so leakage can occur at various scales-farm-level, local/regional, 
national, or international/global - and in many sectors, including energy and forestry mitigation projects. Carbon leakage is fundamentally an economic process, although other anthropic and biophysical processes may interfere. Unlike in the dike example of exclusively 'crowding out' pressures, mitigation leakage may sometimes work in the opposite direction as well, i.e. a mitigation activity may be 'crowding in' further emission reductions from areas outside the defined mitigation area (called 'reversed leakage').

Taking a reducing emissions from deforestation and degradation (REDD) example, a farm-level payment for environmental services (PES) programme may reward the landowner for not deforesting the PES-enrolled forest plot A during five years. However, if the owner shifted all planned deforestation from plot $A$ to another, non PES-enrolled plot B, mitigation would be entirely offset by leakage or 'displacement of emissions', as the phenomenon is called in the Bali Action Plan (Thirteenth Session of the Conference of the Parties - COP 13). If the landowner further used all PES funds to buy chainsaws to enable additional clearing and cattle to graze on the land, medium-run leakage may well exceed 100 percent of mitigation - implying leakage also has a time dimension, depending on how quickly economic and biophysical processes work. Conversely, if the landowner invested the money in ecotourism or agroforestry and stopped all clearing, leakage would be reversed, crowding in off-site mitigation gains beyond target plot A.

\subsection{Dimensions of leakage}

\subsubsection{Leakage channels}

Some analysts distinguish between primary ('activity-shifting') leakage caused by REDD stakeholders and secondary ('market' or 'partial/general equilibrium') leakage from third actors, e.g. in response to price changes (Aukland et al. 2003). Table 7.1 outlines broad differences in expected leakage across three mitigation project types. For REDD activities (last two columns), conservation set-asides are distinguished from sustainable forest management (SFM) projects.

Shifts in demand for land, whether through competitive land markets or other spatial substitution mechanisms, are the dominating leakage force for REDD (both conservation and SFM): since deforestation is primarily caused by land conversion to agriculture, closing the agricultural frontier will create land shortages, unless technologies allow for intensification, e.g. shortening fallows or intensifying pastures. Induced land shortages are more pronounced for REDD than for afforestation and reforestation (A/R), which is often carried out on degraded lands with low economic valuke. 
Table 7.1. Likely leakage impacts of forestry mitigation actions and transmission forces

\begin{tabular}{|c|c|c|c|}
\hline Project types & Afforestation and & REDD - Set-aside & REDD - Sustainable \\
\hline Leakage channels & Reforestation & Conservation & Forest Management \\
\hline A. Land markets & $\begin{array}{l}\text { Substituting crops/ } \\
\text { livestock through } \\
\text { plantations }\end{array}$ & $\begin{array}{l}\text { Curbing planned } \\
\text { agricultural land } \\
\text { conversion }\end{array}$ & $\begin{array}{l}\text { Curbing planned } \\
\text { agricultural land } \\
\text { conversion }\end{array}$ \\
\hline B. Labour markets & $\begin{array}{l}\text { Labour-using } \\
\text { initially; variable } \\
\text { later }\end{array}$ & $\begin{array}{l}\text { Less employment } \\
\text { may cause out- } \\
\text { migration }\end{array}$ & $\begin{array}{l}\text { Labour-saving, or } \\
\text { Labour-using shift? }\end{array}$ \\
\hline C. Capital markets & $\begin{array}{l}\text { Returns may attract } \\
\text { capital }\end{array}$ & $\begin{array}{l}\text { Crowding out } \\
\text { effects from lower } \\
\text { returns }\end{array}$ & $\begin{array}{l}\text { Impact on returns } \\
\text { disputed }\end{array}$ \\
\hline $\begin{array}{l}\text { D. Technological } \\
\text { innovation }\end{array}$ & Variable & $\begin{array}{l}\text { None (unless } \\
\text { combined with } \\
\text { ecotourism, } \\
\text { non-timber forest } \\
\text { products) }\end{array}$ & $\begin{array}{l}\text { Reduced impact } \\
\text { logging, etc. }\end{array}$ \\
\hline E. Output markets & $\begin{array}{l}\text { Planted forest } \\
\text { products (medium } \\
\text { run) reduce } \\
\text { extraction pressures }\end{array}$ & $\begin{array}{l}\text { No agricultural or } \\
\text { timber supply from } \\
\text { set-asides }\end{array}$ & $\begin{array}{l}\text { Less timber (short to } \\
\text { medium run) }\end{array}$ \\
\hline $\begin{array}{l}\text { F. Income } \\
\text { generation }\end{array}$ & Variable & Variable & Variable \\
\hline $\begin{array}{l}\text { G. Ecological } \\
\text { conditions }\end{array}$ & $\begin{array}{l}\text { Plantations increase } \\
\text { or decrease } \\
\text { ecological integrity } \\
\text { (pests, wind, } \\
\text { biodiversity, etc.) }\end{array}$ & $\begin{array}{l}\text { Increase in } \\
\text { landscape integrity } \\
\text { and adaptation, } \\
\text { avoided 'edge } \\
\text { effects' }\end{array}$ & $\begin{array}{l}\text { Increase in landscape } \\
\text { integrity and } \\
\text { adaptation, avoided } \\
\text { 'edge effects' }\end{array}$ \\
\hline
\end{tabular}

Note: Light grey cells indicate leakage (extra-site decrease in net mitigation effect), dark grey cells indicate reversed leakage (extra-site increase in net mitigation effect), and plain cells indicate ambiguous/context-dependent impacts.

REDD conservation tends to be less labour-intensive per hectare than most converted land uses, which may lead to out-migration and possibly relocated GHG pressures; for A/R and SFM projects, employment impacts are time and context-specific. Capital markets are among the most fungible forces: like in the dike example where water flows smoothly into the remotest corners, financial capital normally flows smoothly towards high-return options. Capital may thus respond to all mitigation-induced constraints that lower returns by financing higher-return options elsewhere. SFM and A/R may sometimes offer attractive investment opportunities, thus 'crowding in' capital and causing reversed leakage.

Technological innovations in SFM (e.g. reduced-impact logging) may reduce forest degradation in neighbouring areas, but technological spread is usually negligible for conservation and $A / R$. For output markets, $A / R$ will increase future timber supply (though likely reduce crop and livestock output). 
In contrast, REDD conservation will reduce both (short-run) timber and agricultural supplies, raise commodity prices, and thus possibly stimulate production elsewhere. Note that reduced deforestation may induce higher forest degradation elsewhere through timber markets. SFM also curbs crop and livestock expansion, but sustains timber supply over time.

Income effects, backwards and forwards production linkages, and other changed development trajectories from mitigation projects are complex and difficult to determine a priori. But they can greatly influence leakage, and should thus be on the checklist. Finally, REDD may help keep landscapes ecologically healthy, including being more adaptable to climate change, avoiding 'edge effects' of forest degradation, and consequently reducing offsite GHG emissions. This reversed leakage under REDD is likely to be more important than for $A / R$ projects, which are dominated by monocultures.

\subsubsection{Size and importance}

Table 7.1 indicated that leakage forces (shaded cells) could potentially be more significant for REDD than for A/R, principally because REDD unambiguously tends to curb local land-based development. SFM probably causes less leakage pressures than set-aside conservation, but its disappointing adoption tropicswide indicates that it is also harder to implement. Does REDD generally leak more than energy and A/R projects? Energy-project leakage had in the Intergovernmental Panel on Climate Change (IPCC) $2^{\text {nd }}$ Assessment Report been estimated at a wide $0-70 \%$ range, but was later reduced to $5-20 \%$. There is little reason to believe that $\mathrm{A} / \mathrm{R}$ projects should have higher leakage (Chomitz 2000). Recent case studies confirm this view, e.g. slight reversed leakage found in the 10-year-old Scolel Té community tree-planting project in Chiapas, Mexico (de Jong et al. 2007). Sathaye and Andrasko (2007: 966) conclude that '[a]voided deforestation has a much wider range of leakage in analyses up to date $(0-92 \%)$, and appears to increase as the region of analyses is expanded'. Wu (2000) finds leakage effects in the U.S. Conservation Reserve Program's land-retirement programme around 20\%. Only one REDD project in the tropics has been analysed thoroughly: the Noel Kempff project in Bolivia (Box 7.1). The difficulties of setting REDD baselines, with two orders of magnitude of variation between three alternative model projections, illustrate the largest current problem: few real-life REDD projects and tentative quantification models leave enormous space for speculation. We thus do not really know how large REDD leakage is, let alone how it compares with other sectors (Schwarze et al. 2002). 


\section{Box 7.1. The Noel Kempff project: Carbon mitigation by curbing logging and deforestation}

In 1997, three electricity companies interested in the voluntary carbon market joined forces with The Nature Conservancy and invested USD 9.5 million in the 634,000 ha extension of the Noel Kempff National Park in eastern Bolivia. The money was used mainly to buy out timber concessions and large landowners, and to initiate integrated conservation and development projects (ICDPs) with three local communities. Focus was initially on avoided logging (forest degradation), but shifted over time towards avoided conversion to agricultural uses (deforestation). Primary leakage prevention was key in the contractual design, preventing in particular logging concessionaires from simply setting up shop elsewhere in Bolivia. Leakage for the stop-logging component was thoroughly screened and found to be in the $2-42 \%$ range, wood decomposition rates and timber-demand elasticities being most influential. Deforestation among local communities actually increased initially, which was hoped to be transitory, related to the creation of new land use systems. Setting baselines for deforestation and logging proved to be tricky. Three models for baseline carbon emissions over 20 years reached dramatically variable results: $\mathrm{FAC}=11.54 \mathrm{TgC}, \mathrm{GEOMOD}=1.05 \mathrm{TgC}$, and $\mathrm{LUCS}=0.18 \mathrm{TgC}$. For timber leakage, a dynamic optimisation model was constructed. For the spatial modelling of deforestation leakage, GEOMOD would be most appropriate, but short-run projectinternal deforestation had not been cut, and remoteness seemingly still limits dangers of increased land colonisation by squatters in buffer zones.

Sources: Winrock (2002), Sohngen and Brown (2004), Brown et al. (2007)

\subsubsection{Determinants of leakage}

Few REDD schemes are currently in operation, so asking for credible leakage estimates or leakage-proof design recipes is premature. It is helpful to play around with the numbers, but prediction ranges remain unacceptably wide.

Domestic leakage may significantly affect subnational REDD schemes. If a nation loses $1 \%$ of its forest cover annually, 99\% is not currently threatened. Advocates of REDD's cost efficiency, e.g. the Stern Report, assume this 1\% can be exactly identified, an obviously unrealistic position. Indeed, deforestation in forwards-moving agricultural frontiers is highly concentrated, e.g. in the Brazilian Arc of Deforestation. Spatial modelling in Mexico now allows prediction of two thirds of deforestation, using variables such as closeness to roads and markets, soil quality, slopes, population growth, etc. Yet, in areas where gradual clearing of forest islands in agricultural landscapes prevails, spatial prediction of deforestation is much more challenging, and addressing leakage will be more complex. Hence, errors in spatial prediction, and higher spatial fungibility of economic pressures, imply that additional reserves beyond the initially threatened ones will have to be simultaneously protected. Such multisite leakage threats may increase REDD costs significantly. 
Some common-sense leakage pre-assessment for different sites and scenarios may, however, help (see Figure 7.1). First, if labour and capital are highly mobile, then REDD-displaced activities and emissions will easily flow elsewhere (a). If adjacent forest areas with suitable soil conditions and weak protection status or low land price are available, then leakage into those areas is more likely than if the alternatives are remote, well-protected, expensive, and/or less apt for conversion (b). If demand for REDD-constrained products (timber, crops, livestock, etc.) is price-inelastic, i.e. the REDD-induced reduction in supply will not result in much reduced demand, then the activity is more likely to leak (c). Flexible production technologies can help absorb land scarcity from REDD set-asides at the local level (d), e.g. when land-extensive Amazon cattle ranching is intensified through pasture renovation or when slash-and-burn cycles are reduced through improved fertilisation. Conversely, if mechanised soy production depends on a technology package with fixed input coefficients, land-saving local adaptations are precluded and leakage becomes more likely.

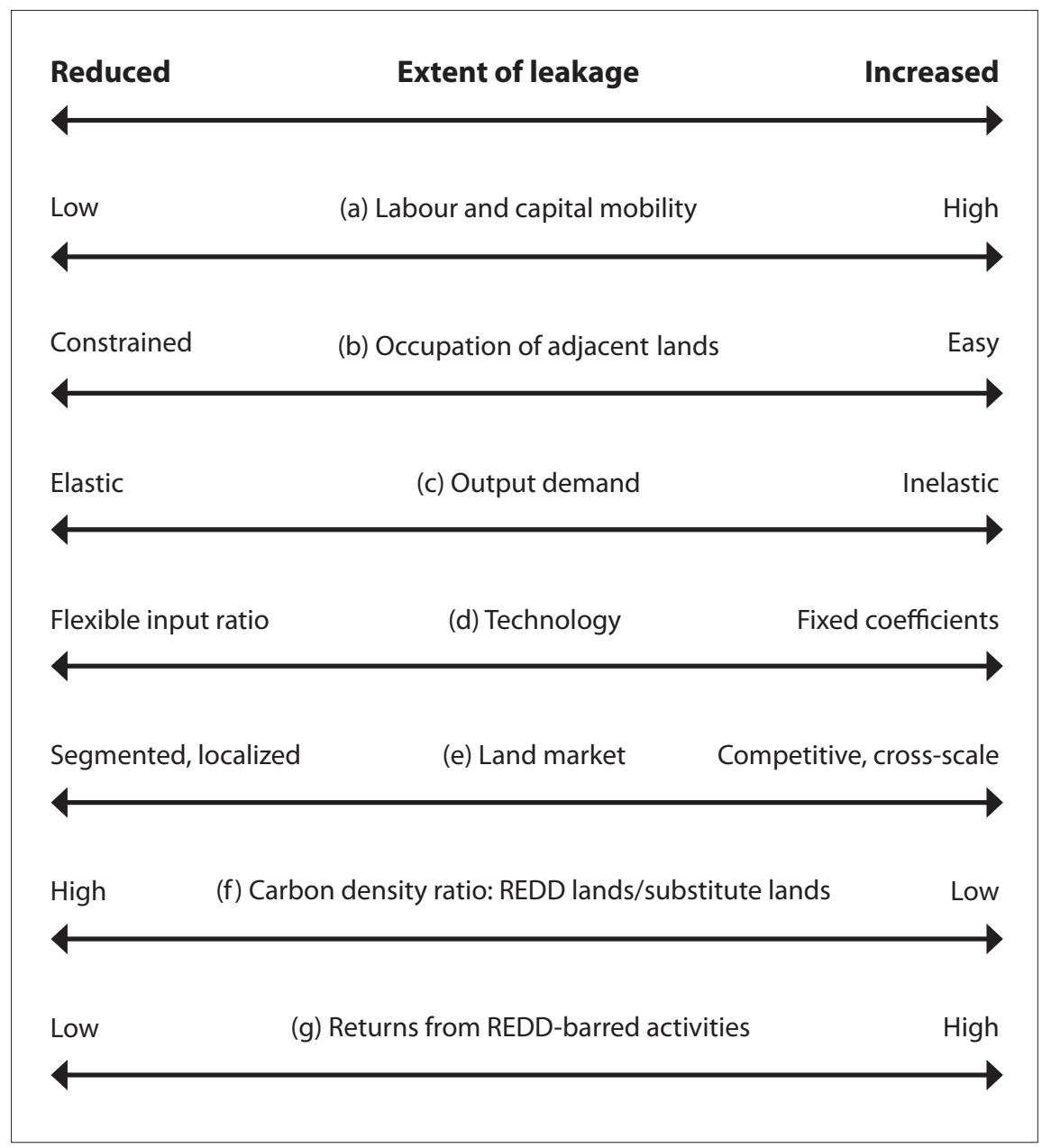

Figure 7.1. Main likely explanatory factors behind high vs. low leakage scenarios 
If land markets are competitive and integrated across regions and scales, then leakage is more probable (e). For instance, when in the 1980s Brazilian soy farmers expanded, they bought out small farms in the drier parts of central Brazil, pushing cattle production farther north, including into the Amazon. Conversely, in Papua New Guinea practically all land is owned by local communities, and large-scale market-led land reallocations of the Brazilian type would be unlikely.

Leakage is also about how much carbon is stocked on the protected land, compared with the land REDD-restricted activities move to - including changes over time in comparative carbon stocks (f). High-value activities, such as oil palm, soybeans, perennials, logging, or mining will - if effectively barred by REDD - more easily overcome the incremental transport and relocation costs of moving elsewhere than low-value production such as firewood, slash-andburn agriculture or land-extensive pastures (g). Pre-checking of considerations (a)-(g) may put in question some carbon-mitigation proposals from the outset, as in the Ecuadorian Yasuní case (Box 7.2): even without any measurement efforts, leakage problems appear overwhelming.

\section{Box 7.2. The Yasuní proposal: Carbon mitigation by keeping oil underground}

Yasuní National Park in Ecuador's Amazon region has forests with extraordinary biodiversity, but also large oil reserves. President Correa announced in June 2007 the intention to extract oil from the 982,000 ha park unless the international community came up with annual compensations of USD 350 million over 20 years, representing about half the estimated oil revenues. Notwithstanding biodiversity-conservation gains, carbon benefits alone are argued to more than justify such payments: 111 million tons of carbon otherwise exported would be kept underground and forest-degradation emissions from drilling and transport infrastructure avoided. Permanence after 20 years, and the moral hazard of threats to abolish a longestablished park, may render the proposal controversial. Yet, selected criteria from Figure 7.1 also reveal that, while the proposal's REDD component may work, the leakage from keeping the oil underground would likely approach $100 \%$ : global energy demand is highly inelastic, while energy supply is elastic. Thus, barring Yasuní oil extraction would - through marginal price changes - move most oil production elsewhere (c). Little labour is required, oil-industry financial capital is highly mobile (a), and returns from extraction are very high (g), thus further facilitating spatial factor fungibility and high global leakage.

Source: Correa and Moreno (2002) 
Wood harvesting activities (driving forest degradation) and agricultural conversion (driving deforestation) are sometimes lumped together in REDD leakage overviews (Murray 2008), yet represent substantially divergent economic processes. Logging of high-value species is typically a rent-seeking activity requiring little spatially fixed investment; deforestation is normally an immobile investment in future land uses, has more variable returns, and is on average less export-orientated. According to Figure 7.1, high-value logging would normally have higher leakage than deforestation.

Finally, different leakage scales are important for different purposes. Onfarm leakage is key for PES scheme design, a vital on-the-ground REDD implementation tool. Project-level leakage is important for investors, though regional-level baselines are often more reliable (Sathaye and Andrasko 2007). Nested REDD approaches can help be a bridge to national-level goals (Chapter 9). International REDD leakage into high-forest-cover, low-deforestation countries (e.g. Gabon, Suriname) may occur if these countries do not receive moderate preventive incentives to protect their large forest stocks (da Fonseca et al. 2007), linking leakage to both crediting baseline and stock-flow issues (Chapters 6 and 9).

\subsection{Options for dealing with leakage}

\subsubsection{Monitor}

Leakage is doubtlessly a key 'REDD flag'. Given its complexity, an overarching recommendation in many United Nations Framework Convention on Climate Change (UNFCCC) submissions (e.g. Colombia, European Union, United States of America - see Appendix) is to better monitor its extent. For primary leakage, historical deforestation figures (preferably sectorally disaggregated) are vital. Careful selection of control areas can help monitoring impacts within and outside project boundaries. Local socioeconomic surveys and trend indicators (demographics, prices for land, crops, livestock, and timber) can provide further understanding and measurement of offsite project impacts (Aukland et al. 2003). The Voluntary Carbon Standard for land use projects and the BioCarbon Fund now recommend leakage-belt monitoring, e.g. areas five to seven times the size of project areas greater than 100,000 ha and 20 to 40 times the size of smaller ones $(<100,000 \mathrm{ha})$. Secondary and internationallevel leakages need monitoring through better economy-wide or global trade models using improved data, thus hopefully reducing the currently huge predictive ranges and modelling sensitivities (section 7.2). 


\subsubsection{Increase scale}

Many UNFCCC submissions recommend higher accounting and crediting scales, i.e., moving from subnational to national levels, as the key to leakage control (see Chapter 4). International leakage through commodity markets is potentially high for REDD actions that significantly curb global commodity supply, as rising world market prices stimulate production elsewhere. Thus, the more deforesting countries participate in REDD, the less international deforestation leakage is likely to occur.

\subsubsection{Discount}

Some UNFCCC submissions (e.g. Colombia, World Bank - see Appendix) express doubts over how much increasing the REDD-scale will help leakage control in practice. As long as country participation remains below certain thresholds, one may need to discount REDD benefits not only for nonpermanence, but also for their estimated international leakage (Murray 2008). The various UNFCCC-proposed mechanisms, such as banking non-credited conservation reserves, insurances, discounted credits, or leakage-adjusted baselines and targets (Murray 2008), essentially have similar purposes of more conservative credit accounting. Improved monitoring is required to know just how large discount factors should be. This can also be a useful focus for learning in REDD demonstration projects.

\subsubsection{Redesign}

Less often featured in UNFCCC submissions, yet equally important are national and project-level design questions (section 7.2.3): how large are leakage risks for different on-the-ground REDD actions? Do focus, location, boundaries, and incentives of the proposed action make sense in a leakage control perspective? Given quite different effects originating from REDD conservation, SFM, and A/R projects (Table 7.1), can careful national/regional balances among them help control leakage by better absorbing crowded-out labour and capital (Schwarze et al. 2002)? Getting these balances right may substantially reduce subnational leakage.

\subsubsection{Neutralise}

Some 'decision-tree' stylisations (Aukland 2003:129) recommend addressing all primary leakage through neutralising 'alternative livelihoods' components. However, as we know from decades of Integrated Conservation and Development Project (ICDP) investments, shifting people into alternative livelihoods can be a daunting challenge. If the productive shift, for instance, requires Brazilian cattle ranchers to adopt more land-intensive pasture 
management, then adding a targeted intensification training and incentive package may be advisable. If it entails turning logging workers and shifting cultivators into ecotourism operators and non-timber forest entrepreneurs - as in the Noel Kempff case - the task may become overly difficult, costly, and risky. Conversely, some ICDPs become economically over-successful, creating 'magnet effects' that attract migrants and increase natural-resource pressures (Wittemyer et al. 2008). Some land-intensifying, high-yield technology diffusion, often recommended by leakage experts, can ultimately be adopted so widely that deforestation increases, causing so-called 'super-acceptance effects' (Aukland 2003).

\subsection{Assessment of options}

If you strike your fist into a down pillow, you will compress some feathers, but others will inevitably bulge at other ends. Similarly, REDD leakage is impossible to eliminate completely unless all global forests and woodlands were to be REDD-enrolled simultaneously. But given its importance, how can leakage be addressed in ways that balance effectiveness, efficiency, and equity?

Doubtlessly the most effective way is to increase REDD scales, both within and among countries. Under current climate policy, international leakage in particular is the rule, independent of the mitigation sector. Only broadened global participation can reduce it, and here REDD constitutes a strategic entry point. If leakage is safely quantifiable through monitoring (7.3.1), it is advisable to discount benefits or bank 'reserve credits' (7.3.3), ensuring that only net emission reductions are rewarded. Redesigning REDD interventions can effectively restrict in-country leakage (7.3.4). Leakage neutralisation (7.3.5) is only exceptionally recommendable; add-on ICDP projects risk becoming 'REDD and white elephants'.

As to cost efficiency, there is probably an optimal monitoring level, beyond which measurement of particularly degradation leakage makes little sense. However, explicit monitoring boundaries have to be defined. Attempts at leakage neutralisation may often be more expensive than redesigning the scheme or discounting the credits. In spite of the complexities at hand, efficient and cost-effective leakage control seems an attainable goal; leakage risks should not lead us to abandon REDD.

In terms of equity and development concerns, leakage may actually indicate a healthy economy: in response to REDD-induced barriers, production factors float fluidly to new opportunities, keeping welfare losses minimal. For instance, if a REDD set-aside impedes forest conversion for high-return soybean production, preventing this conversion from leaking may not be socially desirable if high foreign-exchange and multiplier benefits are foregone. 
Even explicit primary leakage contracts, e.g. the deals in Bolivia impeding loggers from moving elsewhere, may be undesirable from a welfare perspective. Additionally, in a world of mobile financial capital, they may ultimately have only short-run effects. Redesigning REDD towards factors that are less mobile and leakage-producing (e.g. labour, marginal lands) may also improve equity by creating pro-poor REDD investments. Balancing activity-reducing REDD conservation with activity-expanding $A / R$ and SFM interventions in the mitigation portfolio may impede impoverishing labour expulsion. Recognising trade-offs between carbon mitigation and broader development goals may thus lead us to deliberately accept some leakage and to reprioritise mitigation actions. 



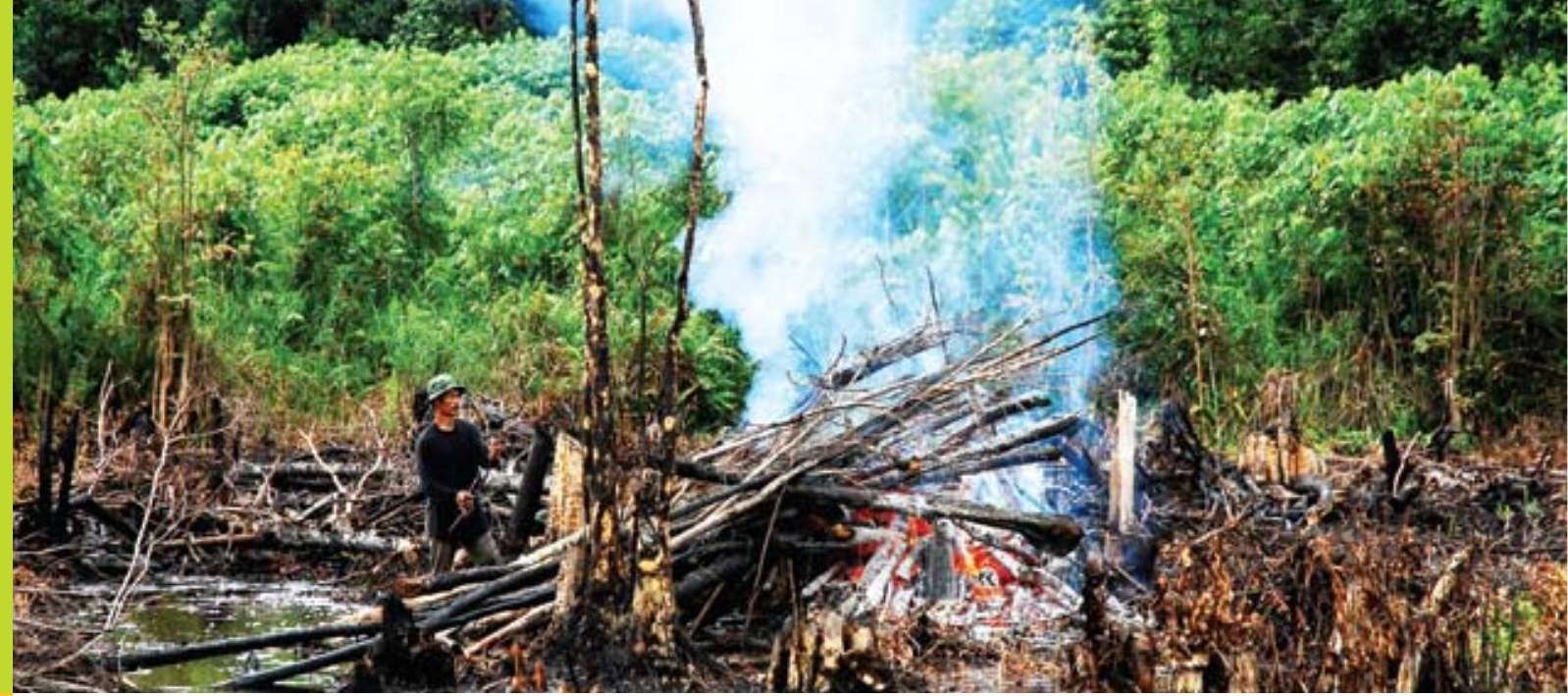

\section{Chapter 8}

\section{How do we ensure permanence and assign liability?}

Michael Dutschke with Arild Angelsen

\subsection{Introduction}

One of the major concerns in the reducing emissions from deforestation and forest degradation (REDD) debate is the permanence of emissions reductions. How can we make sure that a forest area saved today will not be destroyed tomorrow? Who should be held liable if that happened? How can REDD contracts and financial mechanisms be designed to ensure permanence?

Compared with other climate change mitigation options, forestry is often considered special in two ways. First, it is more difficult to control the carbon storage. Even under the best management practices, an unexpected carbon release cannot be excluded. Droughts, pest, or fire have the potential to revert yearlong carbon uptake within weeks or months (Schlamadinger $e t$ al. 2007). Second, the climate effect of a forest mitigation activity is linked to the continued existence of trees on the area once verified. An effective REDD mechanism must provide continuous incentives for landowners to monitor and maintain their forestlands. 
There are at least three counter-arguments against a categorical distinction between reduction of fossil emissions and carbon management in terrestrial systems: First, given the finiteness of fossil fuels, it is likely that they will anyway end up in the atmosphere over the long run. Reduced fossil fuel use today preserves a part of the reservoirs of coal, oil and gas, and carries the risk of higher production and consumption of the share in preserved today in the future. The question of permanence is therefore not limited to REDD.

Second, even if terrestrial carbon sequestration was in fact temporary, it will still have a positive climate effect (see the 'ton-year approach' discussed below). Related to that, REDD can produce large emissions reduction quickly, buying time for technological development and be a 'wooden bridge to a clean energy future' (Lecocq and Chomitz 2001). Without mitigation from forestry, the world is unlikely to get the quick emissions reductions needed to reach the maximum 2 degree Celsius target (e.g. Stern 2007).

Third, in most of today's developed countries, deforestation was a phase of development. Forest transitions tend to occur in phases: from slow to rapid deforestation to a phase of stabilisation and a later transition to a slow increase in forest cover (Rudel et al. 2005). Successful REDD will preserve forests during this risky development phase, and much of it will turn out to be permanent (Chomitz et al. 2006).

Still and although not uniquely confined to REDD, permanence is a real issue that will have to be taken into account in the REDD negotiations. Once someone assumes liability for terrestrial carbon stocks, non-permanence may still be a threat, but its damaging effects to the atmosphere are being compensated for. This may be the case in the future, if developing countries assume proper emissions targets, for example, within a cap and trade (CAT) system (Eliasch 2008). Before this happens, we need to find intermediate solutions. This chapter looks at different permanence risks and how these can be managed, and provides a toolbox of different liability mechanisms needed for achieving fungibility of carbon credits from land use and other sectors.

\subsection{Permanence risks and how to manage them}

There are a number of direct risks that can jeopardise the permanence of the emissions reductions achieved. One layer of risk management is how the risk of re-emission can be managed by projects or countries. A second risk management layer is needed, however, if REDD mechanisms are to be credited and used for compliance in voluntary or formal (compliance or offset) greenhouse gas (GHG) markets. In this case, some system of commercial liability must be 
in place. Both layers are necessarily overlapping. The main distinction is that permanence risks need to be managed anyway, independently from whether emissions reduction credits are being generated, while the second layer is a commercial necessity in case REDD credits are to be traded.

\subsubsection{Risks and risk management}

What are the risks that can jeopardise the permanence of carbon stored in forests? We distinguish between the following types of risk (Wong and Dutschke 2003):

1. Natural/ecological risk: Erratic variations in carbon stocks, caused by natural events such as storm, drought, pests, or fire.

2. Climate change-related risk: Climate change may lead to systematic carbon losses in certain regions. This is distinct from other types of natural/ ecological risks in that it involves a new class of threats that may be more difficult to insure, as historical experience is lacking.

3. Demand-side risk: Where the demand for agricultural crops is the main driver of deforestation, an increase in prices on the national or world market may drive up opportunity costs to levels above the carbon prices agreed, making forest conversion profitable.

4. Failure of project partners: Risk related to non-performance of the project can be due to, for example, ineffective project management, insecure tenure rights to the forest (encroachment), or bankruptcy of project partners.

5. Political risk: A change in government may lead to a change in or reversal of any prior approvals or commitments. The same may occur in the event of civil unrest. Depending on how the REDD mechanism will be ultimately designed a change in status from non-Annex I to Annex I country may also impact subnational activities.

In case of natural events (risk type 1), traditional forest insurance covers the difference between the salvage value of timber and the commercial value of the trees at maturity. Contracts are usually renewed on an annual basis, in order to reflect the actual risk profile. This coverage can be expanded to the carbon fixed in vegetation. This expansion would require insurance companies to participate in the emissions market.

Long-term climate variations (type 2) will not uniformly lead to worldwide damages, but they can negatively impact large areas, while climate change may lead to increased biomass growth in other areas. In case indirect human interference can be factored out, these risks (and benefits) will not be attributed to the individual activities. 
The risk for a change in commodity prices (3) can be shared between funding agency and landowner by including an indexing clause in the contract that foresees additional payments during times when the prices of, say, soy or palm oil move outside a predetermined price corridor.

In case the project owners fail to meet the obligations or disappear (4) and permanent credits have been created, the ultimate liability will fall back to the government, most likely the one of the selling country. In order to be able to respond to this risk, the national REDD focal point may ask for an in-kind risk premium (e.g. a credit sharing clause), before approving a subnational activity.

Political risks (5) can be minimised by broad participation in the climate regime and by international cooperation. Nevertheless, under an international agreement like the United Nations Framework Convention on Climate Change (UNFCCC), the basic construct is that states are permanent and comply with treaties. Legal enforcement options against states are necessarily limited.

\subsubsection{Liability management}

Permanence risks apply independently from any credit trading under a future REDD regime. Under a national approach, the concern is no longer the permanence of particular forest areas, but whether the country as a whole continues to maintain reductions below the referencelevel established, regardless of where the particular reductions are coming from. A critical question then arises: What happens if the country exceeds its reference level? One option is the requirement that the nation makes up the reductions or pay some other penalty. Under a 'debit system', for example, any emissions above the reference level will be deducted from a future account (perhaps plus interest or some additional penalty). The extra emissions must then be made up before any later reductions below reference level are credited (Schlamadinger and Johns 2006).

However, before REDD countries accept full liability for reductions achieved or if REDD credits from subnational activities are to be made fungible with other mitigation credits or allowance units, the resulting commercial risks need to be securitised. The following options exist:

1. Temporary crediting conditions the validity of carbon credits from land use to the continued existence of the carbon stocks (Blanco and Forner 2000). This approach has been applied under the afforestation and reforestation (A/R) clean development mechanism (CDM). Depending on the modality, emissions reductions have to be either recertified or reverified after five years for the credit to remain valid. In the CDM, when the project lifetime (up to 60 years) ends or in case of premature losses, credits need to be replaced by other types of emissions allowances. Thus, under the current CDM rules, temporary crediting always creates a future debit, independently of the fate of the carbon stocks built up. 
2. The so-called 'ton-year approach' was discussed in the Intergovernmental Panel on Climate Change (IPCC) Special Report on Land Use, Land-Use Change and Forestry (Watson et al. 2000). It departed from the ideas that (i) the present value of mitigation is higher today than the same mitigation effect tomorrow, and that (ii) there is a limited residence time of $\mathrm{CO}_{2}$ in the atmosphere. The combination of human time preference and the natural decay period led various authors to the calculation of an 'equivalence period', after which forestry mitigation could be considered permanent. Authors proposed the length of this equivalence period to be between 42 and 100 years (Fearnside et al. 2000; Moura Costa and Wilson 2000; Fearnside 2002). Consequently, with an equivalence period of 100 years, keeping 100 tons of $\mathrm{CO}_{2}$ out of the atmosphere over 1 year would be equivalent to 1 ton of $\mathrm{CO}_{2}$ permanently removed. This type of accounting has a big drawback in the cash flow: full payment for permanent reduction accrues after the end of the equivalence period, while the costs are mainly frontloaded. Nevertheless, the private sector might separately be willing to advance upfront loans based on the credit worthiness of the project and the expected future stream of payments.

3. Project credit buffers are another option used in voluntary mitigation projects. Only a certain share (e.g. 50\%) of the credits generated are sold, while the remainder is held in an escrow account for a predetermined period (e.g. 50 years). A proportion of these credits are liberated as the guarantee period ends if no losses have occurred.

4. Risk pooling is a variation of project credit buffers where several projects maintain a joint credit buffer, thus minimising the risk of damages occurring simultaneously. The individual project buffers can be smaller than nonpooled project credit buffers. The same would be the case for a nationallevel REDD program in which risks are spread across activities and regions across the country.

5. Insurance is an advanced version of risk pooling. A third-party insurer selects a portfolio of insured projects in a way that several growth regions and ecosystems are covered, thereby limiting the risk of occurrence of massive simultaneous damages. The risk premium is paid in emission reduction units. In case of a damage event, the insurance company replaces credits lost by the ones held in stock. The residual risk is hedged by financial instruments and re-insurers (Subak 2003). This scheme can also lead to an improved cash flow for mitigation activities.

6. Shared liability or forest compliance partnership (FCP), is a proposal for managing national-level liability under a 'bubble' approach on land use accounting between two or more Annex I and non-Annex I countries (Dutschke and Wolf 2007). Under this construct, developed countries would bear a negotiated share of the liability for the permanence of REDD credits once they are certified. They could account for the landuse sector under their sectoral target, stipulated under Kyoto Article 3, paragraphs 3 and 4 or any new agreement agreed upon. The FCP suggests 
that a developed country receives preferential access to REDD credits for compliance if it shares the liability. The proposal assumes that for compliance with Annex I targets, certain restrictions apply with regard to the use of REDD credits. Aid donors would also become motivated to invest in forest governance. Bilateral funding will be directed into the most effective policies and measures to reduce emissions in the forestry sector. The special relationship between REDD countries and their Annex I stewards will have repercussions on the private sector too, because FCP limits the country risk for subnational activities with foreign participation.

Several combinations of the above options are possible. For example, options 1 and 2 can be combined with a sliding cancellation of debits incurred from temporary crediting over time (Dutschke 2002), thus improving the cash flow for mitigation activities. Temporary forestry credits have to be replaced in the future, but each year until the equivalence period a prorated percentage of this future debit is forgiven, in case no damage occurs.

All except option 1 limit the liability over a predetermined timeframe. The ton/year approach considers forestry mitigation effects permanent after the equivalence period. Credit buffers and insurances release credits from the escrow account, as no damages occur for a certain number of years. For A/R CDM projects in the first commitment period, no temporal horizon of the risks for sequestered carbon could be agreed upon. Therefore temporary crediting was chosen that assumes all mitigation to be lost after project termination. Nevertheless, this assumption has stifled the market's appetite for temporary and long-term certified emission reduction. As the price of temporary credits point to the future value of replacement units, these credits are highly speculative and lose their value if more stringent targets are expected for subsequent commitment periods. With stable market signals in place and banking of credits being allowed, this situation may change in future commitment periods.

With the 2 degree Celsius target to be reached until the middle of this century, the timeframe for mitigation action is much clearer now than it was when rules and modalities were discussed for A/R CDM. Thus, all the options dismissed at that time can come back into consideration for REDD liability management. 


\subsection{Evaluation of liability management}

Assigning liability is a precondition for credit fungibility. Independently from the mode of financing proposed under a REDD system options, the criterion of environmental effectiveness requires that the overall effect is a lasting reduction of GHG levels in the atmosphere. Table 8.1 lists options that have been proposed for safeguarding permanence of emissions reductions and carbon uptakes in terrestrial systems, and each of them is assessed in terms of the $3 \mathrm{E}$ criteria used in this book (effectiveness, efficiency and equity). Options 1 and 2 avoid a clear allocation of liability and consequently are suboptimal in terms of all three criteria. In the start-up phase of a nested approach (chapter 4), temporary crediting may be a useful fix, before national REDD targets are set and the ultimate country liability is determined. After that, credits may be converted from temporary to permanent. Once there is ultimate country liability, like in the case of Annex I parties, any re-emission is captured in the national inventory and is taken into account when meeting emissions reduction commitments.

The options listed are non-exclusive; they may be seen as a logical succession, once the activities reach a certain volume. In options 4 and 5, there may occur 'cherry-picking' of 'good risks' by pool operators. Annex I countries should consider providing international start-up finance to organise larger pools, make these accessible to countries perceived as 'high risk', or work with these countries to reduce their risk profile. Option 6 is only related to nationallevel REDD, and it is complementary to all other options. It offers potential investors and insurers higher confidence that ultimate liability for credits is backed by Annex I support, and thus political risks are minimised. It has the potential to increase the effectiveness of policies and measures in the landuse sector and bolster private investment in REDD. It is equitable in that it can contribute to the attractiveness of countries that would otherwise have difficulty attracting REDD investment because of their political risk.

Table 8.1. Options for securitising permanence in terrestrial carbon management

\begin{tabular}{lllll}
\hline & & Effectiveness & Efficiency & Equity \\
\hline 1 & Temporary & Low & Low & Low \\
crediting & $\begin{array}{l}\text { Start-up option for } \\
\text { small overall carbon }\end{array}$ & $\begin{array}{l}\text { Complex accounting } \\
\text { high transaction }\end{array}$ & $\begin{array}{l}\text { High transaction costs } \\
\text { benefit large projects }\end{array}$ \\
& $\begin{array}{l}\text { volumes and isolated } \\
\text { activities }\end{array}$ & $\begin{array}{l}\text { costs and low-value } \\
\text { credits result in } \\
\text { minimal use }\end{array}$ & \\
& & minal & \\
& & &
\end{tabular}


Table 8.1. (continued)

\begin{tabular}{|c|c|c|c|c|}
\hline & & Effectiveness & Efficiency & Equity \\
\hline 2 & $\begin{array}{l}\text { Ton-year } \\
\text { accounting }\end{array}$ & $\begin{array}{l}\text { LOW } \\
\text { Low upfront pay } \\
\text { and low net present } \\
\text { value (which } \\
\text { depends on discount } \\
\text { rate), limited } \\
\text { incentives }\end{array}$ & $\begin{array}{l}\text { LOW } \\
\text { Leads to heavy } \\
\text { discounts in credits, } \\
\text { which causes cash- } \\
\text { flow problems }\end{array}$ & $\begin{array}{l}\text { LOW } \\
\text { High financing costs } \\
\text { exclude poorer } \\
\text { participants }\end{array}$ \\
\hline 3 & $\begin{array}{l}\text { Project } \\
\text { credit } \\
\text { buffers }\end{array}$ & $\begin{array}{l}\text { MEDIUM } \\
\text { Effectiveness depends } \\
\text { on project credibility } \\
\text { and maintenance of } \\
\text { buffer }\end{array}$ & $\begin{array}{l}\text { LOW } \\
\text { High unaccounted } \\
\text { share of credits, late } \\
\text { cash-flow }\end{array}$ & $\begin{array}{l}\text { HIGH } \\
\text { Easy and transparent } \\
\text { implementation }\end{array}$ \\
\hline 4 & $\begin{array}{l}\text { Risk } \\
\text { pooling }\end{array}$ & $\begin{array}{l}\text { MEDIUM-HIGH } \\
\text { Effective instrument, } \\
\text { depending on pool's } \\
\text { size and distribution }\end{array}$ & $\begin{array}{l}\text { MEDIUM-HIGH } \\
\text { Smaller relative } \\
\text { buffer size }\end{array}$ & $\begin{array}{l}\text { MEDIUM } \\
\text { Organisational } \\
\text { capacities required, } \\
\text { risk of free-riding, but } \\
\text { fairly equitable }\end{array}$ \\
\hline 5 & $\begin{array}{l}\text { Commercial } \\
\text { insurance }\end{array}$ & $\begin{array}{l}\text { HIGH } \\
\text { Outsourced liability, } \\
\text { instrument for } \\
\text { mature markets, low } \\
\text { hurdles }\end{array}$ & $\begin{array}{l}\text { HIGH } \\
\text { Low transaction } \\
\text { costs through } \\
\text { outsourced risk } \\
\text { assessment and } \\
\text { management }\end{array}$ & $\begin{array}{l}\text { MEDIUM } \\
\text { May be equitable if } \\
\text { socially desirable 'bad } \\
\text { risks' are subsidised }\end{array}$ \\
\hline 6 & $\begin{array}{l}\text { Shared } \\
\text { liability }\end{array}$ & $\begin{array}{l}\text { HIGH } \\
\text { Will give additional } \\
\text { incentives to } \\
\text { readiness and } \\
\text { capacity building, } \\
\text { thus preparing the } \\
\text { ground for effective } \\
\text { REDD }\end{array}$ & $\begin{array}{l}\text { HIGH } \\
\text { Will make REDD } \\
\text { insurable, as country } \\
\text { risk is minimised }\end{array}$ & $\begin{array}{l}\text { HIGH } \\
\text { Depending on the } \\
\text { motivation of Annex I } \\
\text { parties involved, } \\
\text { may contribute to } \\
\text { fostering investment } \\
\text { in high-risk countries }\end{array}$ \\
\hline
\end{tabular}

\subsection{Conclusion}

Building up, managing and conserving carbon pools, whether in forests or elsewhere, entails the risk of non-permanence. This risk needs to be addressed for any climate change mitigation. Further, in order to make credits resulting from forestry mitigation fungible with other credits and emission allowances, liability mechanisms are needed. The risks for forest carbon stocks can be mitigated in a staggered approach, with different mechanisms covering different risk layers. The most efficient mechanism for risk pooling is national liability of REDD countries in case risk mitigation strategies should fail. As REDD governments do not (yet) have GHG targets for the whole economy, they are not in the position to cross-compensate underachievement in forestry 
with overcompliance in another sector. A shared sectoral liability ('emissions bubble') between developed and developing countries may thus add to the REDD system's stability. For the respective developed country partner, the benefit could be preferential access to the partner's REDD credits.

The chapter has offered a summary of tools proposed for reducing carbon risks in forestry and for securitising carbon contracts from forest mitigation activities. This toolbox is the result of pilot project development and a vivid methodological debate at the UNFCCC level over the last decade. Permanence and liability under a REDD mechanism can be realised by combining a variety of complementing approaches. The REDD decision expected in Copenhagen 2009 should offer a menu of choices based on what best serves different country circumstances. 

This chapter addresses the issue of MRV for reducing emissions from deforestation and degradation in developing countries (REDD) activities. We provide a summary of the state of the art and science of carbon MRV. Our aim is to show that many of the methodological concerns expressed in 2001 no longer constrain these types of projects. We believe that with the progress that has been made in the past seven years, a new policy environment that is more favourable to REDD projects will promote further innovation to increase the feasibility of projects that reduce a significant source of greenhouse gases to the atmosphere.

\subsection{Trade-off between costs and accuracy}

Different methods are available and suitable for monitoring deforestation, forest degradation and carbon stocks. Deforestation monitoring can rely on remote sensing technology with ground measurements for verification. Monitoring forest degradation and carbon stocks is more challenging, and largely relies on ground measurements, complemented by remote sensing.

Still, there is a trade-off between costs and accuracy of measurements. Measurement accuracy is crucial to ensure that emissions reductions are not over- or underestimated and payments for the reduction efforts are made appropriately. In some country contexts high accuracy levels require the use of fine-resolution imagery (e.g. to detect forest degradation or small-scale deforestation), imagery repeated over time (e.g. to overcome cloud cover limitations) or imagery that requires higher expertise to process (e.g. radar image analysis) - all of which come at a cost. Similarly, ground measurements, crucial for verification and carbon stock measurement, are time consuming and relatively expensive for large-scale applications such as a national-level inventory (Korhonen et al. 2006).

The cost vs. accuracy trade-off is all the more important as countries that need costly monitoring methods (due to clouds, hilly terrain or their drivers of deforestation or degradation) tend to correlate with those currently having low capacity to meet these needs. The recognition of this trade-off has led most parties to the UNFCCC to call for guidance from the international community on cost-effective methods to monitor, report and verify emission reductions from deforestation and forest degradation.

Official guidelines for REDD MRV are yet to be established. The 2003 Good Practice Guidelines for Land Use, Land-Use Change and Forestry (GPG-LULUCF) activities and 2006 Guidelines for National Greenhouse Gas Inventories for Agriculture, Forestry and Other Land Use (GL-AFOLU) - both developed by the IPCC - are important first steps, but need further elaboration on methods to estimate emissions from forestry, notably regarding 
sampling design and determining carbon densities in forests affected by degradation (UNFCCC 2008b). The adhoc REDD working group called the Global Observation of Forest and Land Cover Dynamics (GOFC-GOLD) undertook a first step to fill this vacuum. They are developing a sourcebook providing a consensus perspective from the global earth observation community and carbon experts on methodological issues relating to national-level REDD activities (GOFC-GOLD 2008).

\subsection{Elements of a measurement and monitoring system}

Due to the trade-off between costs and accuracy, the quest for cost-effective solutions is at the centre of the MRV debate. A cost-effective monitoring and evaluation system for REDD requires a balanced approach of remote sensing and ground measurements. The imagery aids in the design of efficient ground sampling schemes (e.g. in areas with high variability), assessment of area change (with ground truthing) and extrapolation of plot measurements to the regional or national level. Ground measurements are required for carbon measurements and to verify desktop forest mapping from satellite images.

Carbon emissions from deforestation and degradation are estimated from changes in two important variables: (i) area of deforestation and degradation; and (ii) carbon stock densities per unit area. Remote sensing technologies combined with ground measurements play a key role in monitoring these variables.

\subsubsection{Monitoring deforestation areas}

Remote sensing is the only practical method for national-level deforestation monitoring (DeFries et al. 2006). Since the early 1990s, changes in forest area have been monitored from space with confidence (Achard et al. 2008). Some countries (e.g. Brazil and India) have had well-established operational systems for over a decade; others are developing these capabilities or have successfully monitored forests with aerial photographs that do not require sophisticated data analysis or computer resources (DeFries et al. 2006).

The two most common approaches are wall-to-wall mapping and sampling. Wall-to-wall mapping, whereby the entire country or forest area is monitored, is a common approach and is conducted in both Brazil and India. Sampling approaches are useful to reduce the costs of data and analysis, and are especially suitable when deforestation is concentrated in discreet areas of a country or region. Recommended sampling approaches include systematic sampling, whereby samples are taken at regular intervals (e.g. every $10 \mathrm{~km}$ ), 
and stratified sampling, whereby samples are determined by known proxy variables (e.g. deforestation hotspots) (Achard et al. 2008). Expert knowledge can also help determine sample priorities (DeFries et al. 2006). A stratified sampling approach, used for example in the Brazilian Project to Monitor the Brazilian Amazonian Rainforest (Projeto Monitoramento da Floresta Amazônica Brasileira por Satélite - PRODES) identifies 'critical areas' based on the previous year's monitoring to prioritise analysis for the following year (INPE 2004).

One approach does not exclude the other: a sampling approach in one reporting period may be extended to wall-to-wall coverage in the subsequent period. Likewise, wall-to-wall mapping in one reporting period may be followed by hotspot analysis (stratified sampling) in the subsequent period.

One way to reduce costs is through a stepwise approach. In a first step, coarse resolution data (e.g. MODIS) is analysed to identify locations with high rates of land use change (deforestation hotspots). In a second step, more costly medium-fine resolution data (e.g. Landsat, SPOT, SAR) is used to conduct detailed analysis of these hotspots. This approach reduces the need to analyse the entire forested area within a country. Hansen et al. (2008) for example employed this methodology at global level to compute rates of humid tropical forest clearings between 2000 and 2005.

Reporting accuracy and verification of results are essential components of a monitoring system. Accuracies of $80-95 \%$ are achievable for monitoring with medium-resolution imagery (e.g. Landsat) to discriminate between forests and non-forests. Accuracy can be assessed through ground observations or analysis of fine resolution aircraft or satellite imaging. Aerial photography presents a good tool for verification as fine-resolution imagery remains expensive. Another source of free viewable data can be the fine-resolution imagery (up to $50 \mathrm{~cm}$ resolution) from Google Earth, which - where available - provides continuously updated data (Olander et al. 2008). ${ }^{1}$

\subsubsection{Monitoring forest degradation areas}

Forest degradation is caused by a variety of factors that affect monitoring requirements (Table 9.1; also see Chapter 10 on degradation). Repeated monitoring is needed to ensure all forest changes are accounted for and attributable to a particular time period. Requiring the use of remote sensing to stratify the land area in order to select the area for ground measurement has been proposed to overcome the challenges associated with the lack of a clear definition for forest degradation.

1 Although the imagery cannot be fully imported into image processing packages, it has great potential for map validation in some areas by combining visual interpretation with Geographic Information Systems polygon and point files that can be imported and overlain in Google Earth (Olander et al. 2008). 
Table 9.1. Causes of degradation and impact on monitoring

\begin{tabular}{|c|c|}
\hline $\begin{array}{l}\text { Causes of forest } \\
\text { degradation }\end{array}$ & Monitoring feasibility \\
\hline Selective logging & $\begin{array}{l}\text { - Remote sensing methods using medium resolution im- } \\
\text { agery can detect gaps in the forest canopy caused by roads } \\
\text { and log decks } \\
\text { - Reduction in carbon stocks can also be estimated with- } \\
\text { out satellite imagery using methods from the } 2006 \text { IPCC } \\
\text { GL-AFOLU, although it likely is more difficult to estimate } \\
\text { emissions from logging }\end{array}$ \\
\hline Forest fires & $\begin{array}{l}\text { More difficult to monitor with existing satellite imagery, } \\
\text { but possible to build on existing fire information for REDD } \\
\text { uses }\end{array}$ \\
\hline $\begin{array}{l}\text { Over-exploitation of } \\
\text { fuel wood and other } \\
\text { non-timber forest } \\
\text { products }\end{array}$ & $\begin{array}{l}\text { - Likely to be undetectable from satellite image interpreta- } \\
\text { tion unless the rate of degradation is intensive, causing } \\
\text { larger changes in the canopy } \\
\text { - Inventory-based approaches (field surveys) may be more } \\
\text { appropriate }\end{array}$ \\
\hline Mining & $\begin{array}{l}\text { - Difficult to monitor as forest openings are often too small } \\
\text { to be detected }\end{array}$ \\
\hline
\end{tabular}

Source: Adapted from GOFC-GOLD (2008)

Monitoring methods based on remote sensing may be appropriate when degradation leads to detectable gaps in the forest canopy such as is typically the case for selective logging or fire. Neverthless, ground measurements are important complements especially when degradation does not create gaps in the canopy such as in the case of collection of deadwood and understorey vegetation (Hardcastle et al. 2008).

Two main remote sensing approaches to monitor forest degradation are currently distinguished (Achard et al. 2008): a direct approach that detects gaps in forest canopies and an indirect approach that detects road networks and log decks.

- Direct approach to monitor selective logging and fire: Methods based on this approach monitor forest canopy for any gaps or pattern of gaps to identify degradation activity. ${ }^{2}$ For example, Asner et al. (2005) developed automated algorithms to identify logging activity using Landsat data. Roy et al. (2005) developed a methodology to map fire-affected areas using MODIS data. An accuracy of $86-95 \%$ has been shown to be achievable in the interpretation of selectively logged and burned areas (Achard et al. 2008).

2 See Achard et al. (2008) for a more detailed description of methods in this category. 
- Indirect approach to monitor forest degradation: This approach classifies forest land into 'intact forest' (fully stocked, undisturbed forest) and 'nonintact forest' (not fully stocked, disturbed forests due to timber exploitation or canopy degradation) based on a combination of canopy cover and human impact criteria that can be defined depending on national circumstances (Mollicone et al. 2007; Achard et al. 2008). ${ }^{3}$ Forest degradation is defined as conversion of intact to non-intact forest.

\subsubsection{Estimating forest carbon stocks}

Carbon stock estimates are necessary to determine net forest emissions, and are derived by combining the area extent of deforestation or forest degradation with carbon density measurements. Approaches to estimate forest carbon stocks in tropical countries can be grouped into biome averages, ground-based measurements and remote sensing measurements (Gibbs et al. 2007). Table 9.2 summarises the benefits and limitations for each method.

Converting forest inventory and remotely sensed data into carbon measures requires the development of allometric relationships. Several global relationships exist (e.g. Chave 2008), but it is better to develop country-specific equations. As most countries with high forest cover have forestry research services, and the generation of allometric equations is straightforward, they should be able to develop appropriate equations.

Using data from forest inventories is often tempting because many countries have already conducted at least one inventory. But few developing countries have comprehensive national inventories, and the data often refer to forests with commercial value only (DeFries et al. 2006).

\subsection{Estimating emissions from deforestation and forest degradation}

Combining measurements of changes in forest area with carbon density values enables estimation of net emissions from forest changes. The level of emissions released as a result of land use change depends not only on the forest type, but also on the specific type of change. For example, converting tropical forest to soybean, maize or rice potentially produces $60 \%$ more emissions than conversion to oil palm (Miles et al. 2008).

3 Achard et al. (2008) suggest that 'intact forest' be defined based on six criteria: 1) located in forestland according to current UNFCCC definition, with a $1 \mathrm{~km}$ buffer zone inside the forest area, 2) larger than 1000 ha with a smallest width of $1 \mathrm{~km}, 3$ ) containing a contiguous mosaic of natural ecosystems, 4) not fragmented by infrastructure, 5) without signs of significant human transformation, and 6) without burnt lands and young tree sites adjacent to infrastructure projects. 
Table 9.2. Benefits and limitations of available methods to estimate national-level forest carbon stocks

\begin{tabular}{|c|c|c|c|c|c|}
\hline \multicolumn{2}{|c|}{ Method } & Description & Benefits & Limitations & Uncertainty \\
\hline \multicolumn{2}{|c|}{ Biome averages } & $\begin{array}{l}\text { Estimates of average } \\
\text { forest carbon stocks } \\
\text { for broad forest } \\
\text { categories, based on } \\
\text { a variety of input data } \\
\text { sources }\end{array}$ & $\begin{array}{l}\text { - immediately available } \\
\text { - data refinements may } \\
\text { increase accuracy } \\
\text { - globally consistent }\end{array}$ & $\begin{array}{l}\text { - fairly generalised } \\
\text { - data sources } \\
\text { improperly sampled } \\
\text { to describe large } \\
\text { areas }\end{array}$ & High \\
\hline \multicolumn{2}{|c|}{ Forest inventories } & $\begin{array}{l}\text { Relates ground-based } \\
\text { measurements of tree } \\
\text { diameters or volume } \\
\text { to forest carbon stocks } \\
\text { using allometric } \\
\text { relationships }\end{array}$ & $\begin{array}{l}\text { generic relationships } \\
\text { readily available } \\
\text { - low-tech method } \\
\text { widely understood } \\
\text { can be relatively } \\
\text { inexpensive as field- } \\
\text { labour is largest cost }\end{array}$ & $\begin{array}{l}\text { generic } \\
\text { relationships not } \\
\text { appropriate for all } \\
\text { regions } \\
\text { - can be slow } \\
\text { - challenging to } \\
\text { produce globally } \\
\text { consistent results }\end{array}$ & Low \\
\hline \multirow{4}{*}{ 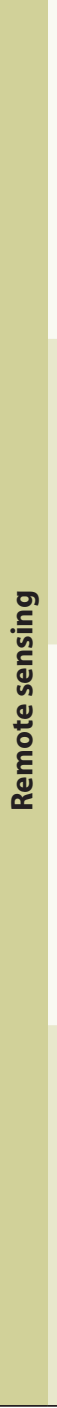 } & $\begin{array}{l}\text { Optical remote } \\
\text { sensors }\end{array}$ & $\begin{array}{l}\text { Uses visible and } \\
\text { infrared wavelengths } \\
\text { to measure spectral } \\
\text { indices and correlates } \\
\text { to ground-based forest } \\
\text { carbon measurements } \\
\text { (e.g. Landsat, MODIS) }\end{array}$ & $\begin{array}{l}\text { - satellite data routinely } \\
\text { collected and freely } \\
\text { available at global } \\
\text { scale } \\
\text { - globally consistent }\end{array}$ & $\begin{array}{l}\text { - limited ability to } \\
\text { develop good } \\
\text { models for tropical } \\
\text { forests } \\
\text { - spectral indices } \\
\text { saturate at rather } \\
\text { low } C \text { stocks } \\
\text { - can be technically } \\
\text { demanding }\end{array}$ & High \\
\hline & $\begin{array}{l}\text { Fine resolution } \\
\text { air-borne } \\
\text { optical remote } \\
\text { sensors }\end{array}$ & $\begin{array}{l}\text { Uses fine resolution ( } \\
10-20 \mathrm{~cm} \text { ) images to } \\
\text { measure tree height } \\
\text { and crown area and } \\
\text { allometry to estimate } \\
\text { carbon stocks (e.g. } \\
\text { aerial photos, 3-D } \\
\text { digital aerial imagery) }\end{array}$ & $\begin{array}{l}\text { - reduces time and cost } \\
\text { of collecting forest } \\
\text { inventory data } \\
\text { - reasonable accuracy } \\
\text { - excellent ground } \\
\text { verification for } \\
\text { deforestation baseline }\end{array}$ & $\begin{array}{l}\text { - covers only small } \\
\text { areas }(10,000 \text { ha) } \\
\text { - can be expensive } \\
\text { and technically } \\
\text { demanding } \\
\text { - allometric relations } \\
\text { based on crown } \\
\text { area are unavailable }\end{array}$ & $\begin{array}{l}\text { Low- } \\
\text { medium }\end{array}$ \\
\hline & $\begin{array}{l}\text { Radar remote } \\
\text { sensors }\end{array}$ & $\begin{array}{l}\text { Uses microwaves } \\
\text { or radar signal to } \\
\text { measure forest vertical } \\
\text { structure (e.g. ALOS } \\
\text { PALSAR, ERS-1, JERS-1, } \\
\text { Envisat) }\end{array}$ & $\begin{array}{l}\text { - satellite data are } \\
\text { generally free } \\
\text { new systems launched } \\
\text { in } 2005 \text { expected to } \\
\text { provide improved } \\
\text { data } \\
\text { can be accurate for } \\
\text { young or sparse forest }\end{array}$ & $\begin{array}{l}\text { - less accurate in } \\
\text { complex canopies } \\
\text { of mature forests } \\
\text { because signal } \\
\text { saturates } \\
\text { - mountainous terrain } \\
\text { also increases errors } \\
\text { - can be expensive } \\
\text { and technically } \\
\text { demanding }\end{array}$ & Medium \\
\hline & $\begin{array}{l}\text { Laser remote } \\
\text { sensors (e.g. } \\
\text { Lidar) }\end{array}$ & $\begin{array}{l}\text { Lidar uses laser light } \\
\text { to estimate forest } \\
\text { height and vertical } \\
\text { structure (e.g. Carbon } \\
\text { 3-D satellite system } \\
\text { combines Vegetation } \\
\text { canopy Lidar (VCL) } \\
\text { with horizontal } \\
\text { imager) }\end{array}$ & $\begin{array}{l}\text { - accurately estimates } \\
\text { full spatial variability } \\
\text { of forest carbon stocks } \\
\text { - potential for satellite- } \\
\text { based system to } \\
\text { estimate global forest } \\
\text { carbon stocks }\end{array}$ & $\begin{array}{l}\text { - airplane-mounted } \\
\text { sensors only option } \\
\text { - satellite system yet } \\
\text { unfunded } \\
\text { - requires extensive } \\
\text { field data for } \\
\text { calibration } \\
\text { - can be expensive } \\
\text { and technically } \\
\text { demanding }\end{array}$ & $\begin{array}{l}\text { Low- } \\
\text { medium }\end{array}$ \\
\hline
\end{tabular}




\subsubsection{Inventory approaches}

The updated IPCC greenhouse gas (GHG) accounting method (IPCC 2006) includes two approaches to estimating carbon stock changes (Brown and Braatz 2008; Figure 9.1): (i) the stock-based or stock-difference approach; and (ii) the process-based or gain-loss approach.

1) Stock-difference approach

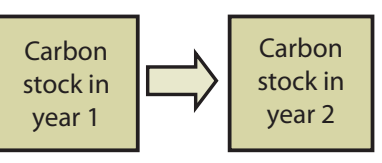

$\Delta \mathrm{C}=\left(\mathrm{C}_{\mathrm{t} 2}-\mathrm{C}_{\mathrm{t} 1}\right) /\left(\mathrm{t}_{2}-\mathrm{t}_{1}\right)$

Where

$\Delta C=$ Anual carbon stock change in pool (tC/yr)

$\Delta \mathrm{C}_{\mathrm{t} 1}=$ Carbon stock in pool at time $\mathrm{t}_{1}(\mathrm{tC})$

$\Delta \mathrm{C}_{\mathrm{t} 2}=$ Carbon stock in pool at time $\mathrm{t}_{2}(\mathrm{tC})$
2) Gain-loss approach

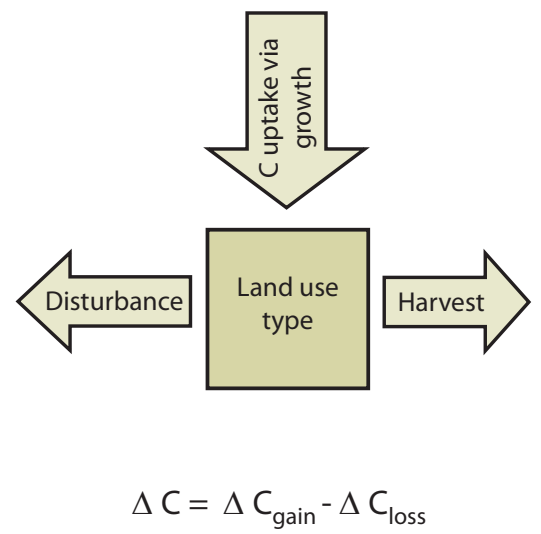

Where

$\Delta \mathrm{C} \quad=$ Anual carbon stock change in pool (tC/yr)

$\Delta \mathrm{C}_{\text {gain }}=$ Anual gain in carbon (tC/yr)

$\Delta \mathrm{C}_{\text {loss }}=$ Anual loss in carbon $(\mathrm{tC} / \mathrm{yr})$

Figure 9.1. Estimating carbon stock changes (Wertz-Kanounnikof 2008, adapted from Eggleston 2008, and Brown and Braatz 2008)

- Stock-difference approach: This method estimates the difference in carbon stocks in a particular pool at two moments in time. It can be used when carbon stocks in relevant pools have been measured and estimated over time, such as in national forest inventories. This approach is suitable for estimating emissions caused by both deforestation and degradation, and it can be applied to all carbon pools.

- Gain-loss approach: This approach estimates the net balance of additions to and removals from a carbon pool. In the REDD context, depending on how ecosystem rehabilitation is treated, gains result from growth and carbon transfer between pools (e.g. biomass pool to a dead organic matter pool due to disturbance). Hence, losses result from carbon transfer to another pool and emissions due to harvesting, decomposition or burning. ${ }^{4}$

4 When trees are cut down, there are three destinations for the stored carbon: dead wood, wood products and the atmosphere (Pearson et al. 2008). 
This method is used when annual data on information such as growth rates and wood harvest are available. In reality, a mix of the stock-difference and gain-loss approach can also be used.

\subsubsection{Inventory complexity}

IPCC methods allow for inventories with different levels of complexity, called Tiers. In general, inventories using higher tiers have improved accuracy and reduced uncertainty. There is a trade-off, however, as the complexity and resources required for conducting inventories also increase for higher tiers. A combination of tiers can be used, e.g. Tier 2 can be used for biomass and Tier 1 for soil carbon, depending on data availability and the magnitude of expected changes in the pool.

Tier 1 methods are designed to be simple to use. The IPCC guideline provides equations and default parameter values (e.g. emission and stock change factors), so the inventory compiler does not need specific data for these elements of the equations. Country-specific land use and management data are needed, but for Tier 1 there are often globally available sources for these estimates (e.g. deforestation rates, agricultural production statistics, global land cover maps, fertiliser use, livestock population data). The Tier 1 method alone, however, is unlikely to be sufficient for crediting under REDD.

Tier 2 uses the same methodological approach as Tier 1, but the emission and stock change factors are based on country or region-specific data. Countrydefined emission factors are more appropriate for the climatic regions and land use systems in the country or region. Higher temporal and spatial resolution, and more disaggregated land use and management categories are used in Tier 2 to correspond with country-defined coefficients for specific regions and specialised land use categories.

For Tier 3, higher order methods are used, including models and inventory measurement systems tailored to address unique national circumstances. Assessments are repeated over time and employ high-resolution land use and management data, which are generally disaggregated at subnational level. These inventories use advanced measurements and/or modelling systems to improve the estimation of GHG emissions and removals beyond what is possible with Tier 1 or 2 approaches. 


\subsection{Integration of MRV methods into a REDD mechanism}

While there has been significant progress on the technical aspects of carbon accounting, many developing countries lack access to data, as well as the technical infrastructure and capacity for consistent, transparent data analysis and management. In addition, MRV for REDD requires forest inventory institutions for ground-based measurements, quality control and external verification.

In the early stages of any REDD scheme, most countries will likely use a stock-difference method. As capacity is built, however, greater efficiency may come from emission-based (gain-loss) approaches since they allow for direct measurement of net changes in emissions. It is also highly likely that many countries can only implement a Tier 1 accounting scheme in the early stages. In these cases, conservative estimates of emissions reductions may be used for crediting (Eliasch 2008).

At COP 15 in Copenhagen in 2009, the global community may only agree on a first round REDD scheme and set developing country responsibilities (Stern 2008). A build up period of, say, 10 years may be needed to build effective and cooperative institutions, technology, and national capacity for cost-efficient monitoring and measuring at various scales (local to national). During this phase, countries that have limited abilities to implement higher Tier accounting could participate using Tier 1 approaches coupled with conservative estimates for crediting. Capacity building programmes by countries who can implement Tier 2 and 3 inventories are needed to raise the technical level of other participants. The ultimate trajectory of a REDD scheme, and how it will be integrated into any future climate regimes, remains unclear. If REDD becomes integrated into carbon markets, higher levels of accounting accuracy will be required because international buyers will want assurance that real emissions reductions have actually occurred. From a policy standpoint, one objective may be to create a favourable environment that promotes evolution towards higher Tier accounting approaches with greater accuracy and lower uncertainty. Such a transition phase is crucial for countries with currently weak MRV structures to avoid the risk of being excluded from a high standard mechanism, while giving them opportunity to improve their MRV methods and structures.

Establishing an independent international forest carbon monitoring institution for REDD or developing this capacity in an existing institution may be another way to overcome capacity shortcomings. This institution is not meant to replace the UNFCCC's framework for MRV, but to build synergies in addressing REDD monitoring requirements. Central African Forest Commission countries, for example, are establishing a regional institution called the Central African Forest Watchdog. Monitoring for carbon crediting purposes needs to be accurate, objective and reliable. Leaving this task to each REDD supplier 
country may create an incentive for biased monitoring (e.g. exaggerated emission reductions) to reap carbon benefits. This system of external validation provides a level of control against abuses, but it adds transaction costs as well. Independent third party monitoring and certification, in the form of an international forest carbon monitoring institution, may therefore be a better alternative. Centralising this task at the global level can enhance economies of scale and improve monitoring cost-effectiveness - compared with trying to ensure coherent monitoring by each country - and provide more coherent timeseries of deforestation data for baseline purposes. It has been estimated that a regional monitoring partnership among Cameroon, Democratic Republic of the Congo, Republic of the Congo, Equatorial Guinea and Gabon in Central Africa could save more than USD 2.2 million in setup costs in the first year, and more than USD 0.5 million in annual running costs (Hardcastle et al. 2008).

Capacity consists not only of the availability of technical equipment or costly satellite imagery, but also - and often more importantly - of know-how. This refers to the expertise in data cleaning, processing and analysis, and the use of data in the political process. The latter implies that capacity building needs to occur not only at the technical level (i.e. in the forest monitoring agency), but also at the political and institutional levels. For example, policy-makers need to have at least a minimum understanding of how changes in forest carbon affect the national REDD arrangements, and how this will relate to other sectoral policies.

Another constraint to monitoring emissions from deforestation and degradation is the limited knowledge of carbon stocks contained in alternative forest types and forest uses. To address this, Costa Rica, for example, advocates the introduction of a 'conservativeness principle' to reduce the risk of overestimation (see Appendix). This might take the form of countries being paid at the lower end of the $95 \%$ confidence interval. Although default data and IPCC guidelines exist to ensure the use of 'conservative' estimates, further effort is needed in spatially explicit forest carbon stock inventories. Lidar sensors are particularly promising for future forest carbon stock measurements. Given the rising monitoring needs for REDD and the huge potential of Lidar sensors to improve biomass estimates, the Earth Observation community should consider deploying such a platform in the near future. New investments could also focus on promoting operational research for future Lidar-based biomass monitoring at the global level.

Because of limited availability of large-scale Lidar imagery until at least 2015-2017, efforts need to be dedicated to making maximum use of currently available alternatives (e.g. ground-based measurements, Geographic Information Systems models to extrapolate sample data). Priority activities should include the establishment of allometric relationships for different forest types and management regimes. The conclusions from a recent UNFCCC expert meeting on MRV for degradation recognised that important data and 
knowledge gaps exist. The experts recommended getting on with the job of making MRV schemes workable and cost effective using existing technology, rather than delaying actions waiting for improved technology (UNFCCC 2008b).

\subsection{Conclusion}

We set out to demonstrate that the state of the art and science of carbon accounting should not be a constraint on incorporating REDD into future climate change regimes. We have presented a summary of recent advances in IPCC GHG accounting methods and new technological advances to improve the quality of data used in these methods. We have also pointed out remaining limitations and opportunities for overcoming them.

Given the recent advances outlined in this paper, we believe that viable REDD measurement and validation systems can be implemented. We realise that the capacity to implement these systems across major forested countries is uneven. A policy environment that encourages innovation to improve efficiency and provides capacity building support will contribute to making REDD an important element in combating climate change. A phased approach to allow for capacity building and to let countries gain experience, with eventual integration of the REDD mechanism into credit trading schemes or other elements of a future climate regime, will ensure sustainability of the reduced emissions.

For the debate on REDD MRV to move forward, the UNFCCC COP-14 in Poznan will need to clarify (i) how forest degradation will be integrated into a future REDD scheme; (ii) who will monitor national and subnational REDD activity (whether this is a national or international responsibility); and (iii) what will be the base period or year for determining historic trends. In the preparation of a future REDD scheme, countries could further benefit from clear rules and guidelines, such as official 'good practice guidelines for REDD'. 
Often, the driving forces for forest degradation and deforestation are different. Also, degradation is not necessarily a precursor to deforestation. Forests can remain degraded for a long time and never become completely deforested. So, addressing deforestation does not automatically reduce rates of forest degradation. In addition, failing to include degradation in a REDD agreement would mean that considerable amounts of forest-based emissions would not be accounted for. For example, if a healthy primary forest with a crown cover of $70 \%$ degraded to a state where it only had a crown cover of $15 \%$, it would still be classified as 'forest' and the increase in emissions from degradation would not be accounted for.

This chapter focuses on the methods used to measure and monitor forest degradation. It complements and elaborates on Chapter 9, which focuses on both Ds - deforestation and forest degradation. The methods to measure and monitor forest degradation are discussed in terms of effectiveness in accounting for emissions, cost efficiency, and international equity issues. The discussion takes account of differing country circumstances.

\subsection{Definition and causes of forest degradation}

As adopted at COP 9 in 2003, forest degradation is defined as 'direct humaninduced long-term loss (persisting for $\mathrm{X}$ years or more) of at least $\mathrm{Y} \%$ of forest carbon stocks (and forest values) since time ( $\mathrm{T}$ ) and not qualifying as deforestation' (IPCC 2003a). However, reaching agreement on an operational procedure for monitoring, reporting and verifying (MRV) forest degradation has been problematic (Penman 2008). This is because $X$ (human-induced long-term loss), Y (\% of forest carbon stocks) and the minimum area of forest to be measured are difficult to define. Each factor is influenced by the activities causing degradation and the ecology of the particular forest.

Common activities causing forest degradation in the tropics include (GOFCGOLD, 2008):

- Selective logging

- Large-scale and open forest fires

- Collecting non-timber forest products and wood for fuel

- Producing charcoal, grazing, subcanopy fires and shifting cultivation

Apart from selective logging, there have been few analyses of the impacts of these activities on the loss of forest biomass and how long forests need to regenerate. Further, almost all studies have focused on humid tropical forests. However, extracting fuelwood from dry forests often causes more degradation than commercial timber harvesting (Skutsch and Trines 2008). This is important 
since dry forests are generally more heavily populated than rainforests. While the carbon content of dry forests is much lower than that of humid forests, dry forests account for $42 \%$ of tropical forests (Murphy and Lugo 1986).

\subsection{Methods for estimating emissions from forest degradation}

The IPCC (2003b) identifies five carbon pools that should be monitored to estimate emissions from deforestation and forest degradation: aboveground biomass, belowground biomass, litter, dead wood and soil organic carbon. The most practical method of estimating emissions is to monitor only aboveground biomass. However, degradation processes such as logging and burning can significantly influence emissions from other carbon pools such as dead wood and litter.

The IPCC (2003b) also provides three tiers for carbon accounting. Each tier requires more data and more complex analyses and, therefore, is more accurate:

- Tier 1 applies default emission factors (indirectly estimates emissions based on the loss of canopy cover) to data on forest activities ('activity data') that are collected nationally or globally

- Tier 2 applies country specific emission factors and activity data

- Tier 3 applies methods, models and inventory measurement systems that are repeated over time, driven by high resolution activity data and disaggregated subnationally at a fine scale

Monitoring, reporting and verifying (MRV) deforestation and degradation has two components: (i) monitoring changes in forest area by forest type; and (ii) monitoring average carbon stocks per unit area and forest type (carbon densities) (IPCC 2003b). Thus, the simplest approach (Tier 1) keeps track of changes in the area of each category of forest, and calculates carbon stocks in each forest category using global default values for carbon densities. In Tier 2, the accuracy improves because carbon densities are estimated using country specific data instead of global default values. In Tier 3, models and inventories are tailored to the particular country and repeated over time. Thus Tier 3 also measures changes in carbon densities within the accounting period.

Changes in forest area can be monitored by remote sensing, at least in part, or by systematic forest inventories. Inventories need to be based on a sample large enough to detect significant changes in forest area by forest type. Monitoring forest degradation (i.e. the change from intact forest to disturbed forest) by remote sensing is much more challenging than monitoring deforestation. Deforestation is easily detected by remote sensing, particularly when it occurs 
on a large scale. However, it is much more difficult to detect degradation because remote sensing does not clearly show, for example, the removal of a few trees (selective logging) or loss of undergrowth (by fire) or disappearance of branches and small trees (for fuelwood). These activities have little effect on the canopy cover but can affect the forest stock significantly (DeFries et al. 2007). Even with high resolution optical imagery it is hard to detect changes under the canopy: advanced methods such as radar, which do have this potential, are currently only available in small areas.

One way of dealing with this problem is to use a probabilistic approach. This involves stratifying forest by risk of degradation, based on past trends and proxy variables such as accessibility (e.g. density of roads, distance from settlements) (Schelhas and Sanchez-Azofeifa 2006). The parameters in the models would be different for different types of degradation activities (e.g. selective logging, collecting fuelwood) (Iskandar et al. 2006).

Changes in average carbon stocks per unit area per forest type can be monitored by various methods. These include making use of secondary datasets and estimates from IPCC (2003b), as well as carrying out in situ forest inventories and monitoring sample plots. To measure changes in carbon stocks caused by forest degradation, IPCC (2006) recommends two methods: the stockdifference method and the gain-loss method (see Figure 9.1).

The stock-difference method builds on traditional forest inventories to estimate sequestration or emissions. The gain-loss method builds on an understanding of the ecology of forests: how forests grow, and how natural or anthropogenic processes produce carbon losses. The stock-difference method measures the actual stock of biomass in each carbon pool at the beginning and end of the accounting period. The gain-loss method estimates biomass gains as mean annual increment (MAI) in biomass minus estimated biomass losses from activities such as timber harvesting, logging, collecting fuelwood and overgrazing, as well as from fire. If the forest is stratified into areas subject to different kinds of degradation, and these are well understood, it may be possible, for example, to estimate the quantity of wood products extracted in a given period quite accurately.

Table 10.1 compares the stock-difference method with the gain-loss method. Both methods could be used for assessing forest degradation in IPCC Tiers 2 and 3. The choice of method will depend largely on what data are available and what resources are needed to collect additional data (GOFC-GOLD 2008). Countries experiencing significant forest degradation may wish to develop their own national and local databases and models in order to use the gain-loss method to estimate changes in different carbon pools. Estimates by Hardcastle and Baird (2008) suggest that adding degradation to the Tier 3 reporting setup would cost the Democratic Republic of the Congo an additional 10\%, 
Indonesia an additional $11 \%$ and Brazil an additional 13\%. The percentage increases in recurrent costs would be similar. However, these calculations assume that these countries are already reporting in Tier 3 and will therefore have robust sampling systems (covering a minimum of $3 \%$ of land surface and 6 strata) in place.

Table 10.1. Comparison of stock-difference and gain-loss methods for estimating emissions from different types of degradation

\begin{tabular}{|c|c|c|}
\hline $\begin{array}{l}\text { Type of } \\
\text { degradation }\end{array}$ & Stock-difference method & Gain-loss method \\
\hline $\begin{array}{l}\text { Selective } \\
\text { logging }\end{array}$ & $\begin{array}{l}\text { - Legal harvesting usually requires } \\
\text { measurement of biomass after } \\
\text { harvesting, thus necessary data } \\
\text { should be available } \\
\text { - Illegal harvesting would require } \\
\text { additional data collection } \\
\text { Data on undisturbed forest can be } \\
\text { used as a proxy if pre-harvesting } \\
\text { data for particular sites is not } \\
\text { available }\end{array}$ & $\begin{array}{l}\text { - Uses estimates of MAI and } \\
\text { centralised records on } \\
\text { timber extraction activities } \\
\text { - Reliability depends } \\
\text { on honesty of timber } \\
\text { companies in reporting rates } \\
\text { of extraction }\end{array}$ \\
\hline $\begin{array}{l}\text { Large-scale } \\
\text { forest fires }\end{array}$ & $\begin{array}{l}\text { Reference data from undisturbed } \\
\text { forest can be used for pre-fire } \\
\text { biomass, but forest inventory } \\
\text { would be needed to measure post- } \\
\text { fire biomass }\end{array}$ & $\begin{array}{l}\text { - Losses due to fire can be } \\
\text { estimated from the area } \\
\text { burned. Emission factors } \\
\text { can be used to estimate } \\
\text { emissions based on the } \\
\text { biomass lost }\end{array}$ \\
\hline $\begin{array}{l}\text { Harvesting of } \\
\text { fuel wood and } \\
\text { non-timber } \\
\text { forest products }\end{array}$ & $\begin{array}{l}\text { - Pre-harvesting biomass levels } \\
\text { could be estimated from typical } \\
\text { levels in undisturbed forest. But, } \\
\text { in practice, much of the forest } \\
\text { subject to these uses will already } \\
\text { be partially degraded at the start } \\
\text { of the accounting period } \\
\text { - In areas already under individual } \\
\text { or community management, pre- } \\
\text { and post-period forest inventories } \\
\text { can be carried out by forest users }\end{array}$ & $\begin{array}{l}\text { Data on losses, e.g. registers } \\
\text { of commercial wood- } \\
\text { based products, estimates } \\
\text { of fuelwood use, may be } \\
\text { available } \\
\text { - Fuelwood off-take could } \\
\text { also be calculated using } \\
\text { population and data } \\
\text { on average household } \\
\text { fuelwood consumption } \\
\text { - Data on gains are available } \\
\text { from standard MAl statistics }\end{array}$ \\
\hline $\begin{array}{l}\text { Subcanopy } \\
\text { fire, grazing } \\
\text { and shifting } \\
\text { cultivation } \\
\text { (using forest } \\
\text { for agricultural } \\
\text { production) }\end{array}$ & $\begin{array}{l}\text { Pre-harvesting biomass levels } \\
\text { could be estimated from typical } \\
\text { levels in undisturbed forest. But, } \\
\text { most forest subject to these } \\
\text { changes will already be partially } \\
\text { degraded at the start of the } \\
\text { accounting period } \\
\text { Communities can measure } \\
\text { changes. This can help establish } \\
\text { local 'ownership' of the process }\end{array}$ & $\begin{array}{l}\text { - Data on gains are available } \\
\text { from standard MAI statistics } \\
\text { - Data on losses are rarely } \\
\text { available in national } \\
\text { statistics }\end{array}$ \\
\hline
\end{tabular}




\subsection{Cost implications for countries}

The cost of measuring and monitoring forest degradation depends on the circumstances in each country, such as:

- The extent of forest cover

- The level of forest stratification (for example, the Democratic Republic of the Congo has only one major forest type whereas Indonesia and Mexico have four or more forest ecotypes)

- The tier of carbon accounting applied

Countries' forests are at different points on the forest transition curve (Figure 10.1), reflecting the changes in agriculture and forest rents over time (Angelsen 2007). As a result, degradation is a more critical issue in some countries than in others. For example, some countries may have halted deforestation but may still be losing biomass from the forests that remain. Thus, the state of a country's forests will influence to what extent it invests in forest degradation accounting systems and which measurement and monitoring option it chooses.

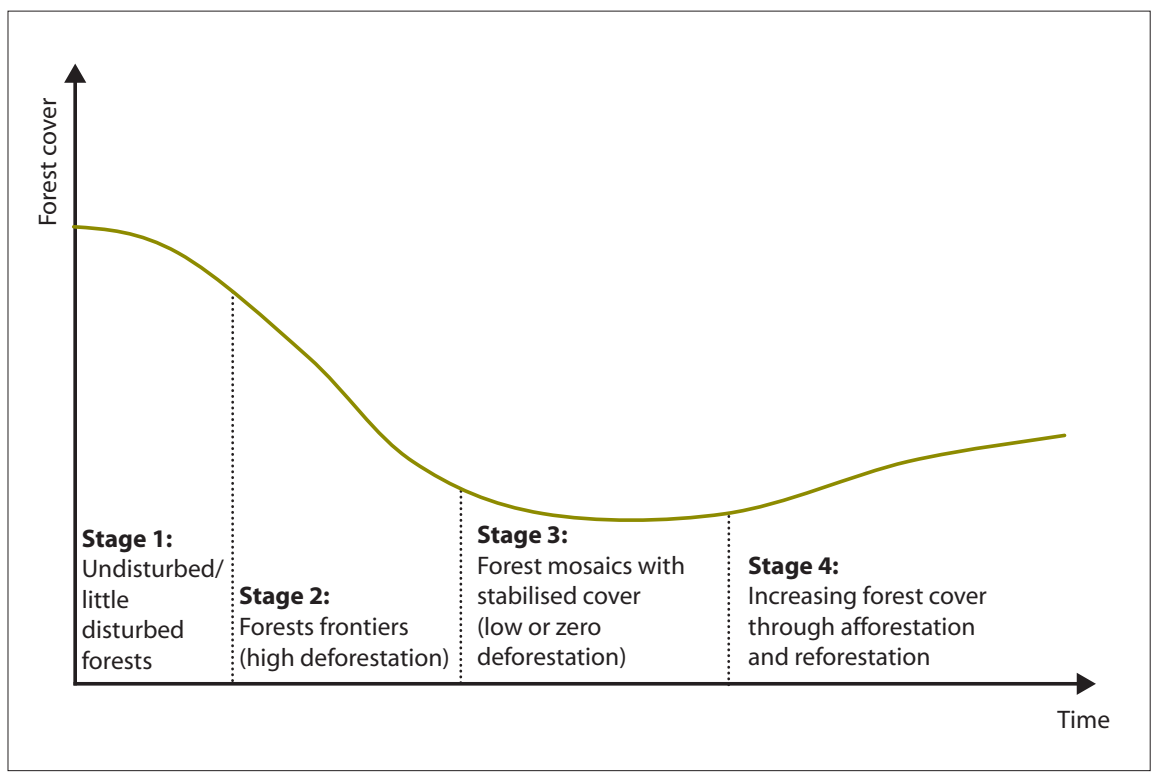

Figure 10.1. Stages in forest transition (adapted from Angelsen 2007)

Forest transition theory identifies four stages in the transition of forests. Countries can be grouped into four categories according to the stage their forests fall in:

1. Countries and regions with low deforestation and high forest cover such as the Congo Basin and Guyana - Here, forests are relatively undisturbed, but may be subject to increasing deforestation and degradation in the 
future. These countries and regions are likely to be the most interested in accounting for forest degradation because they are less likely to benefit from 'avoiding deforestation', at least if reference levels are based on historical deforestation. In these countries with intact forests, the stockdifference method with stratified sampling would be the most cost-efficient way of carbon accounting. Proxies could be used if there is no data from before logging or other human interventions (Table 10.1). Countries with large logging concessions could use the gain-loss method cost effectively because the basic data for Tier 2 type of reporting would be available. These countries could be motivated to account for degradation by the expectation that they could obtain financial support to do so.

2. Countries with high deforestation such as (parts of) Brazil, Indonesia, and Ghana that have large tracts of forest with high deforestation rates (forest frontiers) - These countries have a strong incentive to engage in deforestation accounting. Unless it requires little additional effort, they are less likely to have a significant interest in accounting for forest degradation. However, excluding forest degradation from national REDD schemes (especially where selective logging predominates) might lead to considerable leakage. These countries would most likely prefer to use the gain-loss method for the same reasons as countries in Category 1 with large logging concessions.

3. Countries with low deforestation and low forest cover characterised by forest mosaics and stable forest areas - In these countries, deforestation rates have levelled off, either because forests have already been largely cleared or because they have strong forest protection policies. India may fall in this category and, as indicated in their 2008 submission to the UNFCC, they may be interested in reducing degradation, probably in combination with forest conservation, afforestation and reforestation, and other schemes to enhance forest carbon stocks. These countries could use the stock-difference method in Tier 2. As site-specific data becomes more widely available and cost effective they could progress to Tier 3.

4. Countries with increasing forest cover such as China and Vietnam - These countries may not be very interested in accounting for forest degradation unless a REDD agreement includes 'enhancing' carbon stocks (Chapter 2). However, even though new plantations may increase the forest area in these countries, the existing forests may be simultaneously degrading. Countries may prefer to present their success in increasing the area of forest plantations as afforestation/reforestation (A/R) under the Clean Development Mechanism. Whether or not this happens depends on whether or not $\mathrm{A} / \mathrm{R}$ is integrated into a REDD agreement. Because they may have records of forest management going back some time, these countries may have databases that can provide historical reference scenarios, enabling them to adopt the stock-difference method in Tier 3. 


\subsection{Conclusion}

Forest degradation is more complicated to define, monitor, report and verify (MRV) than deforestation (IPCC 2003a). More proxy factors need to be used. But IPCC stock-difference and gain-loss methodologies (IPCC 2006) and tiers (IPCC 2003b) are useful for carbon accounting in forest degradation. Where data is limited, simple methods, default values (Tier 1), and proxies can be used to account for emissions from different kinds of degradation. The uncertainties inherent in simpler approaches mean that credits would need to be 'discounted'. This would be a direct incentive for countries to upgrade their measuring and monitoring methods.

Overcoming the challenges posed by carbon accounting in forest degradation by using the IPCC stock-difference and gain-loss methodologies, and tiers, means that forest degradation could realistically be included in a REDD agreement. This would make REDD more effective because it would account for a wider range of forest greenhouse gas emissions. The international equity of the REDD mechanism would also improve because a wider range of countries, many of them in Africa, would be encouraged to participate. It is, therefore, important that decisions on the MRV framework for degradation allow for a diversity of circumstances. This can be done by allowing countries flexibility in designing, developing and applying carbon accounting methods for forest degradation. 
Parties to the UNFCCC have thus recognised that REDD will have implications beyond mitigation of carbon emissions. This chapter deals with these broader dimensions or 'co-benefits' of REDD, focusing on:

- social co-benefits associated with pro-poor development;

- protection of human rights and improvement in forest governance; and

- environmental co-benefits, particularly enhanced biodiversity protection and soil and water quality and availability.

The chapter considers the extent to which the various REDD design options discussed in previous chapters can be made compatible with desired co-benefits, and avoid doing harm. Accordingly, for each of the three sets of co-benefits, this chapter will briefly summarise:

- opportunities and challenges of direct relevance to negotiations on the global architecture of an agreement on REDD; and

- implications for REDD implementation at the national level and below.

REDD is being negotiated in the context of a number of international agreements and allied instruments that recognise the importance of social cobenefits in the management of forest resources. The 'Bali Road Map' refers to such instruments in the 'Indicative Guidance' for demonstration activities, which 'should be consistent with sustainable forest management, noting, inter alia, the relevant provisions of the United Nations Forum on Forests (UNFF), United Nations Convention to Combat Desertification and the Convention on Biological Diversity' (Decision 2/CP.13 - Annex). For example, Article 20 of the Convention on Biological Diversity asserts that economic and social development and poverty eradication are the first and overriding priorities of the developing country partners, and international support needs to be tailored accordingly. The UNFF non-legally binding instrument includes in its purposes to 'enhance the contribution of forests to the achievement of the internationally agreed development goals, including the Millennium Development Goals, with respect to poverty eradication and environmental sustainability...' (Paragraph II, Principle 1). Such agreements - as well as such instruments as the safeguard policies of multilateral development banks provide an emerging body of international norms relevant to REDD.

At the same time, there are strong arguments for keeping REDD simple, in that an overemphasis on co-benefit and safeguard requirements could overload the agenda and discourage investment. Thus, as with other REDD design elements discussed in this volume, potential trade-offs among effectiveness, efficiency, and equity must be taken into account. 


\subsection{Co-benefits for poverty reduction and enhanced equity}

The questions of whether and how social co-benefits should be factored into REDD design and delivery are hotly debated. There are two positions among those who favour inclusion of REDD in a climate change regime. Some argue that because the main aim of REDD is to tackle climate change, not poverty, the appropriate stance should be that of 'do no harm' to the poor. ${ }^{2}$ Others favouring a 'pro-poor' approach argue that REDD will not succeed unless co-benefits are delivered. This group views REDD as deriving much of its legitimacy and potential effectiveness from its ability to improve the welfare of the forest-dependent poor and foster development in some of the poorest regions of the world. The arguments in favour of a pro-poor approach are diverse and compelling (see Box 11.1).

\section{Box 11.1. Why should REDD be pro-poor?}

Moral arguments concern the need not only to ensure that any major international initiative aims at improving welfare and equity, but also to address the interests of those with legitimate rights to use the forest who might be adversely affected by internationally supported interventions.

Practical considerations relate to the fact that the immediate forest managers, who are often the forest-dependent poor, will need appropriate incentives to ensure the effectiveness of REDD.

Risk reduction arguments address the risk of local rejection, even social conflict, which could be a major disincentive to external investment, particularly given forestry's record as a highly charged policy arena.

Attractiveness of REDD investments will be greater for those investors whose motivations are related to corporate social responsibility if REDD delivers pro-poor benefits.

Political considerations: Much REDD investment is likely to come from international donors and development agencies for which social development is an underlying rationale.

Procedural matters: The UNFCCC recognises the importance of social issues, including poverty, as global priorities (Decision 2/CP.13).

2 For example, a 2007 submission to the UNFCCC by the Government of Tuvalu states that '...co-benefits may be possible but these should not outweigh the key principle of reducing emissions at the global level.' (UNFCCC 2007). 
REDD could well prove high-risk for the forest-dependent poor. Reasons include the multiplicity of interests and the polarisation of wealth and power of different stakeholders in the forest sector. However, REDD also provides important opportunities to reduce poverty and enhance equity by delivering significant financial flows to rural areas, which are among the most depressed and underfunded parts of most developing economies.

\subsubsection{Relevance to REDD architecture at the global Level}

Previous chapters of this volume have assessed the equity implications of various REDD design elements, and potential trade-offs with effectiveness and efficiency. Some of these are briefly summarised below.

Market vs. fund-based finance (Chapter 5): The design of REDD finance mechanisms will have important implications for poverty and equity. The most obvious differences are likely to be in the overall volume of finance delivered, with compliance markets likely to deliver streams of finance that are an order of magnitude greater than concessional funding. However, market-based systems have two major limitations. First, markets are unlikely to fund the major public goods aspects of REDD delivery, particularly REDD preparedness. There is the risk that financing of REDD preparedness will be confined to the politically less challenging aspects (for example, developing technical monitoring capacity), to the detriment of major policy and institutional reforms that could help REDD realise its development potential (for example, forest tenure reforms).

Second, market finance is likely to be unevenly distributed between emerging economies (which tend to have quite well-elaborated legal frameworks and financial markets, conducive to private sector confidence) and less developed countries (which tend to be marked by 'poor governance'). Investors are unlikely to invest in countries where governance is problematic, thus concentrating investments in emerging economies, as has occurred with the Clean Development Mechanism (CDM) (Ebeling and Yasue 2008). The poorer the country, and the poorer the potential beneficiary groups within it, the smaller the likelihood of effective pre-financing of REDD-related activities by them.

In the short to medium term, governance considerations suggest that most REDD funding to less developed countries will come from discretionary aid donor and voluntary sources, not from compliance markets, although under some nested project arrangements, there may be potential for investment even in unfavourable national environments. In principle, donor financing should be more 'pro-poor' than compliance market finance, particularly as the lead agencies are mandated to promote development agendas. An alternative approach would involve use of a levy mechanism (for example, levying a fixed percentage from auctioning European Union Emissions Trading Scheme 
(ETS) revenues). This scheme could combine the benefits of market finance (it is estimated that a 5\% levy could generate EUR 2.5 billion by 2020) with the delivery of co-benefits, and thus has some attractions (Euractiv 2008). Despite its advantages, fund-based finance (whether development assistance or levy-based) weakens the link between payment and performance, and risks repeating the poor record of traditional aid to the forestry sector.

Scope and forest definitions (Chapter 2): The scope of REDD and the definitions of 'forest' have important implications on which countries and groups may benefit from REDD financial flows. The inclusion of degradation, for example, has different effects in countries where deforestation is mostly through industrial land conversion (e.g. Brazil) from countries where deforestation is driven more gradually by smallholder agriculture and demand for fuelwood and charcoal (e.g. many countries in Africa). Thus, accepting a definition that includes degradation as well as deforestation potentially widens the scope to reward the carbon conserving activities of the poor. A potential negative impact is that activities viewed as carbon degrading (swidden cultivation, for example) might be treated oppressively. On the other hand, narrow definitions ${ }^{3}$ could soak up most of the available finance at the expense of pro-poor interventions.

Risk and liability (Chapter 8): Issues of risk and liability are central concerns of compliance markets. Many international buyers will be motivated by the desire to transact high volumes at minimum risk, and pro-poor activities may be discounted on both fronts. Making national authorities bear all the delivery risk could severely reduce their willingness to invest in pro-poor activities. National authorities are also less likely to pass on any pre-financing they receive to rural communities. Downstream liability (should the scheme in question fail to deliver the promised emissions reductions) could be problematic for poor actors and communities if their governments, on behalf of investors, were to transfer liability to them.

Scale (Chapter 4): The architecture developed to nurture REDD activities will also affect the quality of pro-poor reforms, and there are some important effects of the scale chosen. For example, a nested approach in which liability initially accrues at project level will favour project interventions, with the strengths and weaknesses typical of this modality. If payments are being received and accounted for at project level, this may facilitate tight management, but it may be difficult to inform or influence the wider policy milieu which has the greatest impact on drivers of deforestation. An approach that focuses on national-level actions and encourages financial flows to be aligned with national budgetary processes and harmonised with national poverty strategies will have greater potential to influence the policy environment, although it will be more vulnerable to governance failures and corruption.

3 For example, definitions that view 'forests' as coterminous with production and protection forests, and focus attention on rewarding industrial logging companies for enhancing their carbon retention. 


\subsubsection{Opportunities and challenges at the national level}

Though the international architecture will set the framework for REDD implementation, the realisation of co-benefits for poverty and equity will largely depend on the ways in which REDD incentive payments are translated into strategies for emissions reductions at the national level. Policies and measures could range from national-level policies (for example, removing subsidies that encourage deforestation and degradation, taxing land clearance, strategic planning of road systems) through improved industrial practices (such as support for timber certification and reduced impact logging), to initiatives that directly involve and affect the livelihoods of the poor (alternative livelihoods programmes, fire prevention strategies, agricultural intensification schemes aimed at reducing forest destruction, and improved off-farm employment).

While few REDD projects have so far been implemented - and those were only in the voluntary sector - there is nevertheless much relevant evidence from a generation of 'conservation and development' projects with essentially similar aims. There are various reasons why these projects have met with only limited success, which includes the failure of project proponents to articulate clear strategies linking project interventions to expected changes in conservation and development outcomes (Hughes and Flintan 2001). A key constraint to increasing rural incomes through sustainable forestry has been the insecurity of property rights of many of the forest dependent poor.

For REDD to be effective in reducing carbon emissions and generating significant co-benefits related to poverty reduction and equity, it will need to be integrated and aligned with broader economic development strategies. These include strategies designed to decrease dependence on forests and other natural resources, such as industrial growth and more effective educational and social service delivery (Byron and Arnold 1999). Governments will need to coordinate REDD with national poverty reduction strategies and associated support from international donors.

Finally, there is a case for using REDD-related financial resources to support local government reform processes and social capital development, not only to help channel financial flows to the actual forest managers, but also to improve broader forest governance. Through the vehicle of local government reform, REDD would have great potential to improve timber revenue capture and management, and to help local communities manage the local component of those revenues and deploy them for community benefit (cf. Larson and Ribot 2006). 


\subsection{Co-benefits for human rights and governance}

Much of the opposition against the inclusion of REDD in the global climate protection regime is based on concerns that REDD could have negative consequences for the protection of human rights and could slow or reverse nascent improvements in forest governance at the national level. By conferring new value on forest lands, REDD could create incentives for government and commercial interests to actively deny or passively ignore the rights of indigenous and other forest-dependent communities to access and control forest resources. Large new financial flows would likely fuel conflict and create new opportunities for corruption.

On the other hand, if REDD payments are contingent on performance, data on forest status and trends will have to be made publicly available, government and commercial interests will have to negotiate with people in a position to exercise effective stewardship over forest resources, and mechanisms for transparent and accountable financial transfers will need to be established. More generally, the heightened international scrutiny of forest management that will accompany REDD finance could strengthen the implementation of existing safeguards. All this could also have positive implications for human rights and governance.

\subsubsection{Relevance to REDD architecture at the global level}

A consideration that applies to decision-making at all levels is respect for procedural rights - access to information, participation in decision-making, and access to justice - as articulated in Principle 10 of the Rio Declaration (1992). The UN Convention on Access to Information, Public Participation in Decision-making and Access to Justice in Environmental Matters (the so-called 'Aarhus Convention') provides important guidance for citizen involvement in decision-making relevant to REDD implementation. It also requires signatories to promote its principles in international negotiations on the environment.

In the context of REDD negotiations, respect for procedural rights implies an obligation for governments to proactively provide their citizens with timely and relevant information and opportunities for meaningful participation in the design of REDD. Indigenous peoples advocates have decried the marginalisation of their voices in REDD debates. Other groups have proposed the establishment of formal advisory groups composed of indigenous peoples and civil society representatives to advise the various bodies of the UNFCCC on REDD design and implementation (Rights and Resources Initiative 2008). 
Independent monitoring and assessment mechanisms will be an important component of REDD architecture at the global level to mitigate the risk of 'disbenefits' related to human rights and governance. Such mechanisms could be mandated to assess the impacts of REDD interventions on human rights and governance, and thus serve as an early warning system to enable prompt course correction.

Certain REDD design elements to be agreed at the global level may risk increasing human rights and governance problems in the context of nationallevel implementation, or conversely, could enhance opportunities for positive co-benefits. For example, subnational approaches to REDD implementation would be more compatible with application of safeguards and other instruments for monitoring and verification of impacts on human rights. Conversely, national approaches offer greater upside potential to using REDD to improve forest governance, for example, through broad-based tenure reform. A combination of elements of centralised and decentralised approaches to forest governance may be needed to optimise the advantages and disadvantages of each (Colfer and Capistrano 2005).

REDD can also be linked to various international agreements that articulate the obligations of parties to protect human rights. For example, Colchester (2008: 5) sums up a number of international legal instruments related to the rights of indigenous peoples as asserting forest peoples' right to 'own, control, use and peacefully enjoy their lands, territories and other resources, and be secure in their means of subsistence'. An illustrative summary of these instruments is provided in Box 11.2.

In addition to rights and obligations articulated in international agreements, there is an emerging body of 'soft law' and international norms of relevance to REDD. Especially important for human rights and governance are procedural standards. The principle of 'free, prior and informed consent' (FPIC) on the part of affected communities affected by external development interventions is increasingly recognised as a standard to be achieved by governments and private corporations prior to infrastructure or extractive industry projects (Colchester and Ferrari 2007). Establishing FPIC standards in the context of REDD implementation could ensure greater procedural rights for affected communities.

\subsubsection{Opportunities and challenges at the national level}

Any REDD-induced changes in national-level forest governance are likely to have major effects on the well-being of forest-dependent populations, including indigenous peoples. Many poor communities have progressively lost their rights since colonial times, and have been effectively reduced to the status 


\section{Box 11.2. Illustrative international human rights instruments relevant to REDD}

The International Covenant on Economic, Social, and Cultural Rights asserts that 'In no case may a people be deprived of its own means of subsistence' (Article 1), suggesting an imperative that REDD not result in the denial of access to forestbased livelihoods.

The International Covenant on Civil and Political Rights provides guidance to ensure that human rights violations - such as arbitrary arrest and detention (Article 9) - do not result from repressive law enforcement-orientated approaches to achieve REDD objectives.

The United Nations Declaration on the Rights of Indigenous Peoples proclaims that 'States shall establish and implement, in conjunction with indigenous peoples concerned, a fair, independent, impartial, open and transparent process, giving due recognition to indigenous peoples' laws, traditions, customs and land tenure systems, to recognize and adjudicate the rights of indigenous peoples pertaining to their lands, territories and resources' (Article 27), a process that would need to precede REDD implementation.

The Convention on Elimination of All Forms of Discrimination against Women affirms that development plans must take into account 'the particular problems faced by rural women and the significant roles which rural women play in the economic survival of their families, including their work in the non-monetized sectors of the economy' (Article 14), which is particularly significant in the case of forest resource use.

of squatters on public lands. Pursuit of livelihoods in such situations often involves behaviour that, however legitimate and necessary, is formally 'illegal', and this contributes to vulnerability. If poor people lack rights, it limits their power to negotiate for outcomes suitable to their interests, and they also suffer from their inability to defend the rights they do have (Khan 2006).

While there has been a recent modest increase in the proportion of forest lands designated for use or ownership by communities and indigenous peoples, most of the forests in countries likely to participate in a global REDD regime remain in the hands of governments (Sunderlin et al. 2008). Revaluation of forest resources through the establishment of carbon rights could discourage cashstrapped governments from conceding forest carbon rights to communities. Should REDD payments be contingent on performance, the tendency for governments to withhold rights would be countered.

Although REDD may also provide an opportunity for further progress in reformist legislation, special attention to safeguards is needed to ensure that the interests of national elites and international commercial interests do not override the rights of forest communities. Accordingly, international 
investments in REDD capacity building efforts should enhance the ability of duty bearers (including government agencies, corporations, and nongovernmental organisations) to guard against human rights violations in REDD implementation, and should promote the ability of rights holders to claim their rights.

\subsection{Co-benefits for biodiversity and other ecosystem services}

REDD has a large potential to generate co-benefits for biodiversity conservation and other ecosystem services (beyond carbon sequestration). Tropical forest conservation is widely viewed to have been significantly underfunded in recent decades, in terms of both scale and length of funding cycle (Balmford and Whitten 2003), and the financial flows associated with REDD offer radical new possibilities on both fronts.

With respect to biodiversity, REDD avoids many of the pitfalls of Afforestation/ Reforestation (A/R) schemes, which tend to favour monocultures of exotic species. Plantation monocultures are not without biodiversity value, but in general support only a small proportion of the biodiversity of typical natural forest ecosystems (Kanowski et al. 2005). Compared with A/R schemes, REDD probably also has the advantage of not requiring over-demanding biodiversity standards, given that much forest conservation is likely to be inherently good for biodiversity.

REDD can also be expected to provide co-benefits in terms of hydrological and soil conservation services. REDD could also help control soil erosion, and this affects both water and soil quality. Globally, three quarters of usable freshwater supplies come from forested catchments (Fischlin et al. 2007). Bundling carbon conservation with other ecosystem services such as water catchment could provide win-win scenarios.

More broadly, the large-scale forest conservation that REDD could bring about could also have positive impacts on the climate beyond provision of carbon sequestration services. Bruijnzeel (2004), for example, predicts that large-scale conversion of forests to pastureland in Amazonia might result in a seven percent reduction in annual rainfall. Avoiding such impacts could have wider environmental benefits and help avoid the major changes in climate that are anticipated as likely to occur (Nepstad 2007). 


\subsubsection{Relevance to REDD architecture at the global level}

To some extent, REDD at any scale is likely to have positive impacts on biodiversity, although the various design options may have differing impacts. REDD funding, particularly if funds come from markets, is likely to be directed towards areas of high carbon emissions. This will ensure high carbon effectiveness, but these areas are not necessarily the areas of highest biodiversity. Already protected areas such as the indigenous reserves which cover 22 percent of the Brazilian Amazon, and other biodiversity hotspots such as the Guiana Shield, would be unlikely to benefit, at least initially (da Fonseca et al. 2007). By contrast, voluntary stock maintenance and fund-based REDD schemes could potentially capture a larger set of co-benefits for biodiversity through broader geographic targeting, but the levels of funding would likely be significantly lower. Thus, although carbon and biodiversity aims are largely compatible, there could be trade-offs in the geographical targeting of funds.

From a biodiversity perspective, national systems are preferable to projectbased approaches, in that they are likely to promote a more rational approach to landscape planning. The economies of scale in national-level measurement and monitoring systems will also facilitate planning at the landscape level. Project approaches, although prone to leakage (Chapter 7) may be 'good for biodiversity' by allowing investors to target specific areas with high biodiversity value. For example, the Noel Kempff Mercado Park in Bolivia, which is one of the few examples of a voluntary REDD scheme, has consolidated forest fragments into more ecologically coherent units despite concerns about leakage beyond its boundaries (Robertson and Wunder 2005).

The extent to which REDD finance flows to dry forests will be influenced by a number of global design elements, including reference levels, financing mechanisms, and whether the scope includes avoided degradation. Should REDD design facilitate targeting of forestlands covered under the UN Convention to Combat Desertification (UNCCD), this could have particularly important co-benefits in terms of combating soil erosion in those areas. However, such targeting would imply trade-offs in overall effectiveness and efficiency of the REDD mechanism, due to the significantly lower aboveground carbon stock of such areas compared to moist tropical forests.

Maintenance of major ecosystem functions suggests the need for coordinated landscape planning on an international scale, which is likely beyond the scope of an agreement focused on mitigation of carbon emissions. However, a number of international agreements are relevant to REDD delivery and encourage harmonisation with wider environmental objectives at national and regional scales. These include the UN Convention on Biological Diversity, the UNCCD, and the Ramsar Convention on Wetlands. 


\subsubsection{Opportunities and challenges at the national level}

The extent to which REDD policies and measures implemented at the national level will affect biodiversity and other ecosystem services will depend on existing land use options and strategies, the types of activities incentivised or prohibited, as well as their geographic targeting. Much will depend on the underlying drivers of deforestation, and the overall environmental impacts of alternative uses of forest lands.

For example, in areas of forest that would otherwise be subjected to conventional logging practices, REDD funds could contribute to biodiversity conservation if effectively deployed to incentivise Reduced Impact Logging (RIL) (Meijaard et al. 2005). Co-benefits would be even greater if logged-over forests would otherwise be at risk of conversion to agricultural production in the absence of REDD finance.

REDD strategies intended to wean farmers away from destructive cyclical cultivation practices may appear positive for biodiversity, but the impact would need to be established for each situation. Farm bush biomes typical of shifting cultivation may have high biodiversity, for example (Tutin and Fernandez 1985), compared to permanent agriculture alternatives. Improving the productivity of cyclical practices and/or agroforestry systems may be better for biodiversity. Beverage crops such as coffee may allow for the connectivity, which is conducive to maintaining ecosystem effects particularly where shade tolerant or dependent tree varieties are employed, but may require heavy chemical treatments to suppress fungal and pest attacks. Optimising REDD carbon sequestration objectives with other environmental co-benefits will thus need to take into account inputs and outputs over the whole agricultural cycle.

\subsection{Conclusion}

The challenge for the international community is to ensure that the global architecture that is put in place by the UNFCCC provides - and does not foreclose - opportunities for developing countries to implement REDD in ways that deliver co-benefits related to poverty reduction, human rights protection, and non-carbon ecosystem services, and that avoid doing harm. Benefits are likely to be greatest, and risks minimised, if REDD financial flows and national-level implementation are harmonised with other preexisting international commitments and emerging norms, as well as national development strategies.

A key challenge will be designing appropriate procedural standards - including assessment, monitoring and verification mechanisms - to ensure that due attention is paid to risks and opportunities without imposing excessive transaction costs that work to the detriment of achieving REDD objectives and co-benefits alike. 


\section{Appendix}

\section{Overview of REDD proposals submitted to the UNFCCC ${ }^{1}$}

Philippe Guizol and Stibniati Atmadja

\begin{tabular}{|c|c|c|}
\hline Issues & Opinions & Supported by \\
\hline \multicolumn{3}{|c|}{ Key design issues } \\
\hline \multirow[t]{6}{*}{ Guiding principles } & $\begin{array}{l}\text { Common, but differentiated, } \\
\text { responsibilities: Different national } \\
\text { circumstances across countries } \\
\text { will determine different levels of } \\
\text { participation and will require targeted, } \\
\text { positive incentives. }\end{array}$ & $\begin{array}{l}\text { Costa Rica (Apr. 08); } \\
\text { PNG - GRULAC - Costa } \\
\text { Rica (Mar. 07); Mexico } \\
\text { (Apr. 08); EU (Jul. 08) }\end{array}$ \\
\hline & $\begin{array}{l}\text { Emphasis on sovereignty or a nation's } \\
\text { right to self-determination and } \\
\text { economic development. Participation } \\
\text { in any future mechanism should be } \\
\text { voluntary, taking into account national } \\
\text { circumstances and existing policies } \\
\text { and initiatives. }\end{array}$ & $\begin{array}{l}\text { Costa Rica (Apr. 08); } \\
\text { PNG (Apr. 08); ACCRA } \\
\text { Working Group (Aug. } \\
\text { 08); Mexico (Apr. 08) }\end{array}$ \\
\hline & $\begin{array}{l}\text { Equity within countries: Participation } \\
\text { of stakeholders, local communities } \\
\text { and indigenous peoples should be } \\
\text { secured. Distribution of REDD benefits } \\
\text { to local actors should be transparent. }\end{array}$ & $\begin{array}{l}\text { ACCRA Working Group } \\
\text { (Aug. 08); Japan (Aug. } \\
\text { 08); PNG (Apr. 08) }\end{array}$ \\
\hline & $\begin{array}{l}\text { Equity across countries. Early action to } \\
\text { reduce DD should be rewarded. }\end{array}$ & $\begin{array}{l}\text { Costa Rica (Apr. 08); } \\
\text { CfRN (Sept. 07); Mexico } \\
\text { (Apr. 08) }\end{array}$ \\
\hline & $\begin{array}{l}\text { REDD complementary actions (Green } \\
\text { Fund) should involve all countries. }\end{array}$ & Mexico (June 08) \\
\hline & $\begin{array}{l}\text { REDD should also include low } \\
\text { deforestation countries. }\end{array}$ & Greenpeace (Mar. 08) \\
\hline
\end{tabular}

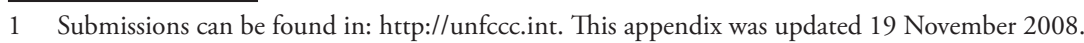




\begin{tabular}{|c|c|c|}
\hline Issues & Opinions & Supported by \\
\hline \multicolumn{3}{|c|}{ Key design issues (continued) } \\
\hline \multirow[t]{3}{*}{$\begin{array}{l}\text { Guiding principles } \\
\text { (continued) }\end{array}$} & $\begin{array}{l}\text { The current knowledge of } \\
\text { methodological issues is sufficient } \\
\text { to initiate discussions on policy } \\
\text { approaches and positive incentives. }\end{array}$ & $\begin{array}{l}\text { ACCRA Working Group } \\
\text { (Aug. 08) }\end{array}$ \\
\hline & $\begin{array}{l}\text { The need for immediate support } \\
\text { to host countries for governance } \\
\text { and capacity building at all levels in } \\
\text { developing countries. This includes } \\
\text { the need to promote both North- } \\
\text { South and South-South technology } \\
\text { transfer and technical cooperation. }\end{array}$ & $\begin{array}{l}\text { ACCRA Working Group } \\
\text { (Aug. 08); Brazil (Mar. } \\
\text { 07); COMIFAC (Apr. 08); } \\
\text { Costa Rica (Apr. 08); } \\
\text { CfRN (Sept. 07); Mexico } \\
\text { (Aug. 08); PNG (Apr. 08) }\end{array}$ \\
\hline & $\begin{array}{l}\text { Period up to } 2012 \text { should be devoted } \\
\text { to 'demonstration activities' and } \\
\text { 'national forest carbon inventory' } \\
\text { to facilitate integration of policy } \\
\text { approaches and design REDD } \\
\text { incentives at COP 15. Period after } 2012 \\
\text { should focus on policies and positive } \\
\text { incentives for REDD. }\end{array}$ & EU (Jul. 08) \\
\hline \multirow[t]{3}{*}{$\begin{array}{l}\text { Global institutional } \\
\text { setup }\end{array}$} & $\begin{array}{l}\text { Separate REDD treaty, with respect to } \\
\text { the Kyoto Protocol. }\end{array}$ & $\begin{array}{l}\text { Brazil (Mar. 07); CCAP } \\
\text { (Aug. 07); New Zealand } \\
\text { - separate but still } \\
\text { linked with Kyoto (Apr. } \\
\text { 08) }\end{array}$ \\
\hline & $\begin{array}{l}\text { REDD should be under UNFCCC and } \\
\text { integrated in a post- } 2012 \text { agreement. }\end{array}$ & $\begin{array}{l}\text { Mexico (Aug. 08); CfRN } \\
\text { (Sept. 07); Greenpeace } \\
\text { (Mar. 08); Norway (Sept. } \\
\text { 08) }\end{array}$ \\
\hline & $\begin{array}{l}\text { Under a preexisting institution (non- } \\
\text { UNFCCC), e.g. FCPF, UN-REDD. }\end{array}$ & $\begin{array}{l}\text { FAO, UNDP, UNEP (Apr. } \\
\text { 08); PNG (Apr. 08) }\end{array}$ \\
\hline \multirow[t]{3}{*}{ Scope of REDD } & $\begin{array}{l}\text { Afforestation/reforestation activities } \\
\text { could be included in a REDD scheme. }\end{array}$ & $\begin{array}{l}\text { India (Apr. 08); Japan } \\
\text { (Aug. 08) }\end{array}$ \\
\hline & $\begin{array}{l}\text { A REDD scheme should include carbon } \\
\text { stock enhancement and sustainable } \\
\text { forest management. }\end{array}$ & $\begin{array}{l}\text { Argentina, Honduras, } \\
\text { Panama, Paraguay and } \\
\text { Peru (Apr. 08); Costa } \\
\text { Rica (Apr. 08); India } \\
\text { (Apr. 08); Japan (Aug. } \\
\text { 08); Nepal (Apr. 08); } \\
\text { Indonesia (Apr. 08); } \\
\text { Norway (Sept. 08) }\end{array}$ \\
\hline & $\begin{array}{l}\text { Sustainable forest management, } \\
\text { carbon stock enhancement and forest } \\
\text { conservation are not, by themselves, } \\
\text { directly in line with avoiding emissions } \\
\text { from deforestation. }\end{array}$ & Colombia (Apr. 08) \\
\hline
\end{tabular}




\begin{tabular}{|c|c|c|}
\hline Issues & Opinions & Supported by \\
\hline \multicolumn{3}{|c|}{ Key design issues (continued) } \\
\hline $\begin{array}{l}\text { Scope of REDD } \\
\text { (continued) }\end{array}$ & $\begin{array}{l}\text { Additional actions should } \\
\text { complement REDD: as forest } \\
\text { management, carbon conservation, } \\
\text { combating fires and carbon } \\
\text { sequestration actions that result in } \\
\text { local and global co-benefits. }\end{array}$ & $\begin{array}{l}\text { Mexico (Aug. 08); Japan } \\
\text { (Apr. 08); EU (Jul. 08); } \\
\text { Indonesia (Apr. 08); } \\
\text { India (Apr. 08); Nepal } \\
\text { (Apr. 08); COMIFAC (Apr. } \\
\text { 08) }\end{array}$ \\
\hline \multirow[t]{3}{*}{$\begin{array}{l}\text { Activities credited } \\
\text { under REDD }\end{array}$} & $\begin{array}{l}\text { Input-based: Payments are made } \\
\text { conditional on the inputs made to } \\
\text { produce a desired outcome, even if } \\
\text { the outcome cannot be measured } \\
\text { directly, e.g. participatory forest } \\
\text { management, prevention of forest } \\
\text { fires and combatting illegal logging. }\end{array}$ & Japan (Aug. 08) \\
\hline & $\begin{array}{l}\text { Output-based: Credit for enhanced } \\
\text { carbon stocks and maintaining } \\
\text { baseline stocks. }\end{array}$ & India (Apr. 08) \\
\hline & $\begin{array}{l}\text { Mixed crediting approaches: (i) } \\
\text { unplanned deforestation and forest } \\
\text { degradation (DD) activities: credit } \\
\text { based on level of emission reduction } \\
\text { from activities compared to historical } \\
\text { emissions from such activities (as } \\
\text { forest management); and (ii) planned } \\
\text { DD activities: the carbon stock } \\
\text { saved by not implementing planned } \\
\text { conversion of natural forest. }\end{array}$ & Indonesia (Apr. 08) \\
\hline \multicolumn{3}{|c|}{ Cost, potential and risk } \\
\hline \multirow[t]{3}{*}{ Cost } & $\begin{array}{l}\text { Importance of adopting fair and cost- } \\
\text { effective means to reduce emissions } \\
\text { from DD in developing countries. }\end{array}$ & $\begin{array}{l}\text { ACCRA Working Group } \\
\text { (Aug. 08); COMIFAC } \\
\text { (Apr. 08) }\end{array}$ \\
\hline & $\begin{array}{l}\text { Transaction costs related to readiness } \\
\text { activities (e.g. capacity building). }\end{array}$ & $\begin{array}{l}\text { Congo Basin (Mar. } \\
\text { 07); CfRN (Sept. 07); } \\
\text { Indonesia (Aug. 08) }\end{array}$ \\
\hline & $\begin{array}{l}\text { Costs associated with meeting } \\
\text { international standards (e.g. } \\
\text { monitoring). }\end{array}$ & $\begin{array}{l}\text { PNG (Apr. 08); } \\
\text { BioCarbon (World } \\
\text { Bank) (Aug. 08) }\end{array}$ \\
\hline \multirow[t]{2}{*}{ Risks } & $\begin{array}{l}\text { REDD market may jeopardise the } \\
\text { integrity of existing carbon market } \\
\text { and efforts to reduce fossil fuel use. }\end{array}$ & $\begin{array}{l}\text { CCAP (Aug. 07); New } \\
\text { Zealand (Apr. 08) }\end{array}$ \\
\hline & $\begin{array}{l}\text { The supply and demand for REDD } \\
\text { credits is unknown, leading to risk } \\
\text { aversion among buyers and sellers. }\end{array}$ & $\begin{array}{l}\text { CCAP (Aug. 07); CISDL } \\
\text { and GPPI (Feb. 07); FAO, } \\
\text { UNDP, UNEP (Apr. 08); } \\
\text { New Zealand (Apr. 08) }\end{array}$ \\
\hline
\end{tabular}




\begin{tabular}{|c|c|c|}
\hline Issues & Opinions & Supported by \\
\hline \multicolumn{3}{|c|}{ Cost, potential and risk (continued) } \\
\hline \multirow[t]{3}{*}{$\begin{array}{l}\text { Risks } \\
\text { (continued) }\end{array}$} & $\begin{array}{l}\text { Land tenure issues should be } \\
\text { addressed by encouraging } \\
\text { institutional reforms and community } \\
\text { engagement as a way to mitigate the } \\
\text { risk of conflict. }\end{array}$ & $\begin{array}{l}\text { FAO, UNDP, UNEP } \\
\text { (Apr. 08) }\end{array}$ \\
\hline & $\begin{array}{l}\text { National REDD strategy should be } \\
\text { integrated into existing national } \\
\text { development planning as a way to } \\
\text { mitigate delivery risks. }\end{array}$ & $\begin{array}{l}\text { FAO, UNDP, UNEP } \\
\text { (Apr. 08) }\end{array}$ \\
\hline & $\begin{array}{l}\text { 'Hot air' risks can be mitigated by } \\
\text { storing credits issued during one } \\
\text { period for use during another period. }\end{array}$ & $\begin{array}{l}\text { CISDL and GPPI (Feb. } \\
\text { 07); Costa Rica (Apr. 08) }\end{array}$ \\
\hline \multicolumn{3}{|c|}{ Scale } \\
\hline \multirow[t]{2}{*}{$\begin{array}{l}\text { Subnational/ } \\
\text { Project approaches }\end{array}$} & $\begin{array}{l}\text { Project approaches should be allowed } \\
\text { for early startup, broad participation } \\
\text { and where they are attractive } \\
\text { to private investors. But project } \\
\text { approaches suffer from domestic } \\
\text { leakage and cover limited forest areas. }\end{array}$ & $\begin{array}{l}\text { BioCarbon (World } \\
\text { Bank) (Aug. 08) }\end{array}$ \\
\hline & $\begin{array}{l}\text { Subnational approaches help } \\
\text { garner the experience necessary to } \\
\text { implement national approaches. }\end{array}$ & COMIFAC (Apr. 08) \\
\hline $\begin{array}{l}\text { National } \\
\text { approaches }\end{array}$ & $\begin{array}{l}\text { National approaches allow for a broad } \\
\text { set of policies to be pursued, capture } \\
\text { domestic leakage and create country } \\
\text { ownership, but will only be feasible } \\
\text { for a small number of countries in the } \\
\text { short to medium term. Subnational } \\
\text { approaches may be appropriate in } \\
\text { some national circumstances as a step } \\
\text { towards the development of national } \\
\text { approaches, reference levels and } \\
\text { estimates. }\end{array}$ & $\begin{array}{l}\text { Brazil (Mar. 07); CCAP } \\
\text { (Aug. 07); CfRN (Sept. } \\
\text { 07); CISDL and GPPI } \\
\text { (Feb. 07); Colombia } \\
\text { (Apr. 08); COMIFAC } \\
\text { (Apr. 08); EU (Apr. 08); } \\
\text { FAO, UNDP, UNEP (Apr. } \\
\text { 08); Greenpeace (Mar. } \\
\text { 08); India (Apr. 08); } \\
\text { Indonesia (Apr. 0 8); } \\
\text { New Zealand (Apr. 08); } \\
\text { Norway (Sept. 08) }\end{array}$ \\
\hline Nested approach & $\begin{array}{l}\text { A nested approach offers a flexible } \\
\text { mechanism, allows for early startup } \\
\text { and supports projects. It supports } \\
\text { moves either towards a national } \\
\text { approach or towards coexistence of } \\
\text { project and national approaches in a } \\
\text { system where REDD credits are shared } \\
\text { between projects and governments. }\end{array}$ & $\begin{array}{l}\text { Costa Rica (Apr. 08); } \\
\text { Colombia (Apr. 08); } \\
\text { Paraguay, Argentina, } \\
\text { Honduras, Panama, } \\
\text { Peru (Apr. 08); PNG (Apr. } \\
\text { 08); Nepal (Apr. 08) }\end{array}$ \\
\hline $\begin{array}{l}\text { From global to } \\
\text { local approach }\end{array}$ & $\begin{array}{l}\text { Sharing tasks between global, } \\
\text { national, subnational and local actors. }\end{array}$ & Switzerland (Apr. 08) \\
\hline
\end{tabular}




\begin{tabular}{|c|c|c|}
\hline Issues & Opinions & Supported by \\
\hline \multicolumn{3}{|c|}{ Funding } \\
\hline \multirow[t]{7}{*}{$\begin{array}{l}\text { Sources of funding. } \\
\text { Non-market, dual } \\
\text { (both market } \\
\text { and non-market), } \\
\text { market based }\end{array}$} & $\begin{array}{l}\text { Prefer non-market based funding for } \\
\text { emission reduction incentives, new } \\
\text { and additional sources of funding } \\
\text { (from Annex I countries), public } \\
\text { funds (ODA), donations, financial } \\
\text { mechanisms under UNFCCC. }\end{array}$ & Brazil (Mar. 07) \\
\hline & $\begin{array}{l}\text { Dual, with main funding mechanism } \\
\text { through trust fund - Multi-Donor Trust } \\
\text { Fund (MDTF). }\end{array}$ & $\begin{array}{l}\text { FAO, UNDP, UNEP (Apr. } \\
08)\end{array}$ \\
\hline & $\begin{array}{l}\text { Dual. Additional funds for early action } \\
\text { or multiple funding sources. Funding } \\
\text { sources could be differentiated over } \\
\text { time. Short- and medium-term non- } \\
\text { market funds for capacity building and } \\
\text { other transaction costs, and long-term } \\
\text { market solutions for actual carbon } \\
\text { emission reductions. }\end{array}$ & $\begin{array}{l}\text { COMIFAC (Apr. 08); } \\
\text { CCAP (Aug. 07); EU (Apr. } \\
\text { 08, Jul. 08); CfRN (Sept. } \\
\text { 07); New Zealand (Apr. } \\
\text { 08); PNG (Mar. 07); PNG } \\
\text { (Apr. 08); Greenpeace } \\
\text { (Dec. 07); Norway (Sept. } \\
\text { 08) }\end{array}$ \\
\hline & $\begin{array}{l}\text { Dual. Non-market financing also } \\
\text { used to support new funds, such as } \\
\text { Community Forest Retention Trust } \\
\text { Fund, International Forest Retention } \\
\text { Fund, Compensated Conservation and } \\
\text { World Climate Change Fund. }\end{array}$ & $\begin{array}{l}\text { PNG (Mar. 07); Mexico } \\
\text { (Jun. 08) }\end{array}$ \\
\hline & $\begin{array}{l}\text { Preference for market-based rather } \\
\text { than funds-based, but open to explore } \\
\text { both options. }\end{array}$ & New Zealand (Apr. 08) \\
\hline & $\begin{array}{l}\text { Prefer market-based financing from } \\
\text { sale of emission reduction credits. }\end{array}$ & $\begin{array}{l}\text { Australia (Apr. 08); } \\
\text { Colombia (Apr. 08); } \\
\text { Costa Rica (Apr. 08); } \\
\text { CfRN (Sept. 07); PNG } \\
\text { (Mar. 07); CISDL and } \\
\text { GPPI (Feb. 07) }\end{array}$ \\
\hline & $\begin{array}{l}\text { Include funding from auctioning } \\
\text { carbon emissions allowances. }\end{array}$ & Norway (Sept. 08) \\
\hline \multirow[t]{2}{*}{$\begin{array}{l}\text { Recipients of } \\
\text { funding }\end{array}$} & $\begin{array}{l}\text { Should not be limited to countries } \\
\text { where reductions in deforestation } \\
\text { emissions are cheapest, nor countries } \\
\text { with greater monitoring capacities } \\
\text { and associated lower risks of } \\
\text { impermanence. }\end{array}$ & Greenpeace (Mar. 08) \\
\hline & $\begin{array}{l}\text { Special funds targeted for capacity } \\
\text { building in developing countries. }\end{array}$ & Mexico (Aug. 08) \\
\hline
\end{tabular}




\begin{tabular}{|c|c|c|}
\hline Issues & Opinions & Supported by \\
\hline \multicolumn{3}{|c|}{ Funding (continued) } \\
\hline \multirow{2}{*}{$\begin{array}{l}\text { Source of funding: } \\
\text { Annex I vs. Not } \\
\text { only Annex I }\end{array}$} & $\begin{array}{l}\text { Source of financial resources for REDD } \\
\text { from Annex I countries. }\end{array}$ & Brazil (Mar. 07) \\
\hline & $\begin{array}{l}\text { No presumption that the source of } \\
\text { financial resources to address REDD is } \\
\text { limited to Annex } 1 \text { countries. }\end{array}$ & $\begin{array}{l}\text { New Zealand (Apr. 08); } \\
\text { Mexico (Jun. 08) }\end{array}$ \\
\hline \multirow[t]{4}{*}{$\begin{array}{l}\text { Fungibility of } \\
\text { emission reduction } \\
\text { credits }\end{array}$} & $\begin{array}{l}\text { Fungibility. REDD produces tradable } \\
\text { credits for Annex } 1 \text { country reductions. } \\
\text { Fungibility advocates want REDD } \\
\text { supported by a large market and fear } \\
\text { that REDD funding would fall short, } \\
\text { as with CDM, if REDD credits are not } \\
\text { tradable in the main carbon markets. }\end{array}$ & $\begin{array}{l}\text { Chile (Aug. 07), } \\
\text { Paraguay, Argentina, } \\
\text { Honduras, Panama, } \\
\text { Peru (Apr. o8); } \\
\text { Colombia (Apr. 08); } \\
\text { CfRN (Sept. 07, Apr. 08); } \\
\text { CISDL and GPPI (Feb. } \\
\text { 07); Mexico (aug. 08) }\end{array}$ \\
\hline & $\begin{array}{l}\text { Not fungible. Non-fungibility } \\
\text { proponents fear large volumes of } \\
\text { cheap credits would destabilise } \\
\text { the carbon compliance market and } \\
\text { would reduce prices, and/or industrial } \\
\text { countries would take fewer actions to } \\
\text { reduce their emissions from fossil fuels } \\
\text { and industries. }\end{array}$ & $\begin{array}{l}\text { Brazil (Mar. 07); } \\
\text { Greenpeace (Dec. 07) }\end{array}$ \\
\hline & $\begin{array}{l}\text { Limited fungibility. For instance, to } \\
\text { prevent any risk of flooding markets, } \\
\text { specific limits or caps could be } \\
\text { imposed on the volume of eligible } \\
\text { credits. }\end{array}$ & $\begin{array}{l}\text { BioCarbon (World } \\
\text { Bank) (Aug. 08) }\end{array}$ \\
\hline & $\begin{array}{l}\text { Not fungible in the short- and } \\
\text { medium-term (before } 2012 \text { or } 2020 \text { ). } \\
\text { Future fungibility is conditional on } \\
\text { Annex I countries committing to } \\
\text { higher reduction targets. }\end{array}$ & $\begin{array}{l}\text { CCAP (Aug. 07) not } \\
\text { fungible until 2012; } \\
\text { EU (Apr. 08); EU ( Jul. } \\
\text { 08); EU (Oct. 08) not } \\
\text { fungible until } 2020\end{array}$ \\
\hline \multicolumn{3}{|c|}{ Baseline/reference level } \\
\hline Basis for funding & $\begin{array}{l}\text { Funding based on the specific } \\
\text { financial needs of REDD countries } \\
\text { and/or national circumstances. }\end{array}$ & $\begin{array}{l}\text { PNG (Apr. 08); EU } \\
\text { (Jul. 08); Paraguay, } \\
\text { Argentina, Honduras, } \\
\text { Panama, Peru (Apr. 08) }\end{array}$ \\
\hline
\end{tabular}




\begin{tabular}{|c|c|c|}
\hline Issues & Opinions & Supported by \\
\hline \multicolumn{3}{|c|}{ Baseline/reference level (continued) } \\
\hline \multirow[t]{9}{*}{$\begin{array}{l}\text { Method to set the } \\
\text { baseline }\end{array}$} & $\begin{array}{l}\text { Recommend using historical } \\
\text { deforestation data. }\end{array}$ & $\begin{array}{l}\text { Bali Action Plan (Dec. } \\
\text { 07); Costa Rica (Apr. } \\
\text { 08); FAO, UNDP, UNEP } \\
\text { (Apr. 08); CCAP (Aug. } \\
\text { 07); Brazil (Mar. 07); } \\
\text { Indonesia (Apr. 08); } \\
\text { India (Apr. 08); New } \\
\text { Zealand (Apr. 08); } \\
\text { PNG (Apr. 08); EU } \\
\text { (Apr. 08); Greenpeace } \\
\text { (Mar. 08); CfRN } \\
\text { (Sept. 07); Paraguay, } \\
\text { Argentina, Honduras, } \\
\text { Panama, Peru (Apr. 08) } \\
\text { (continuation of their } \\
\text { nested approach put } \\
\text { forward by Paraguay } \\
\text { et al. 07); EU (Jul. 08); } \\
\text { Norway (Sept. 08) }\end{array}$ \\
\hline & $\begin{array}{l}\text { Separate baselines for deforestation } \\
\text { (hectares forest lost/year), and forest } \\
\text { degradation (tonnes carbon/ha/year). }\end{array}$ & Nepal (Apr. 08) \\
\hline & $\begin{array}{l}\text { Set aside forest to serve as baseline in } \\
\text { stock-based approach. }\end{array}$ & $\begin{array}{l}\text { CISDL and GPPI (Feb. } \\
07)\end{array}$ \\
\hline & $\begin{array}{l}\text { Recommend using projected trends/ } \\
\text { extrapolation of historical trends into } \\
\text { the future. }\end{array}$ & $\begin{array}{l}\text { Indonesia (Apr. 08); } \\
\text { CISDL and GPPI (Feb. } \\
\text { 07); COMIFAC (Apr. 08); } \\
\text { Colombia (Apr. 08) }\end{array}$ \\
\hline & $\begin{array}{l}\text { National mechanisms will allow more } \\
\text { accurate baseline development. }\end{array}$ & New Zealand (Apr. 08) \\
\hline & $\begin{array}{l}\text { Develop a system of nested baselines } \\
\text { for different areas within a country, } \\
\text { where the total emissions and sinks } \\
\text { sum up to the national baseline level. }\end{array}$ & Nepal (Apr. 08) \\
\hline & $\begin{array}{l}\text { Further studies are needed to make } \\
\text { recommendations. }\end{array}$ & USA (Apr. 08) \\
\hline & $\begin{array}{l}\text { Historical baselines are not an accurate } \\
\text { indication of future deforestation } \\
\text { pressures for countries that currently } \\
\text { have low deforestation rates. }\end{array}$ & Norway (Sept. 08) \\
\hline & $\begin{array}{l}\text { Use a discount factor to resolve } \\
\text { baseline uncertainties or take national } \\
\text { circumstances into account. }\end{array}$ & $\begin{array}{l}\text { Greenpeace (Mar. 08); } \\
\text { PNG (Apr. 08) }\end{array}$ \\
\hline
\end{tabular}




\begin{tabular}{|c|c|c|}
\hline Issues & Opinions & Supported by \\
\hline \multicolumn{3}{|c|}{ Leakage } \\
\hline \multirow[t]{6}{*}{$\begin{array}{l}\text { Dealing with } \\
\text { leakage }\end{array}$} & $\begin{array}{l}\text { Suggest using national approach to } \\
\text { account for leakage. }\end{array}$ & $\begin{array}{l}\text { CISDL and GPPI (Feb. } \\
\text { 07); CfRN (Sept. 07); } \\
\text { CCAP (Aug. 07); New } \\
\text { Zealand (Apr. 08); FAO, } \\
\text { UNDP, UNEP (Apr. 08); } \\
\text { Indonesia (Apr. 08); USA } \\
\text { (Apr. 08) }\end{array}$ \\
\hline & $\begin{array}{l}\text { Suggest other technical mechanisms } \\
\text { to address leakage, e.g. reserve } \\
\text { accounts, insurance, leakage belt. }\end{array}$ & $\begin{array}{l}\text { Costa Rica (Apr. 08); } \\
\text { Greenpeace (Mar. 08); } \\
\text { Colombia (Apr. 08) }\end{array}$ \\
\hline & $\begin{array}{l}\text { Suggest regulatory mechanisms, such } \\
\text { as removing institutional barriers. }\end{array}$ & Indonesia (Apr. 08) \\
\hline & $\begin{array}{l}\text { Routine monitoring to check for } \\
\text { degradation leakage. }\end{array}$ & Nepal (Apr 08) \\
\hline & $\begin{array}{l}\text { Acknowledge importance of } \\
\text { addressing leakage, but no specific } \\
\text { recommendations. }\end{array}$ & $\begin{array}{l}\text { Bali Action Plan (Dec. } \\
\text { 07); CBD (May 08); USA } \\
\text { (Apr. 08); Colombia } \\
\text { (Apr. 08) }\end{array}$ \\
\hline & $\begin{array}{l}\text { Need to address international leakage } \\
\text { since, even with national accounting, } \\
\text { the problem still exists. }\end{array}$ & $\begin{array}{l}\text { Colombia (Apr. 08); } \\
\text { CCAP (Aug. 07); USA } \\
\text { (Apr. 08); Norway (Sept. } \\
\text { 08) }\end{array}$ \\
\hline \multirow[t]{2}{*}{$\begin{array}{l}\text { Use of adjustment } \\
\text { factors }\end{array}$} & $\begin{array}{l}\text { Use adjustment factors to take leakage } \\
\text { into account. }\end{array}$ & $\begin{array}{l}\text { Greenpeace (Mar. 08); } \\
\text { BioCarbon (World } \\
\text { Bank) (Aug. 08) }\end{array}$ \\
\hline & $\begin{array}{l}\text { Should not use adjustment factors to } \\
\text { take leakage into account. }\end{array}$ & New Zealand (Apr. 08) \\
\hline \multicolumn{3}{|c|}{ Permanence and liability } \\
\hline \multirow[t]{4}{*}{$\begin{array}{l}\text { Recommendations } \\
\text { for non- } \\
\text { permanence }\end{array}$} & $\begin{array}{l}\text { Use reserve accounts to address } \\
\text { permanence. A proportion of the } \\
\text { projected emission reductions are } \\
\text { kept in reserve to cover this risk of } \\
\text { non-permanence. }\end{array}$ & $\begin{array}{l}\text { Costa Rica (Apr. 08); } \\
\text { CISDL and GPPI } \\
\text { (Feb. 07); Paraguay, } \\
\text { Argentina, Honduras, } \\
\text { Panama, Peru (Apr. 08) }\end{array}$ \\
\hline & $\begin{array}{l}\text { If emissions occur in the current } \\
\text { period, carbon credits can be taken } \\
\text { out in a future period. }\end{array}$ & $\begin{array}{l}\text { Brazil (Mar. 07); PNG } \\
\text { (Apr. 08) }\end{array}$ \\
\hline & $\begin{array}{l}\text { Creation of protected areas as a way to } \\
\text { ensure permanence. }\end{array}$ & $\begin{array}{l}\text { CBD (May 08); Costa } \\
\text { Rica (Apr. 08) }\end{array}$ \\
\hline & $\begin{array}{l}\text { Use discount factor to take into } \\
\text { account non-permanence of REDD } \\
\text { credits. }\end{array}$ & Greenpeace (Mar. 08) \\
\hline
\end{tabular}




\begin{tabular}{|c|c|c|}
\hline Issues & Opinions & Supported by \\
\hline \multicolumn{3}{|c|}{ Permanence and liability (continued) } \\
\hline \multirow{3}{*}{$\begin{array}{l}\text { Recommendations } \\
\text { for non- } \\
\text { permanence } \\
\text { (continued) }\end{array}$} & $\begin{array}{l}\text { Use temporary credits that are } \\
\text { renewable. }\end{array}$ & $\begin{array}{l}\text { CISDL and GPPI (Feb. } \\
\text { 07); BioCarbon (World } \\
\text { Bank) (Aug. 08) }\end{array}$ \\
\hline & $\begin{array}{l}\text { Set up an insurance scheme to } \\
\text { manage risk of carbon emissions. }\end{array}$ & $\begin{array}{l}\text { BioCarbon (World } \\
\text { Bank) (Aug. 08); CfRN } \\
\text { (Sept. 07) }\end{array}$ \\
\hline & $\begin{array}{l}\text { Countries should not be penalised } \\
\text { if deforestation is caused by natural } \\
\text { disasters. }\end{array}$ & Costa Rica (Apr. 08) \\
\hline \multirow[t]{2}{*}{ Issue of liability } & $\begin{array}{l}\text { Developing countries should not } \\
\text { be penalised if they do not meet } \\
\text { emissions reductions targets, but } \\
\text { receive incentives if they do. }\end{array}$ & CCAP (Aug. 07) \\
\hline & $\begin{array}{l}\text { Countries are liable for compliance } \\
\text { failure. }\end{array}$ & CfRN (Sept. 07) \\
\hline \multicolumn{3}{|c|}{ Monitoring, reporting and verification (MRV) } \\
\hline \multirow[t]{4}{*}{$\begin{array}{l}\text { Monitoring DD } \\
\text { emissions }\end{array}$} & $\begin{array}{l}\text { Carbon stocks estimated for each } \\
\text { biome associated with remote sensing } \\
\text { measurements. }\end{array}$ & Brazil (Mar. 07) \\
\hline & Remote sensing with ground truthing. & $\begin{array}{l}\text { EU (Apr. 08); Nepal (Apr. } \\
\text { 08) }\end{array}$ \\
\hline & $\begin{array}{l}\text { Need more accurate measurement } \\
\text { methods and research. Carbon stocks } \\
\text { in different ecosystems are poorly } \\
\text { known. Inventory tools and methods } \\
\text { need a lot of investment. Need } \\
\text { ecosystem specific models. }\end{array}$ & $\begin{array}{l}\text { Chile (Aug. 07), } \\
\text { Paraguay, Argentina, } \\
\text { Honduras, Panama, } \\
\text { Peru (Apr. 08); USA (Apr. } \\
\text { 08) }\end{array}$ \\
\hline & $\begin{array}{l}\text { Carbon stock approach offers } \\
\text { opportunities for countries with low } \\
\text { deforestation rates. 1) A country } \\
\text { estimates its aboveground carbon } \\
\text { stock; } 2 \text { ) Non-tradable 'Carbon Stock } \\
\text { Units' are issued equal to (1); 3) A } \\
\text { protected reserve is established, } \\
\text { covering all forest that is not at threat } \\
\text { from deforestation; } 4 \text { ) A conservation } \\
\text { project for a forest area outside } \\
\text { the reserve produces credits; 5) On } \\
\text { approval of such a project, a 'Carbon } \\
\text { Stock Mechanism' allows trading of } \\
\text { credits produced by this project; and } \\
6) \text { Credits are temporary to address } \\
\text { the permanence issue. }\end{array}$ & $\begin{array}{l}\text { CISDL and GPPI (Feb. } \\
\text { 07); Sri Lanka (Apr. 08); } \\
\text { COMIFAC (Mar. 07) }\end{array}$ \\
\hline
\end{tabular}




\begin{tabular}{|c|c|c|}
\hline Issues & Opinions & Supported by \\
\hline \multicolumn{3}{|c|}{ Monitoring, reporting and verification (MRV) (continued) } \\
\hline Incentives for MRV & $\begin{array}{l}\text { Recognise the need for up-front } \\
\text { funding and incentives for MRV and } \\
\text { capacity building. }\end{array}$ & $\begin{array}{l}\text { Brazil (Mar. 07); } \\
\text { COMIFAC (Apr. 08); } \\
\text { Costa Rica (Apr. 08); } \\
\text { CfRN (Sep. 07); PNG } \\
\text { (Apr. 08); Norway (Sept. } \\
\text { 08) }\end{array}$ \\
\hline \multirow{2}{*}{$\begin{array}{l}\text { Monitoring } \\
\text { approaches } \\
\text { Full vs. partial } \\
\text { accounting }\end{array}$} & $\begin{array}{l}\text { Full accounting: The entire country } \\
\text { forest area is monitored - 'wall-to-wall } \\
\text { mapping'. }\end{array}$ & $\begin{array}{l}\text { Brazil (Mar. 07); New } \\
\text { Zealand (Apr. 08) }\end{array}$ \\
\hline & $\begin{array}{l}\text { Partial accounting. Sampling } \\
\text { monitoring (systematic or stratified } \\
\text { sampling) or project level sampling. }\end{array}$ & $\begin{array}{l}\text { Indonesia (Apr. } \\
\text { 08); Colombia (Apr. } \\
\text { 08); COMIFAC (Apr. } \\
\text { 08); Chile (Aug. 07), } \\
\text { Paraguay, Argentina, } \\
\text { Honduras, Panama, } \\
\text { Peru (Apr. 08) }\end{array}$ \\
\hline $\begin{array}{l}\text { Estimating } \\
\text { effectiveness in } \\
\text { terms of emission } \\
\text { reductions }\end{array}$ & $\begin{array}{l}\text { The effectiveness of the adopted } \\
\text { REDD activities should be assessed } \\
\text { in terms of the amount of emissions } \\
\text { reductions obtained by the host } \\
\text { country, in order to avoid any perverse } \\
\text { incentives. }\end{array}$ & Costa Rica (Apr. 08) \\
\hline
\end{tabular}

Effectiveness should take into account EU (Apr. 08) the effects on communities and biodiversity.

\begin{tabular}{lll}
\hline $\begin{array}{l}\text { MRV transparency } \\
\text { and role of related } \\
\text { institutions }\end{array}$ & $\begin{array}{l}\text { Data should be public, for instance } \\
\text { they could be published for COPs and } \\
\text { on the web. }\end{array}$ & $\begin{array}{l}\text { Brazil (Feb. 07); } \\
\text { Colombia (Apr. 08); } \\
\text { Chile (Aug. 07); } \\
\text { Paraguay, Argentina, } \\
\text { Honduras, Panama, } \\
\text { Peru (Apr. 08) }\end{array}$ \\
\cline { 2 - 3 } & & $\begin{array}{l}\text { Brazil (Mar. 07); CCAP } \\
\text { (Aug. 07) }\end{array}$ \\
& Annual report on inventories. & Chile (Aug. 07); \\
& Paraguay, Argentina, \\
International bodies within IPPCC/ & Honduras, Panama, \\
UNFCCC define the MRV methods. & Peru (Apr. 08); Brazil \\
& (Feb. 07); Canada (Apr. \\
& 08); Colombia (Apr. 08); \\
& Costa Rica (Apr. 08); \\
CfRN (Sept. 07); SBSTA \\
for FAO, UNDP, UNEP \\
(Apr. 08); Indonesia \\
(Apr. 08); PNG (Apr. 08); \\
Norway (Sept. 08)
\end{tabular}




\begin{tabular}{|c|c|c|}
\hline Issues & Opinions & Supported by \\
\hline \multicolumn{3}{|c|}{ Monitoring, reporting and verification (MRV) (continued) } \\
\hline \multirow[t]{2}{*}{$\begin{array}{l}\text { MRV transparency } \\
\text { and role of related } \\
\text { institutions } \\
\text { (continued) }\end{array}$} & $\begin{array}{l}\text { Independent and accredited } \\
\text { verification system is needed to } \\
\text { determine reference emission levels, } \\
\text { actual emission reductions and } \\
\text { leakage }\end{array}$ & $\begin{array}{l}\text { Colombia (Apr. 08); } \\
\text { Chile (Aug. 07); } \\
\text { Paraguay, Argentina, } \\
\text { Honduras, Panama, } \\
\text { Peru (Apr. 08); Norway } \\
\text { (Sept. 08) }\end{array}$ \\
\hline & $\begin{array}{l}\text { Carbon monitoring results should not } \\
\text { need to be verified by institutions or } \\
\text { experts outside the country because } \\
\text { they should be supported by national } \\
\text { institutional mechanisms that are } \\
\text { appropriate to national and local } \\
\text { government systems. }\end{array}$ & Indonesia (Apr. 08) \\
\hline $\begin{array}{l}\text { MRV mechanism } \\
\text { Risks regarding } \\
\text { MRV }\end{array}$ & $\begin{array}{l}\text { To avoid risks, emission reductions } \\
\text { should be discounted as a proxy for } \\
\text { managing uncertainties on estimating } \\
\text { emissions, baselines and permanence. }\end{array}$ & Greenpeace (Mar. 08) \\
\hline \multicolumn{3}{|c|}{ Degradation } \\
\hline \multirow[t]{5}{*}{$\begin{array}{l}\text { Include or exclude } \\
\text { REDD }\end{array}$} & $\begin{array}{l}\text { Include both deforestation and forest } \\
\text { degradation. }\end{array}$ & $\begin{array}{l}\text { Bali Action Plan (Dec. } \\
\text { 07); Norway (Sept. } \\
\text { 08); Australia (Apr. 08); } \\
\text { CCAP (Aug. 07); CISDL } \\
\text { and GPPI (Feb. 07); } \\
\text { Costa Rica (Apr. 08); } \\
\text { CfRN (Sept. 07); EU (Apr. } \\
\text { 08); Japan (Aug. 08); } \\
\text { Nepal (Apr. 08); USA } \\
\text { (Apr. 08) }\end{array}$ \\
\hline & $\begin{array}{l}\text { Support inclusion of degradation, } \\
\text { but not systematically. Each activity } \\
\text { should decide if it is cost effective to } \\
\text { include forest degradation. }\end{array}$ & Colombia (Apr. 08) \\
\hline & $\begin{array}{l}\text { Should include forest degradation, but } \\
\text { be wary of the methodological issues. }\end{array}$ & Greenpeace (Mar. 08) \\
\hline & $\begin{array}{l}\text { Against including forest degradation, } \\
\text { as it risks jeopardising the REDD } \\
\text { process. Some methodological } \\
\text { issues for measuring degradation are } \\
\text { unsolved. }\end{array}$ & Brazil (Mar. 07) \\
\hline & $\begin{array}{l}\text { REDD first, REDD where ever we can, } \\
\text { or later if feasible. Countries which are } \\
\text { not ready to meet methodological } \\
\text { requirements for measuring forest } \\
\text { degradation should be allowed } \\
\text { to receive incentives for reducing } \\
\text { deforestation. }\end{array}$ & $\begin{array}{l}\text { Canada (Apr. 08); EU } \\
\text { (Apr. 08); Greenpeace } \\
\text { (Mar. 08) }\end{array}$ \\
\hline
\end{tabular}




\begin{tabular}{|c|c|c|}
\hline Issues & Opinions & Supported by \\
\hline \multicolumn{3}{|c|}{ Degradation (continued) } \\
\hline $\begin{array}{l}\text { REDD or RED } \\
\text { (include or exclude } \\
\text { degradation) } \\
\text { (continued) }\end{array}$ & $\begin{array}{l}\text { The methodological requirements } \\
\text { for measuring degradation can be } \\
\text { overcome and we should include } \\
\text { forest degradation without delay. }\end{array}$ & Costa Rica (Apr. 08) \\
\hline \multirow[t]{2}{*}{$\begin{array}{l}\text { Monitoring } \\
\text { degradation }\end{array}$} & $\begin{array}{l}\text { There are still a number of monitoring } \\
\text { issues. Research has not shown that } \\
\text { incremental changes associated with } \\
\text { forest degradation can be captured } \\
\text { accurately solely through remote } \\
\text { sensing. In order to capture the net } \\
\text { flux of such activities repeated survey } \\
\text { sampling is required. }\end{array}$ & USA (Apr. 08) \\
\hline & $\begin{array}{l}\text { Suggest indirect approach to monitor } \\
\text { forest degradation (areas of intact } \\
\text { and non-intact forests between two } \\
\text { observations periods). Estimation } \\
\text { and demonstration of reduction } \\
\text { in emissions from degradation by } \\
\text { methods such as inventories or } \\
\text { assessing canopy openness by remote } \\
\text { sensing with ground truthing. }\end{array}$ & $\begin{array}{l}\text { EU (Apr. 08); Colombia } \\
\text { (Apr. 08); Nepal (Apr. } \\
\text { 08) }\end{array}$ \\
\hline \multirow[t]{5}{*}{$\begin{array}{l}\text { Implications } \\
\text { of including } \\
\text { degradation }\end{array}$} & $\begin{array}{l}\text { Measuring degradation requires } \\
\text { additional sampling and monitoring } \\
\text { on the ground, and more funding for } \\
\text { capacity building and implementation. }\end{array}$ & $\begin{array}{l}\text { CCAP (Aug. 07); Norway } \\
\text { (Sept. 08) }\end{array}$ \\
\hline & $\begin{array}{l}\text { Reducing degradation will provide } \\
\text { a number of co-benefits, such as } \\
\text { biodiversity. }\end{array}$ & $\begin{array}{l}\text { CISDL and GPPI (Feb. } \\
07 \text { ) }\end{array}$ \\
\hline & $\begin{array}{l}\text { Deforestation and forest degradation } \\
\text { definitions need to be tackled. }\end{array}$ & $\begin{array}{l}\text { Colombia (Apr. 08); } \\
\text { COMIFAC (Apr. 08) }\end{array}$ \\
\hline & $\begin{array}{l}\text { Integrated management of } \\
\text { peatlands is required. The large- } \\
\text { scale degradation of peatlands, } \\
\text { including forested peatlands, has } \\
\text { major implications for climate change, } \\
\text { biodiversity and people. }\end{array}$ & CBD (May 08) \\
\hline & \multicolumn{2}{|l|}{ REDD co-benefits } \\
\hline $\begin{array}{l}\text { Various positions } \\
\text { on REDD co- } \\
\text { benefits }\end{array}$ & $\begin{array}{l}\text { Environmental conservation and } \\
\text { biodiversity co-benefits are essential } \\
\text { for effectiveness. }\end{array}$ & $\begin{array}{l}\text { Bali Action Plan (Dec. } \\
\text { 07); CBD (May 08); } \\
\text { FAO-UNDP-UNEP, } \\
\text { Greenpeace (Mar. 08); } \\
\text { BioCarbon (World } \\
\text { Bank) (Aug. 08); Mexico } \\
\text { (Aug. 08); EU (Jul. 08) }\end{array}$ \\
\hline
\end{tabular}




\begin{tabular}{|c|c|c|}
\hline Issues & Opinions & Supported by \\
\hline \multicolumn{3}{|c|}{ REDD co-benefits (continued) } \\
\hline \multirow[t]{3}{*}{$\begin{array}{l}\text { Various positions } \\
\text { on REDD co- } \\
\text { benefits } \\
\text { (continued) }\end{array}$} & $\begin{array}{l}\text { Poverty alleviation/sustainable } \\
\text { development goals should be } \\
\text { included in a REDD scheme. }\end{array}$ & $\begin{array}{l}\text { FAO-UNDP-UNEP, } \\
\text { BioCarbon (World } \\
\text { Bank) (Aug. 08); Mexico } \\
\text { (Aug. 08) }\end{array}$ \\
\hline & $\begin{array}{l}\text { Rights of minority groups, forest- } \\
\text { dependent peoples, and indigenous } \\
\text { groups should be protected. }\end{array}$ & $\begin{array}{l}\text { FAO-UNDP-UNEP, } \\
\text { Greenpeace (Mar. 08); } \\
\text { EU (Jul. 08); Norway } \\
\text { (Sept. 08) }\end{array}$ \\
\hline & $\begin{array}{l}\text { Co-benefits should not influence } \\
\text { REDD implementation. }\end{array}$ & PNG (Apr. 08) \\
\hline
\end{tabular}





\section{Abbreviations}

$3 \mathrm{E}$

$\mathrm{A} / \mathrm{R}$

AAU

AD

AFOLU

ARD

BAU

CAT

CBD

CCAP

$\mathrm{CDM}$

CER

CfRN

CIFOR

CISDL

$\mathrm{CO} 2 \mathrm{e}$

COP

CSR

DD

DNA

ETS

EU

FPIC

GEF

GHG

GOFC - GOLD GPG
Effective, Efficient, and Equitable

Afforestation/Reforestation

Assigned Amount Unit

Avoided Deforestation

Agriculture, Forestry and other Land Use

Afforestation, Reforestation, and Deforestation

Business as Usual

Cap and Trade

Convention on Biological Diversity

Center for Clean Air Policy

Clean Development Mechanism

Certified Emission Reductions

Coalition for Rainforest Nations

Center for International Forestry Research

Centre for International Sustainable Development Law

Carbon Dioxide Equivalent

Conference of the Parties

Corporate Social Responsibility

Deforestation and Forest Degradation

Designated National Authority

Emissions Trading Scheme

European Union

Free, Prior, and Informed Consent

Global Environmental Facility

Green House Gas

Global Observation of Forest and Land Cover Dynamics

Good Practice Guide 
GPPI Global Public Policy Institute

ha

hectare

HWP

Harvested Wood Products

ICDP

Integrated Conservation and Development Project

IPCC

Intergovernmental Panel on Climate Change

JI

Joint Implementation

LDC

Less Developed Countries

LULUCF

Land Use, Land Use Change, Forestry

MAI

Mean annual increment

MRV

Monitoring, Reporting, and Verification

ODA

Official Development Assistance

PAM

Policies and Measures

PES

Payments for Environmental Services

PNG

Papua New Guinea

REDD

Reducing Emissions from Deforestation and Degradation

RIL Reduced Impact Logging

SBSTA

Subsidiary Body for Scientific and Technological Advice

TDERM Tropical Deforestation Emission Reduction Mechanism

$\mathrm{tC}$ Metric tonnes of carbon

$\operatorname{TgC}$ Teragrams of carbon $=$ Million metric tonnes of carbon

UNCCD United Nations Convention to Combat Desertification

UNFF United Nations Forum on Forests

UNFCCC United Nations Framework Convention on Climate Change

VER Verified Emission Reduction 


\section{Alossary}

\section{E Criteria}

The 3E criteria (Effectiveness, Efficiency and Equity) were first used in the Stern Report (see Stern Report entry below) to evaluate global greenhouse gas (GHG) reductions schemes. These criteria are used in this book to evaluate different options for a REDD global architecture (see end of Chapter 2 for further explanation).

\section{Additionality}

Refers to the nature of projects under the Kyoto Protocol. Projects must demonstrate 'additionality' - real, measurable and long-term benefits in reducing or preventing carbon emissions that would have occurred without the project. Alternatively, additionality in crediting systems means payments for reducing emissions to a level below the businessas-usual scenario (see entry).

\section{Afforestation}

Afforestation is defined under the Kyoto Protocol as the direct humaninduced conversion of non-forest land to permanent forested land (for a period of at least 50 years).

\section{AFOLU}

Acronym for Agriculture, Forestry and Other Land Uses. Recommended by IPCC Guidelines (2006) as a new term covering LULUCF (Land Use, Land Use Change and Forestry) and agriculture.

\section{Annex I and Non-Annex I Countries}

Under the UN Framework Convention on Climate Change(UNFCCC), nations fall into two categories: developed countries (referred to as Annex I countries) and developing countries (referred to as NonAnnex I countries). In accordance with the principle of common but differentiated responsibilities, Annex I countries have higher levels of commitments related to policy enactment and reporting, and most of them have emissions reductions commitments in the Kyoto Protocol. 


\section{Bali Action Plan}

The Bali Action Plan refers to Decision 1/CP.13 that sets out the framework for international negotiations on a '...comprehensive process to enable the full, effective and sustained implementation of the Convention through long-term cooperative action, now, up to and beyond 2012'. The Action Plan includes provisions for 'Policy approaches and positive incentives on issues relating to reducing emissions from deforestation and forest degradation in developing countries; and the role of conservation, sustainable management of forests and enhancement of forest carbon stocks in developing countries'.

\section{Baseline}

Baseline or reference line can refer to three concepts (see Chapter 6): (i) the historical baseline, that is, the rate of deforestation and forest degradation (DD) and the resulting $\mathrm{CO}_{2}$ emissions over the past $\mathrm{x}$ years; (ii) the projected DD under a business-as-usual (BAU) scenario. A BAU baseline is the benchmark for judging the impact of the REDD measures and ensuring additionality; and (iii) the crediting baseline, or reference level, is a benchmark for rewarding the country (or project) if emissions are below that level.

\section{BioCarbon Fund}

A public/private fund administered by the World Bank to demonstrate projects that sequester or conserve carbon in forest and agroecosystems.

\section{Biomass}

The total dry mass of living organic matter.

\section{Business-as-Usual (BAU)}

A policy neutral reference to future emissions, that is, projections of future emission levels without the REDD activity.

\section{Canopy cover}

See 'crown cover'.

\section{Carbon Markets}

Any market in which carbon emissions trading, usually in the form of carbon credits, takes place. Markets consist of voluntary markets (where emissions reductions targets are not regulated) and compliance markets (where carbon credits are traded to meet regulated emissions reductions targets). The largest carbon market at the moment is the EU's Emissions Trading System (ETS).

\section{Carbon pool}

A reservoir or stock which has the capacity to accumulate or release carbon. In forests there are five main carbon pools aboveground biomass, belowground biomass, dead wood, litter and soil organic matter. 


\section{Carbon rights}

Carbon rights refer to the claims on the benefit streams from carbon pools, for example, the benefit from a specific parcel of forest. Where a market exists for GHG emissions reductions carbon rights may have a financial value. Carbon rights may also define the management responsibilities associated with a specific area of forest. Issues concerning carbon rights include how the rights are defined, how they work in places where land ownership is unclear, and whether legal institutions are strong enough to protect the rights.

\section{Carbon sequestration}

The removal of carbon from the atmosphere and long-term storage in sinks, such as ocean or terrestrial ecosystems, through physical or biological processes, such as photosynthesis.

\section{Carbon sink}

A pool (reservoir) that absorbs or takes up carbon released from other components of the carbon cycle.

\section{Carbon stocks}

The quantity of carbon contained in a carbon pool (see 'carbon pool').

\section{Certified Emission Reduction (CER)}

The technical term for the output of CDM projects. A CER is a unit of GHG reductions that has been generated and certified under the provisions of Article 12 of the Kyoto Protocol, the Clean Development Mechanism. One CER equals one tonne of carbon. Two special types of CERs can be issued for net emission removals from afforestation and reforestation CDM projects: (i) temporary certified emission reduction (tCERs); and (ii) long-term certified emission reductions (lCERs)

\section{Clean Development Mechanism (CDM)}

A mechanism under the Kyoto Protocol designed to help developed (Annex I) countries to meet their emissions reduction targets. The mechanism allows for Annex I countries that finance and implement projects that reduce emissions in developing (Non-Annex I) countries to get credits that can be used to fulfill their own emissions reduction targets. The CDM aims not only to reduce emissions or increase sinks, but also to contribute to sustainable development in developing countries.

\section{Coalition for Rainforest Nations (CfRN)}

A collaboration between developing nations with rainforests to reconcile forest stewardship with economic development. As of November 2008, participants included 41 countries in Asia, Africa, the Americas and Oceania. Sometimes the Coalition acts as a single group in UNFCCC negotiations. It is behind a number of REDD submissions. 


\section{Co-benefits}

Benefits arising from REDD schemes (other than reducing GHG emissions), such as alleviating poverty, protecting the environment, enhancing biodiversity, improving forest governance and protecting human rights.

\section{Conference of the Parties (COP)}

The governing body of the UNFCCC, which meets once a year.

\section{Crown cover}

The percentage of the surface of an ecosystem that is under the tree canopy. Also referred to as 'canopy cover' or just 'tree cover'.

\section{Deforestation}

Most definitions describe deforestation as the long-term or permanent conversion of land from forest to non-forest. In an annex to a decision made by the UNFCCC Conference of Parties (COP), which serves as a meeting of the Parties to the Kyoto Protocol, deforestation is defined as 'the direct human-induced conversion of forested land to non-forested land'. The FAO defines deforestation as 'the conversion of forest to another land use or the long-term reduction of the tree canopy cover below the minimum 10\% threshold'. Definitions also stipulate minimum tree heights (FAO: $5 \mathrm{~m}$ in situ) and minimum areas (FAO: $0.5 \mathrm{ha}$ ), and that agriculture must not be the dominant use. But the definitions of minimum canopy cover, height and area vary from country to country.

\section{Degradation}

Changes within the forest which negatively affect the structure or function of the forest stand or site, and thereby lower the capacity of the forest to supply products and/or services. In the context of a REDD mechanism, forest degradation results in the net loss of carbon from the ecosystem. One way to measure degradation is to measure the decrease in the carbon stock per area unit (e.g. hectare).

\section{Forest rent}

Forest rent can be defined as the net profit from a parcel of forest land, that is, the difference between the gross income derived from the products and services generated and the opportunity costs of the inputs used.

\section{Forest transition}

Describes the changes in forest cover over time as a sequence of four stages. These are (i) initially high forest cover and low deforestation; (ii) accelerating and high deforestation; (iii) slow-down of deforestation and stabilisation of forest cover; and (vi) a period of reforestation. 


\section{Fungibility (of REDD credits)}

The degree of exchangeability between REDD credits and carbon credits in carbon markets. When REDD credits are fully fungible, they can be sold without restriction and used for purposes such as meeting emission reductions targets in countries that have committed to such targets.

\section{Hot air}

Emissions reductions that are not truly additional (see 'additionality'). To illustrate, consider the situation in former Soviet Union and Eastern Europe. Economic decline in the 1990s led to a sharp decrease in GHG emissions. Levels were lower than those in 1990, which was the crediting baseline level. Under the rules of the Kyoto Protocol, these countries were eligible to sell the difference as credits, despite the fact that credits came from emissions reductions that would have occurred anyway (i.e. not additional).

\section{Input-based payments}

Payments that are made conditional on inputs which are assumed to produce emissions reductions, but where the outcome cannot be measured directly (or is very costly to measure). Input-based payment schemes are often referred to as 'policies and measures' (PAMs).

\section{Joint Implementation (JI)}

A mechanism under the Kyoto Protocol (alongside CDM) designed to help Annex I countries to meet their emission reduction targets by investing in emissions reduction projects in other Developed countries as an alternative to reducing emissions domestically. Unlike the CDM, JI emissions reductions take place in countries that have GHG emission targets.

\section{Kyoto Protocol}

An agreement made in 1997 under the United Nations Framework Convention on Climate Change (UNFCCC). Annex I countries that ratify this Protocol (categorized as Annex I countries) commit to reducing their emissions of carbon dioxide and five other GHGs. The Kyoto Protocol now covers more than 170 countries globally, but only $60 \%$ in terms of global GHG emissions. As of December 2007, the US and Kazakhstan are the only signatory nations not to have ratified the Protocol. The first commitment period of the Kyoto Protocol ends in 2012, and international talks began in May 2007 on the next commitment period. 


\section{Leakage}

In the context of climate change, carbon leakage is the result of interventions to reduce emissions in one geographical area (subnational or national) that lead to an increase in emissions in another area. For example, if curbing the encroachment of agriculture into forests in one region results in conversion of forests to agriculture in another region this is considered to be 'leakage'. In the context of REDD, leakage is also referred to as 'emissions displacement'.

\section{Liability}

It is the obligation of the REDD implementing project or country to ensure that the emission reductions that have been credited are permanent. This terms is mainly used in relation to the permanence of REDD (Mainly used in relation to the permanence of REDD).

\section{LULUCF}

Acronym for Land Use, Land-Use Change and Forestry. See also AFOLU.

\section{Mitigation}

Actions to prevent further accumulation of GHG in the atmosphere by reducing the amounts emitted, or by increasing the storage of carbon in sinks.

\section{Nested approach}

A hybrid approach that includes elements of both subnational and national approaches to REDD. See Chapter 4 for further description.

\section{Output-based payments}

Output-based payments are payments directly conditional on outcomes. Two types of output-based measures are being discussed in the REDD debate: emissions-based and stock-based. The emissions-based (or flowbased) approach, measures and credits only the net changes in carbon stocks over time (emissions). The stock-based approach makes payments a function of the total carbon stock in the forest at any one time (i.e., absolute levels, and not changes).

\section{Payments for environmental (ecosystem) services (PES)}

Voluntary payment by a (minimum one) buyer to a (minimum one) provider to 'buy' an environmental service (or a land use likely to secure that service), if, and only if the provider secures the environmental service.

\section{Peatlands}

Wetlands where the soil is highly organic because it is formed mostly from partly decomposed plants.

\section{Permanence}

The duration and non-reversibility of a reduction in GHG emissions. Non-permanence can be seen as a form of intertemporal leakage. 


\section{Reduced impact logging (RIL)}

Intensively planned and carefully controlled harvesting to minimise the impact of logging on residual forest stands and soils, usually by selecting individual trees for felling.

\section{Reducing emissions from deforestation and forest degradation (REDD)}

REDD refers to mechanisms currently being negotiated under the UNFCCC process to reduce emissions from deforestation and forest degradation. REDD may refer to a broad set of approaches and actions that will achieve this, but the core idea is to create performance-based mechanisms that reward projects or countries that produce emission reductions.

\section{Reference level/line}

Commonly used in the sense of crediting baseline (See 'baseline').

\section{Reforestation}

Reforestation is 'the direct human-induced conversion of non-forested land to forested land through planting, seeding and/or the humaninduced promotion of natural seed sources, on land that was forested, but that has been converted to non-forested land'. In the first commitment period of the Kyoto Protocol, reforestation activities have been defined as reforestation of lands that were not forested on 31 December 1989, but have had forest cover at some point during the past 50 years.

\section{Remote sensing}

A method of measuring deforestation and/or forest degradation by a recording device that is not in physical contact with the forest, such as a satellite.

\section{Revegetation}

The growth of new vegetation on an area that has previously been cleared.

\section{Reverse leakage}

A mitigation activity that results in emissions reductions in areas outside the original mitigation area. Also referred to as 'positive leakage'.

\section{Stern Report/Review}

The Stern Review on the Economics of Climate Change is a 700-page report commissioned by the British government. The Review, by the economist Lord Stern of Brentford, was released on 30 October 2006 and discusses the effect of climate change and global warming on the world economy. The review concludes that $1 \%$ of global gross domestic product (GDP) per annum needs to be invested in order to avoid the worst effects of climate change. Failure to do so could risk lowering global GDP by $20 \%$. 


\section{Verification}

Independent third party assessment of the expected or actual emission reductions of a particular mitigation activity.

\section{Voluntary Carbon Standards}

Certification schemes for emission credits not regulated under the Kyoto Protocol.

\section{Wetlands}

Lands at the interface between terrestrial and aquatic ecosystems. They are characterised by standing water for at least part of the year. 


\section{References}

Achard, F., Belward, A.S., Eva, H.D., Federici, S., Mollicone, D. and Raes, F. 2005 Accounting for avoided conversion of intact and non-intact forests. Technical options and a proposal for a policy tool. Joint Research Centre of the European Commission.

Achard, F., DeFries, R., Herold, M., Mollicone, D., Pandey, D. and de Souza, C. 2008 Guidance on monitoring of gross changes in forest area. Chapter 3 In: GOFC-GOLD. Reducing greenhouse gas emissions from deforestation and degradation in developing countries: a sourcebook of methods and procedures for monitoring, measuring and reporting. GOFCGOLD Report version COP 13-2. GOFC-GOLD Project Office, Natural Resources Canada, Alberta, Canada.

Alvarado, L., Rubio, X. and Wertz-Kanounnikoff, S. 2007 Why are we seeing 'REDD'? An analysis of the international debate on reducing emissions from deforestation and degradation in developing countries. Institut du Développement Durable et des Relations Internationales (IDDRI), Paris.

Angelsen, A., and Kaimowitz, D. 1999 Rethinking the causes of deforestation: Lessons from economic models. World Bank Research Observer 14 (1): 73-98.

Angelsen, A. 2007 Forest cover change in space and time: Combining von Thünen and the forest transition. World Bank Policy Research Working Paper 4117. World Bank, Washington, D.C.

Anger, N. and Sathaye, J. 2008 Reducing deforestation and trading emissions: Economic implications for the post-Kyoto market. Discussion Paper No. 08-016. Center for European Economic Research, Mannheim, Germany.

Asner, G.P., Knapp, D.E., Broadbent, E.N., Oliveira, P.J.C., Keller, M. and Silva, J.N. 2005 Selective logging in the Brazilian Amazon. Science 310 (5747): 480-482.

Aukland, L., Costa, P.M. and Brown, S. 2003 A conceptual framework and its application for addressing leakage: the case of avoided deforestation. Climate Policy 3 (2): 123-136.

Blanco, J. and Forner, C. 2000 Special considerations regarding the 'expiring CERs' proposal. International Forum on Enhancement of Japan's Private Sector's Overseas Re-afforestation Cooperation, Ministerio del Medio Ambiente de Colombia, Bogotá, Colombia. 
Börner, J. and Wunder, S. 2008 Paying for avoided deforestation in the Brazilian Amazon: From cost assessment to scheme design. International Forestry Review 10 (3): 496-511.

Balmford, A. and Whitten, T. 2003 Who should pay for tropical conservation, and how could the costs be met? Oryx 37 (2): 238-250.

Brown, D. and Peskett, L. 2008 International forest policy: Integrated climate and forestry policy options. Policy Department A: Economic and Scientific Policy, DG Internal Policies, European Parliament, Brussels.

Brown, K., Adger, W.N., Boyd, E., Corbera-Elizalde, E. and Shackley, S. 2004 How do CDM projects contribute to sustainable development? Tyndall Centre Technical Report No. 16. Tyndall Centre, Norwich. http://www.tyndall.ac.uk/research/theme2/final_reports/it1_13.pdf (25 Nov. 2008).

Brown, S., Hall, M., Andrasko, K., Ruiz, F., Marzoli, W., Guerrero, G., Masera, O., Dushku, A., de Jong, B. and Cornell, J. 2007 Baselines for land-use change in the tropics: Application to avoided deforestation projects. Mitigation and Adaptation Strategies for Global Change 12 (6): 1001-1026.

Brown, S. and Braatz, B. 2008 Methods for estimating CO2 emissions from deforestation and forest degradation. Chapter $5 \mathrm{In}$ : GOFC-GOLD. Reducing greenhouse gas emissions from deforestation and degradation in developing countries: a sourcebook of methods and procedures for monitoring, measuring and reporting. GOFC-GOLD Report version COP 13-2. GOFC-GOLD Project Office, Natural Resources Canada, Alberta, Canada.

Bruijnzeel, L.A. 2004 Hydrological functions of tropical forests: not seeing the soil for the trees? Agriculture, Ecosystems \& Environment 104 (1): 185-228.

Byron, N. and Arnold, M. 1999 What future for the peoples of the tropical forests? World Development 27 (5):789-805.

Chave, J., Andalo, C., Brown, S., Cairns, M.A., Chambers, J.Q., Eamus, D., Fölster, H., Fromard, F., Higuchi, N., Kira, T., Lescure, J.P., Nelson, B.W., Ogawa, H., Puig, H., Riéra, B. and Yamakura, T. 2005 Tree allometry and improved estimation of carbon stocks and balance in tropical forests. Oecologia 145 (1): 87-99.

Chomitz, K.M. 2000 Evaluating carbon offsets from forestry and energy projects: How do they compare? World Bank Policy Research Working Paper No. 2357. World Bank, Washington, DC.

Chomitz, K.M., Buys P., de Luca, G., Thomas, T.S. and Wertz-Kanounnikoff, S. 2006 At loggerheads? Agricultural expansion, poverty reduction, and environment in the tropical forests. Policy Research Report. World Bank. Washington. DC. http://go.worldbank.org/KVK3ZDK510 (26 Nov. 2008). 
CISDL (Centre for International Sustainable Development Law) and GPPI (Global Public Policy Institute) 2007 A carbon stock approach to creating a positive incentive to reduce emissions from deforestation and forest degradation. Joint submission to the UNFCCC on reducing emissions from deforestation in developing countries. 23 February.

Colfer, C.J.P. and Capistrano, D. (eds.) 2005 The politics of decentralization: Forests, power, and people. Earthscan, London.

Colchester, M. 2008 Beyond tenure: Rights-based approaches to peoples and forest areas: Some lessons from the Forest Peoples Programme. FPP and RRI: Moreton-in-Marsh.

Colchester, M. and Ferrari, M. 2007 Making FPIC work: Challenges and prospects for indigenous peoples. FPIC Working Papers, Forest Peoples Program.

Convention on Biological Diversity, 1760 UNTS 79; 31 ILM 818 (1992).

Convention concerning Indigenous and Tribal Peoples in Independent Countries (ILO No. 169), 72 ILO Official Bull. 59; 28 ILM 1382 (1989).

Convention on Elimination of All Forms of Discrimination Against Women, GA Res. 34/180, 34 UN GAOR Supp. (No. 46) at 193, UN Doc. A/34/46; 1249 UNTS 13; 19 ILM 33 (1980).

Corbera, E. 2005 Bringing development into carbon forestry markets: Challenges and outcomes of small-scale carbon forestry activities in Mexico. In: Murdiyarso, D. and Herawati, H. (eds.) Carbon Forestry: Who will benefit? p. 42-56. CIFOR, Bogor, Indonesia.

Correa, R. and Moreno, L. 2007 Keeping ITT crude underground: the proposal. Ministry of External Affairs, Commerce and Integration, Quito.

Cosbey, A., Murphy, D., Drexhage, J. and Balint, J. 2006 Making development work in the CDM: Phase II of the Development Dividend Project. IISD, Winnipeg, Canada.

da Fonseca, G.A.B., Rodríguez, C.M., Midgley, G., Busch, J., Hannah, L. and Mittermeier, R.A. 2007 No forest left behind. PLoS Biology 5 (8): 1645-1646.

Decision 1/CP.13. Bali Action Plan, FCCC/CP/2007/6/Add.1.

Decision 2/CP.13. Reducing emissions from deforestation in developing countries: approaches to stimulate action, FCCC/CP/2007/6/Add.1.

DeFries, R., Achard, F., Brown, S., Herold, M., Murdiyarso, D., Schlamadinger, B. and de Sourza Jr., C. 2006. Reducing greenhouse gas emissions from deforestation in developing countries: Considerations for monitoring and measuring. Global Terrestrial Observing System (GTOS), Rome.

DeFries, R., Achard, F., Brown, S., Herold, M., Murdiyarso, D., Schlamadinger B. and de Souza, C. Jr. 2007 Earth observations for estimating greenhouse gas emissions from deforestation in developing countries. Environmental Science and Policy 10 (4): 385-394. 
de Jong, B., Bazán, E.E. and Montalvo, S.Q. 2007 Application of the 'Climafor' baseline to determine leakage: the case of Scolel Té. Mitigation and Adaptation Strategies for Global Change 12 (6): 1153-1168.

Dutschke, M. 2002 Fractions of permanence - Squaring the cycle of sink carbon accounting. Mitigation and Adaptation Strategies for Global Change 7 (4): 381-402.

Dutschke, M. 2007 CDM forestry and the ultimate objective of the Climate Convention. Mitigation and Adaptation Strategies for Global Change 12 (2): 275-302.

Dutschke, M. 2008 The climate stabilization fund - Global auctioning of emission allowances to help forests and people. Climate 2008/Klima 2008, Scientific Online Climate Conference. www.climate2008.net (25 Nov. 2008).

Dutschke, M. and Michaelowa, A. 2006 Development assistance and the CDM - how to interpret 'financial additionality'. Environment and Development Economics 11 (2): 235-246.

Dutschke, M. and Wolf, R. 2007 Reducing emissions from deforestation in developing countries. The way forward. GTZ Climate Protection Programme, Eschborn, Germany. 29p.

Ebeling, J. and Yasue, M. 2008 Generating carbon finance through avoided deforestation and its potential to create climatic, conservation and human development benefits. Philosophical Transactions of the Royal Society for Biological Sciences B, 363 (1498): 1917-1924.

ECJRC (European Commission Joint Research Centre) 2003 The global land cover map for the year 2000. GLC2000 database, European Commission Joint Research Centre.

EC (European Commission) 2008 Addressing the challenges of deforestation and forest degradation to tackle climate change and biodiversity loss. Communication from the Commission to the European Parliament, The Council, The European Economic and Social Committee and the Committee of the Regions. Com (2008) 645/3. Brussels.

Eggleston, S. 2008 Overview of relevant methodologies in IPCC Guidelines and Good Practice Guidance. Presentation at the UNFCCC workshop on Methodological Issues relating to Reducing Emissions from Deforestation and Forest Degradation in Developing Countries. Tokyo, 24-27 June. http://unfccc.int/files/methods_and_science/lulucf/application/ pdf/080625_tokyo_eggleson_ipcc.pdf (25 Nov. 2008).

Eliasch J. 2008 Eliasch Review - Climate change: Financing global forests. UK Office of Climate Change www.occ.gov.uk/activities/eliasch.htm (25 Nov. 2008).

Enkvist, P.A., Nauclér, T. and Rosander, J. 2007 A cost curve for greenhouse gas reduction. McKinsey Quarterly 2007 (1): 35-45. 
Euroactiv 2008 Brussels pushing for forests in global climate deal. Euroactiv, 20 October, Brussels, Belgium. http://www.euractiv.com/en/ environment/brussels-pushing-forests-global-climate-deal/article-176474 25 Nov. 2008).

Fearnside, P.M. 2000 Uncertainty in land use change and forestry sector mitigation options for global warming: Plantation silviculture versus avoided deforestation. Biomass and Bioenergy 18 (6): 457-468.

Fearnside, P.M., Lashof, D.A. and Moura-Costa, P. 2000 Accounting for time in mitigating global warming through land-use change and forestry. Mitigation and Adaptation Strategies for Global Change 5 (3): 239-270.

Fearnside, P.M. 2002 Time preference in global warming calculations: a proposal for a unified index. Ecological Economics 41 (1): 21-31.

Fischlin, A., Midgley, G.F. 2007 Ecosystems, their properties, goods, and services. In: Parry, M.L., Canziani, O.F., Palutikof, J.P., van der Linden, P.J. and Hanson, C.E. (eds.) Climate change 2007: Impacts, adaptation and vulnerability. Contribution of Working Group II to the Fourth Assessment Report of the Intergovernmental Panel on Climate Change, 211-272. Cambridge University Press, Cambridge.

Fisher, B., Nakicenovic, N., Alfsen, K., Corfee Morlot, J., de la Chesnaye, F., Hourcade, J-C., Jiang, K., Kainuma, M., La Rovere, E., Matysek, A., Rana, A., Riahi, K. Richels, R., Rose S. and van Vuuren, D., Warren, R. 2007 Issues related to mitigation in the long term context. In: Metz, B., Davidson, O.R., Bosch, P.R., Dave, R. and Meyer, L.A. (eds.) Climate change 2007: Mitigation of climate change. Contribution of Working Group III to the Fourth Assessment Report of the Inter-governmental Panel on Climate Change, Cambridge University Press, Cambridge, UK.

Foti, J., de Silva, L., Werksman, J., Shaffer, L., Talbot, J. and McGray, H. 2008 Voice and choice: Opening the door to environmental democracy. World Resources Institute.

Gan, J. and McCarl, B. 2007 Measuring transnational leakage of forest conservation. Ecological Economics 64 (2): 423-432.

Gibbs, H.K., Brown, S., O’Niles, J. and Foley, J.A. 2007 Monitoring and estimating forest carbon stocks: Making REDD a reality. Environmental Resource Letters 2 (2007): 045023 (13pp).

GOFC-GOLD 2008 Reducing greenhouse gas emissions from deforestation and degradation in developing countries: a sourcebook of methods and procedures for monitoring, measuring and reporting, GOFC-GOLD Report version COP 13-2. GOFC-GOLD Project Office, Natural Resources Canada, Alberta, Canada.

Grieg-Gran, M. 2008 The cost of avoiding deforestation. IIED, London: 20. http://www.iied.org/pubs/pdfs/G02290.pdf (25 Nov. 2008).

Hamilton, K., Bayon, R., Turner, G. and Higgins, D. 2007 State of the voluntary carbon markets 2007: Picking up steam. The Ecosystem Marketplace and New Carbon Finance, Washington, DC. 
Hamilton, K., Sjardin, M., Marcello, T. and Xu, G. 2008 Forging a frontier: State of the voluntary carbon markets 2008. Ecosystem Market Place and New Carbon Finance, San Francisco and London.

Hansen, M.C., Stehman, S.V., Potapov, P.V., Loveland, T.R., Townshed, J.R.G., DeFries, R.S., Pittman, K.W., Arunarwati, B., Stolle, F., Steininger, M.K., Carroll, M. and DiMiceli, C. 2008 Humid tropical forest clearing from 2000 to 2005 quantified by using multitemporal and multiresolution remotely sensed data. PNAS 105 (27): 9439-9444.

Hardcastle, P.D. and Baird, D. 2008 Capability and cost assessment of the major forest nations to measure and monitor their forest carbon. Office of Climate Change. LTS International, Penicuick, UK. http://www.occ.gov. uk/activities/eliasch.htm (25 Nov. 2008).

Hare, B. and Macey, K. 2007 Tropical deforestation emission reduction mechanism (TDERM): A discussion paper. Greenpeace International, Amsterdam, Netherlands. 52p. http://www.greenpeace.org/raw/content/ international/press/reports/TDERM-full.pdf (25 Nov. 2008).

Hoare, A., Legge, T., Nussbaum, R. and Saunders, J. 2008 Estimating the cost of building capacity in rainforest nations to allow them to participate in a global REDD mechanism. Chatham House and ProForest, UK. http://www.occ.gov.uk/activities/eliasch/Chatham_House_cost_of_ building_capacity.pdf (25 Nov. 2008).

Hughes, R. and Flintan, F. 2001 Integrating conservation and development experience: a review and bibliography of the ICDP literature. International Institute for Environment and Development, London, UK. 24p. http://www.ucc.ie/famine/GCD/ICDP_sec.pdf (25 Nov. 2008).

INPE 2004 Monitoramento ambiental da Amazonia por satelite. Brazilian Institute for Space Research. http:/www.obt.inpe.br/prodes/ (25 Nov. 2008).

International Covenant on Economic, Social and Cultural Rights, GA Res. 2200A (XXI), 21 UN GAOR Supp. (No. 16) at 49, UN Doc. A/6316 (1966); 993 UNTS 3; 6 ILM 368 (1967).

International Covenant on Civil and Political Rights, GA Res. 2200A (XXI), 21 UN GAOR Supp. (No. 16) at 52, UN Doc. A/6316 (1966); 999 UNTS 171; 6 ILM 368 (1967).

IPCC (Intergovernmental Panel on Climate Change) 2003 Good practice guidance on land use, land-use change and forestry, prepared by the National Greenhouse Gas Inventories Programme. Eggleston, H.S., Buendia, L., Miwa, K., Ngara, T. and Tanabe, K. (eds.). Institute for Global Environmental Strategies (IGES), Japan.

IPCC 2003a Definitions and methodological options to inventory emissions from direct human-induced degradation of forests and devegetation of other vegetation types. Penman, J., Gytarsky, M., Krug, T., Kruger, D., Pipatti, R., Buendia, L., Miwa, K., Ngara, T., Tanabe, K. and Wagner, F. (eds.), IPCC-IGES, Kanagawa. 
IPCC 2003b Good practice guidance for land use, land-use change and forestry (GPG-LULUCF). Penman, J., Gytarsky, M., Krug, T., Kruger, D., Pipatti, R., Buendia, L., Miwa, K., Ngara, T., Tanabe, K. and Wagner, F. (eds.), IPCC-IGES, Kanagawa. http://www.ipcc-nggip.iges.or.jp/public/ gpglulucf/gpglulucf_contents.html (25 Nov. 2008).

IPCC 2006 IPCC Guidelines for national greenhouse gas inventories, prepared by the National Greenhouse Gas Inventories Programme. Eggleston, H.S., Buendia, L., Miwa, K., Ngara, T. and Tanabe, K. (eds.). Institute for Global Environmental Strategies (IGES), Japan. http://www.ipcc-nggip.iges.or.jp/ public/2006gl/index.html (25 Nov. 2008).

IPCC 2006 Guidelines for national greenhouse gas inventories - volume 4: Agriculture, land use and forestry (GL-AFOLU). http://www.ipcc-nggip. iges.or.jp/public/2006gl/vol4.html (25 Nov. 2008).

Iskandar, H., Snook, L., Toma, T., MacDicken, K. and Kanninen, M. 2006 A comparison of damage due to logging under different forms of resource access in East Kalimantan, Indonesia. Forest Ecology and Management 237 (1-3): 83-93.

Jakeman, G. and Fisher, B.S. 2006 Benefits of multi-gas mitigation: an application of the Global Trade and Environment Model (GTEM), multigas mitigation and climate policy. The Energy Journal 27 (3): 323-342.

Kanowski, J.J., Catterall, C. and Wardell-Johnson, G.W. 2005 Consequences of broadscale timber plantations for biodiversity in cleared rainforest landscapes of tropical and subtropical Australia. Forest Ecology and Management 208 (1-3): 359-372.

Karousakis, K. 2007 Incentives to reducing emissions from deforestation: Lessons learned from Costa Rica and Mexico. OECD, Paris. 50p.

Khan, M. 2006 State failure in developing countries and strategies of institutional reform. http://www.gdnet.org/pdf2/online_journals/cerdi/ issue2_3/Khan_paper1.pdf (25 Nov. 2008).

Kindermann, G., Obersteiner, M., Sohngen, B., Sathaye, J., Andrasko, K., Ramesteiner, E., Schlamadinger, B., Wunder, S. and Beach, R. 2008 Global cost estimates of reducing carbon emissions through avoided deforestation. Proceedings of the National Academy of Sciences 105 (30): 10302-10307.

Korhonen L., Korhonen, K.T., Rautiainen, M. and Stenberg, P. 2006 Estimation of forest canopy cover: a comparison of field measurement techniques. Silva Fennica 40 (4): 577-588. www.metla.fi/silvafennica/full/ sf40/sf404577.pdf (25 Nov. 2008).

Kurosawa, A. 2006 Multi-gas mitigation: an economic: analysis using the GRAPE model. The Energy Journal 27 (3): 275-288.

Lambin, E.F., Geist, H.J. and Lepers, E. 2003 Dynamics of land-use and land-cover change in tropical regions. Annual Review of Environmental Resources 28: 205-241.

Larson, A. and Ribot, J. 2007 The poverty of forestry policy: Double standards on an uneven playing field. Sustainability Science 2 (2): 189-204. 
Leach, P. 2008 Carbon sunk? The potential impacts of avoided deforestation credits on emissions trading mechanisms. The Rainforest Foundation, London. http://www.rainforestfoundationuk.org/Carbon_Sunk (25 Nov. 2008).

Lecocq, F. and Chomitz, K.M. 2001 Optimal use of carbon sequestration in a global climate change strategy: Is there a wooden bridge to a clean energy future? World Bank Development Research Group Infrastructure and Environment, Washington, DC.

Marklund, L.G. and Schoene, D. 2006 Global assessment of growing stock, biomass and carbon stock. Forest Resources Assessment Programme Working paper 106/E, Rome.

Massai, L. 2007 European Climate Policy Dossier. T.M.C. Asser Institute, The Hague, NL. 57p.

Mather, A. 1992 The Forest Transition. Area 24 (4): 367-379.

M-Co Consulting 2008 Review and assessment of options for reducing emissions from deforestation in developing countries. Government of New Zealand, Ministry of Agriculture and Forestry, Wellington.

Meijaard, E., Sheil, D., Nasi, R., Augeri, D., Rosenbaum, B., Iskandar, D., Setyawati, T., Lammertink, M., Rachmatika, I., Wong, A., Soehartono, T., Stanley, S. And O'Brien, T. 2005 Life after logging: Reconciling wildlife conservation and production forestry in Indonesian Borneo. CIFOR, Bogor, Indonesia. http://www.cifor.cgiar.org/publications/pdf_files/books/ BMeijaard0501E0.pdf (25 Nov. 2008).

Miles, L., Kapos, V., Lysenko, I. and Campbell, A. 2008 Mapping vulnerability of tropical forest to conversion, and resulting $\mathrm{CO} 2$ emissions: A rapid assessment for the Eliasch review. UNEP World Conservation Monitoring Centre. http://www.occ.gov.uk/activities/eliasch/UNEP_WCMC_ mapping_vulnerability_of_tropical_forest(1).pdf (25 Nov. 2008).

Mollicone, D., Achard, F., Federici, S., Eva, H.D., Grassi, G., Belward, A., Raes, F., Seufert, G., Stibig, H.J., Matteucci, G. and Schulze E.D. 2007 An incentive mechanism for reducing emissions from conversion of intact to non-intact forests. Climate Change 83 (4): 477-493.

Motel, P.C., Pirard, R. and Combes, J.L. 2008 A methodology to estimate impacts of domestic policies on deforestation: Compensated successful efforts for 'avoided deforestation' (REDD). Ecological Economics (forthcoming).

Moura-Costa, P. and Wilson, C. 2000 An equivalence factor between CO2 avoided emissions and sequestration: Description and applications in forestry. Mitigation and Adaptation Strategies for Global Change 5 (1): 51-60.

Muller, A. 2007 How to make the clean development mechanism sustainable - the potential of rent extraction. Energy Policy 35 (6): 3203-3212.

Murphy, P.G. and Lugo, A.E. 1986 Ecology of tropical dry forest. Annual Review of Ecology and Systematics 17: 67-68. 
Murray, B.C. 2008 Leakage from an avoided deforestation compensation policy: Concepts, empirical evidence, and corrective policy options. Nicholas Institute for Environmental Policy Solutions, Duke University, Durham, NC. 32p.

Nepstad, D. 2007 The Amazon's vicious cycles: Drought and fire in the greenhouse. WWF Report. http://assets.panda.org/downloads/amazonas_ eng_04_12b_web.pdf (25 Nov. 2008).

Nepstad, D., Soares-Filho, B., Merry, F., Moutinho, P., Oliveira Rodrigues, H., Bowman, M., Schwartzman, S., Almeida, O. and Rivero, S. 2007 The costs and benefits of reducing deforestation in the Brazilian Amazon. The Woods Hole Research Center, Woods Hole, MA.

Obersteiner M., Azar Ch., Kauppi P., Möllersten K., Moreira J., Nilsson S., Read P., Riahi K., Schlamadinger B., Yamagata Y., Yan J. and van Ypersele J.-P. 2001. Managing climate risk. Science 294 (5543): 786-787.

OECD (Office of Economic Co-operation and Development) 2005 Paris declaration on aid effectiveness: Ownership, harmonisation, alignment, results and mutual accountability. OECD, Paris. www.oecd.org/ dataoecd/11/41/34428351.pdf (25 Nov. 2008).

Ogonowski, M., Helme, N., Movius, D. and Schmidt, J. 2007 Reducing emissions from deforestation and degradation: The dual markets approach. International Future Action Dialogue. Center for Clean Air Policy, Washington, DC.

Olander, L.P., Gibbs, H.K., Steininger, M., Swenson, J.J. and Murray, B.C. 2008 Reference scenarios for deforestation and forest degradation in support of REDD: a review of data and methods. Environmental Research Letters 3 (2008): 025011. http://www.iop.org/EJ/article/1748-9326/3/2/025011/ erl8_2_025011.pdf (25 Nov. 2008).

Pearce, F. 2007 Save the climate by saving the forest. New Scientist, 22 March 2008.

Pearson T., Harris N., Shock D., Pandey D. and S. Brown. 2008. Estimation of carbon stocks. Chapter 4 in: GOFC-GOLD. Reducing greenhouse gas emissions from deforestation and degradation in developing countries: a sourcebook of methods and procedures for monitoring, measuring and reporting, GOFC-GOLD Report version COP13-2, GOFC-GOLD Project Office, Natural Resources Canada, Alberta, Canada.

Pedroni, L., Streck, C., Estrada, M. and Dutschke, M. 2007 The 'Nested Approach': A flexible mechanism to reduce emissions from deforestation. CATIE, Turrialba, Costa Rica.

Penman, J., Gytarsky, M., Hiraishi, T., Krug, T., Kruger, D., Pipatti, R., Buendia, L., Miwa, K., Ngara, T., Tanabe, K. and Wagner, F. 2003 Good practice guidance for land use, land-use change and forestry. IPCC National Greenhouse Gas Inventories Programme and Institute for Global Environmental Strategies (IGES), Kanagawa, Japan. Intergovernmental Panel on Climate Change. http://www.ipcc-nggip.iges.or.jp/public/ gpglulucf/gpglulucf_contents.htm (25 Nov. 2008). 
Penman, J. 2008 An exploration by the EU on methodological issues relating to reducing emissions from forest degradation in developing countries. UNFCCC Informal Meeting of Experts, Bonn, 20-21 October 2008. http://unfccc.int/methods_science/redd/items/4579.php (25 Nov. 2008).

Peskett, L., Huberman, D., Bowen-Jones, E., Edwards, G. and Brown, J. 2008 Making REDD work for the poor. IUCN/ODI for the Poverty and Environment Partnership, Gland.

Petley, S. 2007 Forest backed securities: Alternative finance for tropical natural forest. Presentation to the Asia-Pacific Tropical Forest Investment Forum, August, 2007. www.itto.or.jp/live/Live_Server/3289/ PetleyITTOBangkokREV.JG.pdf (25 Nov. 2008).

Piris-Cabezas, P. and Keohane, N. 2008 Reducing emissions from deforestation and degradation in developing countries (REDD): Implications for the carbon market. Environmental Defense Fund, Washington, DC. 13p. http://www.climaedesmatamento.org.br/files/general/EDF_Analysis_of_ REDD_in_the_carbon_market_061808.pdf (25 Nov. 2008).

Rao, S. and Riahi, K. 2006 The role of non-CO2 greenhouse gases in climate change mitigation: Long-term scenarios for the $21^{\text {st }}$ Century, multi-gas mitigation and climate policy. Energy Journal 27 (3): 177-200.

Riahi, K., Grubler, A. and Nakicenovic, N. 2006 Scenarios of long-term socioeconomic and environmental development under climate stabilisation. Technological Forecasting and Change 74: 8-9.

Rights and Resources Initiative, 2008. Foundations for effectiveness. Policy brief prepared by RRI and RFN in preparation for the International Conference on Rights, Forests and Climate Change, Oslo, October 15-17, 2008.

Rio Declaration, UN Doc. A/CONF.151/26 (Vol. I); 31 ILM 874 (1992).

Robertson, N. and Wunder, S. 2005 Fresh tracks in the forest: Assessing incipient payments for environmental services initiatives in Bolivia. CIFOR, Bogor, Indonesia. 137p. http://www.cifor.cgiar.org/pes/publications/pdf_files/ BRobertson0501.pdf (25 Nov. 2008).

Rose, S., Helal, A., Eickhout, B., Fisher, B., Kurosawa, A., Rao, S., Riahi, K. and van Vuuren, D. 2007 Land in climate stabilization modeling: Initial observations. Energy Modeling Forum Report, Stanford University.

Roy, D.P., Jin, Y., Lewis, P.E. and Justice, C.O. 2005 Prototyping a global algorithm for systematic fire-affected area mapping using MODIS timeseries data. Remote Sensing of Environment 97 (2): 137-162.

Rudel, T.K., Coomes, O.T, Moran, E., Achard, F., Angelsen, A., Jianchu Xu and Lambin, E. 2005 Forest transitions: Towards a global understanding of land use change. Global Environmental Change 15 (1): 23-31.

Santilli, M., Moutinho, P., Schwartzman, S., Nepstad, D., Curran, L. and Nobre, C. 2005 Tropical deforestation and the Kyoto Protocol. Climatic Change 71 (3): 267-276. 
Sathaye, J. and Andrasko, K. 2007 Special issue on estimation of baselines and leakage in carbon mitigation forestry projects. Mitigation and Adaptation Strategies for Global Change 12 (6): 963-970.

Schelhas, J. and Sanchez-Azofeifa, G.A. 2006 Post-frontier forest change adjacent to Braulio Carrillo National Park, Costa Rica. Human Ecology 34 (3): 407-431.

Schlamadinger, B., Ciccarese, L., Dutschke, M., Fearnside, P.M., Brown, S. and Murdiyarso, D. 2005 Should we include avoidance of deforestation in the international response to climate change? In: Carbon forestry: Who will benefit? Murdiyarso, D. and Herawati, H. (eds.) CIFOR, Bogor, Indonesia.

Schlamadinger, B. and Johns, T. 2006 Reducing emissions from deforestation and forest degradation: Latest developments. Climate Change Mitigation Measures in the Agro-Forestry Sector and Biodiversity Futures, Trieste / IT, ICTP.

Schlamadinger, B., Bird, N., Johns, T., Brown, S., Canadell, J. Ciccarese, L., Dutschke, M., Fiedler, J., Fischlin, A., Fearnside, P., Forner, C., Freibauer, A., Frumhoff, P., Hoehne, N., Kirschbaum, M.U.F., Labat, A., Michaelowa, A., Montanarella, L., Moutinho, P. Murdiyarso, D., Pena, N., Pingoud, K., Rakonczay, Z., Rametsteiner, E., Rock, J., Sanz, M.J., Schneider, U.A., Shvidenko, A., Skutsch, M., Smith, P., Somogyi, Z., Trines, E., Ward, M. and Yamagata, Y. 2007 A synopsis of land use, land-use change and forestry (LULUCF) under the Kyoto Protocol and Marrakech Accords. Environmental Science and Policy 10 (4): 271-282.

Scholz, I. and Schmidt, L. 2008 Reducing emissions from deforestation and forest degradation in developing countries: Meeting the main challenges ahead. German Development Institute (DIE) Briefing Paper (preliminary version). http://www.illegal-logging.info/uploads/GermanDevInstREDD. pdf (25 Nov. 2008).

Schwarze, R., Niles, J.O. and Olander, J. 2002 Understanding and managing leakage in forest-based greenhouse gas mitigation projects. TNC, Arlington.

Seymour, F. (forthcoming) Forests, climate change, and human rights: Managing risks and trade-offs. In: Humphreys, S. (ed.) Human rights and climate change. Cambridge University Press, Cambridge.

Skutsch, M. and Trines, E. 2008 Operationalising reduced degradation within REDD. Policy Paper No.2: Kyoto: Think Globally Act Locally project.http://www.communitycarbonforestry.org/resources_Pub08.htm (25 Nov. 2008).

Sohngen, B. and Brown, S. 2004 Measuring leakage from carbon projects in open economies: a stop timber harvesting project in Bolivia as a case study. Canadian Journal of Forestry Research 34 (4): 829-839.

Stern, N. 2006 Stern Review: The economics of climate change. Cambridge University Press, Cambridge, UK. 
Stern, N. 2008 Key elements of a global deal on climate change. London School of Economics and Political Science, London. 56p.

Strassburg, B., Turner, K., Fisher, B., Schaeffer, R. and Lovett, A. 2008 An empirically-derived mechanism of combined incentives to reduce emissions from deforestation. In: CSERGE Working Paper ECM 08-01. Centre for Social and Economic Research on the Global Environment (CSERGE), University of East Anglia, Norwich, UK.

Subak, S. 2003 Replacing carbon lost from forests: an assessment of insurance, reserves, and expiring credits. Climate Policy 3 (2): 107-122.

Sunderlin, W., Hatcher, J. and Liddle, M. 2008 From exclusion to ownership? Challenge and opportunities in advancing forest tenure reform. Rights and Resources Initiative, Washington, DC. http://www.rightsandresources.org/ documents/index.php?pubID=736 (25 Nov. 2008).

Tavoni, M., Sohngen, B. and Bosetti, V. 2007 Forestry and the carbon market response to stabilize climate. Energy Policy 35 (11): 5346-5353.

Terrestrial Carbon Group 2008 How to include terrestrial carbon in developing countries in the overall climate change solution. Draft, 8 August.

Ramsar Convention on Wetlands. Convention on Wetlands of International Importance especially as Waterfowl Habitat. Ramsar (Iran), 2 February 1971. UN Treaty Series No. 14583.

Trines, E., Höhne, N., Jung, M., Skutsch, M., Petsonk, A., Silva-Chavez, G., Smith, P., Nabuurs, G., Verweij and P. Schlamadinger, B. 2006 Integrating agriculture, forestry and other land use in future climate regimes. Methodological issues and policy options. Netherlands Environmental Assessment Agency, Bilthoven.

Tutin, C.E.G. and Fernandez, M. 1985 Foods consumed by sympatric populations of Gorilla g. gorilla and Pan t. troglodytes in Gabon: Some preliminary data. International Journal of Primatology 6 (1): 27-43.

Tuvalu (Government of) 2007 Submission from Tuvalu In: Reducing emissions from deforestation in developing countries: Approaches to stimulate action. Subsidiary Body for Scientific and Technologica Advice, Twenty-seventh session, Bali, 3-11 December 2007. http://unfccc.int/resource/docs/2007/ sbsta/eng/misc14a03.pdf (25 Nov. 2008).

Underdal, A. 2002 One question, two answers. In: Miles, E.L., Underdal, A., Andersen, S., Wettestad, J., Skærseth, J.B. and Carlin, E.M. (eds.) Environmental regime effectiveness. Confronting theory with evidence. MIT Press, Cambridge.

United Nations Declaration on the Rights of Indigenous Peoples, GA Res. 61/295, U.N. Doc. A/RES/61/295 (13 Sept. 2007), 46 I.L.M. 1013 (2007).

United Nations Forum on Forests (UNFF) Non-legally binding instrument on all types of forests, E/2007/42.

UN Convention on Access to Information, Public Participation in Decisionmaking and Access to Justice in Environmental Matters, 2161 UNTS 447; 38 ILM 517 (1999). 
United Nations Convention to Combat Desertification, 1954 UNTS 3; 33 ILM 1328 (1994).

UNFCCC 2007 Investment and financial flows to address climate change. UNFCCC, Bonn.

UNFCC 2007c Subsidiary Body for Scientific and Technological Advice, Twenty-seventh session, Bali, Indonesia, 3-11 December 2007.

UNFCCC 2008a Views on outstanding methodological issues related to policy approaches and positive incentives to reduce emissions from deforestation and forest degradation in developing countries. Advanced version. SBSTA Misc. for $28^{\text {th }}$ session. Bonn, 4-13 June.

UNFCCC 2008b Informal meeting of experts on methodological issues relating to reducing emissions from forest degradation in developing countries. Bonn, 20-21 October.

Universal Declaration of Human Rights, GA Res. 217A (III), U.N. Doc A/810 at 71 (1948).

Ward, M., CWard, M., Strect, C., Winkler, H. Jung, M., Hagemann, M., Höhne, N., and O'Sullivan , R. 2008 The role of sector no-lose targets in scaling up finance for climate change mitigation activities in developing countries. International Climate Division, Dept. of Environment, Food and Rural Affairs (DERFA), United Kingdom.

Watson, R.T., Intergovernmental Panel on Climate Change, Noble, I.R., Bolin, B. 2000 Land use, land-use change, and forestry: A special report of the Intergovernmental Panel on Climate Change. Cambridge University Press, Cambridge, UK. 377p.

Wertz-Kanounnikoff, S. 2008 Cost-effective methods for monitoring forest cover changes and associated $\mathrm{CO}_{2}$ emissions for REDD. CIFOR, Bogor, Indonesia, International Institute for Environment and Development (IIED), London, UK and World Resources Institute (WRI), Washington, D.C., USA.

WHRC (Woods Hole Research Center) and IPAM (Instituto de Pesquisa Ambiental da Amazonia) 2008 How to distribute REDD funds across countries? A stock-flow mechanism. Joint submission to the UNFCCC regarding AWG-LCA (FCCC/AWGLCA/2008/L.7), 30 September.

Winrock. 2002 Analysis of leakage, baselines, and carbon benefits for the Noel Kempff Climate Action Project. 45. Ecosecurities Ltd., Sylvan Acres, Geographic Modelling Services.

Wittemyer, G., Elsen, P., Bean, W.T., Coleman, A., Burton, O. and Brashares, J.S. 2008 Accelerated human population growth at protected area edges. Science 321 (5885): 123-126.

Wong, J. and Dutschke, M. 2003 Can permanence be insured? Consideration of some technical and practical issues of insuring carbon credits from afforestation and reforestation. HWWA Discussion Paper 235. 17p.

World Bank 2004 Sustaining forests: A development strategy. World Bank, Washington,DC. http://siteresources.worldbank.org/INTFORESTS/ Resources/SustainingForests.pdf (25 Nov. 2008). 
World Bank 2008 Climate investment funds: Mapping of existing and emerging sources of forest financing (CIF/FDM.1/2, October 7, 2008). First design meeting on the forest investment program, Washington, DC, October 16-17. http://siteresources.worldbank.org/INTCC/Resources/ Mapping_study_Final_for_FIP_Design_Meeting_Oct_16-17_08.pdf (25 Nov. 2008).

Wu, J.J. 2000 Slippage effects of the Conservation Reserve Program. American Journal of Agricultural Economics 82 (4): 979-992. 

REDD (reducing emissions from deforestation and forest degradation) is based on a simple idea: pay developing countries to reduce $\mathrm{CO}_{2}$ emissions from the forest sector. Nevertheless, design and implementation of a REDD system raise many hard questions: How are emissions reductions monitored, reported and verified? How should REDD be financed? Should payments be directed to countries, projects, or both? How should reference levels be set? How are non-permanence and leakage accounted? How to achieve REDD co-benefits and avoid doing harm?

Moving Ahead with REDD: Issues, Options and Implications does not attempt to give definite answers. Instead, the book presents design options for a global REDD architecture and reviews their implications on the $3 \mathrm{E}$ criteria - Effectiveness in reducing emissions, cost Efficiency, and Equity and co-benefits. Anyone involved in the REDD debate and negotiations can benefit from this clear and concise presentation of key REDD issues.

Contributors: A. Angelsen, S. Atmadja, D. Brown, J. Brown,

M. Dutschke, M. Guariguata, P. Guizol, M. Kanninen, R. Lubowski,

C. Luttrell, D. Murdiyarso, L. Peskett, F. Seymour, M. Skutsch,

O. Stella Martins, C. Streck, L.V. Verchot, P. Verweij,

S. Wertz-Kanounnikoff and S. Wunder

ISBN 978-979-14-1276-6

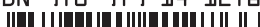

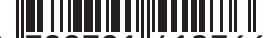

$91789791 \|_{412766}$

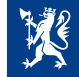

NORWEGIAN MINISTRY OF THE ENVIRONMENT

ENIION
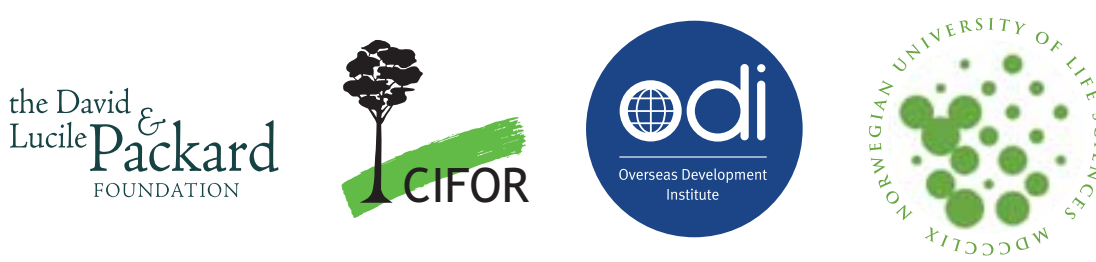

e bigarbon for climate consult
ENVIRONMENTAL DEFENSE FUND finding the ways that work 